Zabytkoznawstwo i Konserwatorstwo XXXIX, Toruń 2010

Wiesław Domasłowski

Uniwersytet Mikołaja Kopernika w Toruniu

\title{
Badania nad technologią zapraw imitujących kamienie naturalne Gotland i Obernkirchen
}

\section{Cel badań}

Ta zlecenie Deutsches Bergbau-Museum Zollern-Institut w Bochum 1 przeprowadzono badania ${ }^{1}$, których celem było opracowanie technologii zapraw o zbliżonych właściwościach fizykomechanicznych do piaskowców Gotland i Obernkirchen. Za najważniejsze uznano następujące właściwości zapraw:

- zbliżoną do wymienionych kamieni zdolność kapilarnego podciagania wody,

- zbliżoną lub mniejszą nasiąkliwość woda,

- zbliżoną lub niższą wytrzymałość na ściskanie,

- podobną strukturę i kolor,

- zbliżoną rozszerzalność cieplną,

- zbliżoną odporność na ścieranie.

Poza wymienionymi właściwościami zaprawy powinny mieć dobra plastyczność umożliwiającą łatwe nakładanie ich na kamienie i modelowanie, przyczepność w stanie niezwiązanym i po stwardnieniu, powinny być

1 Badania dotyczyły konserwacji fasady renesansowego ratusza w Lubece. Oprócz autora uczestniczyły w nich: prof. dr hab. Jadwiga Łukaszewicz (badania nad wzmacnianiem kamieni) i dr Maria Kessy-Lewandowska (badania nad hydrofobizacją kamieni). Badania były finansowane przez Niemiecką Fundację Ochrony Środowiska (DBU). 
odporne na działanie wody, soli, zamrażanie, zmienne warunki atmosferyczne i agresywne gazy. Wymienione właściwości zapraw stosowanych do uzupełniania ubytków w kamieniach sformułowano już we wcześniejszych pracach $^{2}$.

Do badań wykorzystano spoiwa mineralne (cementy portlandzkie, wapno hydratyzowane i dyspergowane) oraz organiczne (żywice epoksydową i polimetakrylan metylu). Spośród kruszyw wybrano piasek szklarski o granulacji zbliżonej (nieco wyższej) do ziaren piasku występujących w piaskowcach Gotland i Obernkirchen oraz zmielone piaskowce. Zaprawy modyfikowano dodatkami metakaolinitu, krzemionki koloidalnej, mączki kwarcowej i marmurowej. Zmieniając proporcję kruszywa do spoiwa, stosując zmienne ilości substancji modyfikujących, starano się uzyskać zaprawy o wymienionych powyżej cechach. Kryterium, którym kierowano się przede wszystkim, to właściwości kapilarne zapraw i ich wytrzymałość na ściskanie. Te dwie cechy decydują głównie o trwałości połączeń kamień-zaprawa. Zaprawa powinna mieć lepsze właściwości kapilarne od piaskowców, aby pełniła funkcję sączka ściaggającego z kamieni wodę, a w zasadzie roztwory soli. Zaprawa przejmuje $\mathrm{w}$ ten sposób rolę buforu zabezpieczającego kamienie zabytku przed zniszczeniem, jednocześnie sama mu ulegając. Aby zaprawy pełniły swą funkcję ochronna, ich wytrzymałość mechaniczna nie powinna być wyższa od wytrzymałości piaskowców. Słabsze zaprawy łatwiej będą ulegać zniszczeniu niż piaskowce w przypadku wahań temperatury (naprężenia ścinające, powstające w wyniku różnych współczynników rozszerzalności cieplnej zapraw i kamieni), zamarzania wody i działania soli rozpuszczalnych w wodzie. W przypadku „zdrowych” piaskowców Gotland i Obernkirchen taka ewentualność nie zachodzi, ponieważ ich wytrzymałość jest bardzo duża (tab. 1) i zapraw o takiej odporności, przy zachowaniu postulowanych właściwości fizycznych, praktycznie nie można otrzymać. Małą wytrzymałość mają natomiast zwykle zniszczone piaskowce i stosowane preparaty do wzmacniania mogą nie przywrócić im pierwotnych parametrów. Dlatego też ustalono, że wytrzymałość zapraw na ściskanie powinna być znacznie niższa

2 W. Domasłowski, Badania nad technologia materiałów do kitowania i rekonstrukcji kamiennych rzeźb i detali architektonicznych, „Zeszyty Naukowe Uniwersytetu Mikołaja Kopernika, Zabytkoznawstwo i Konserwatorstwo", 1966, t. 2, s. 83. 
od „zdrowych” piaskowców Gotland i Obernkirchen, lecz na tyle wysoka, aby nie ulegały one szybkiemu niszczeniu w środowisku naturalnym.

W tabeli 1 zestawiono właściwości piaskowców Gotland i Obernkirchen oraz postulowane właściwości zapraw przeznaczonych do uzupełniania ubytków w tych piaskowcach. Jak wynika z danych zamieszczonych w tabeli 1, zaprawy do uzupełniania ubytków w piaskowcu Gotland powinny po 6 godzinach nasycania kapilarnego wchłonąć ponad 95\% wody, a więc praktycznie być nią nasycone. Zaprawy dla piaskowca Obernkirchen powinny po 6 godzinach kapilarnego podciągania wody wykazywać minimum 70\% nasycenia, a po 24 godzinach 100\%. Wytrzymałość zapraw dla Gotlandu powinna mieścić się w granicach 15-20 MPa, a dla Obernkirchen 20-30 MPa. Należy podkreślić, że świadomie założono, że właściwości kapilarne zapraw do piaskowca Gotland będą nieco niższe od średnich właściwości, jakie stwierdzono, badając próbki „zdrowego” kamienia. Właściwości te będą raczej zbliżone do próbek o maksymalnym czasie podciągania wody. Decyzja taka wynika z niemożliwości uzyskania zapraw mineralnych o wysokich parametrach mechanicznych, dobrych właściwościach kapilarnych i jednocześnie niskiej nasiąkliwości jak w przypadku piaskowca Gotland. Wielkości te wykluczają się wzajemnie. Przy polepszaniu właściwości kapilarnych następuje gwałtowny spadek wytrzymałości mechanicznej zapraw i wzrasta nasiąkliwość. Dlatego też jesteśmy zmuszeni zgodzić się na kompromis i wybrać zaprawy nie o identycznych właściwościach, lecz zbliżonych do kamieni naturalnych.

\section{Materiały}

Do badań użyto białego cementu portlandzkiego CEM - 52,5 white produkcji Cementowni Wejherowo, szarego cementu portlandzkiego CEM I - 42,5 R NA produkcji KCW WARTA SA w Działoszynie, wapna hydratyzowanego produkcji Zakładów Cementowo-Wapiennych „Górażdże" w Choruli, żywicy epoksydowej Epidian 5 produkcji Zakładów Chemicznych w Sarzynie, suspensyjnego polimetakrylanu metylu Metapleks S Zakładów Chemicznych w Oświęcimiu, krzemionki koloidalnej „Aerosil” - Degussa, mączek kwarcowych firmy „Quarzwerke” Frechen, 
mączki marmurowej firmy Omya-Köln, piasku szklarskiego o granulacji ${ }^{3}$ przechodzącej przez sito $0,20 \mathrm{~mm}$, metylohydroksyetylocelulozy produkcji Hoechst, Frankfurt - Tylose MHB 4000. Metakaolinit otrzymywano, wypalając kaolinit (import Czechy) w temperaturze $850-900^{\circ} \mathrm{C}$. Dyspergowane wapno hydratyzowane uzyskiwano w laboratorium, stosując dyspergator firmy Getzmann (Niemcy) ${ }^{4}$.

\section{Przygotowanie próbek zapraw}

Spoiwa mineralne mieszano z piaskiem i suchymi dodatkami modyfikującymi (metakaolinit, wapno i in.), a następnie z wodą zarobową.

Zaprawy umieszczano w normowych formach stalowych, izolowano je i po trzech dobach rozformowywano. Próbki wkładano do wody na 25 dób, a następnie suszono je w warunkach laboratoryjnych do stałej masy.

Ze względu na konieczność uzupełniania ubytków w piaskowcach na fasadzie ratusza, postanowiono przygotowywać zaprawy o konsystencji i plastyczności umożliwiającej prowadzenie prac „Z ręki”. Ilość wody koniecznej do uzyskania zapraw plastycznych obliczono, sumując współczynniki wodożądności kruszywa i cementów odczytane z tabel. Stosując dodatki modyfikujące, korygowano ilość wody, aby plastyczność zapraw była zbliżona. Współczynnik wodożądności piasku wynosił 0,15, cementu szarego 42,5, cementu białego 52,5-0,30, a metakaolinitu 0,7.

W przypadku zapraw o spoiwach polimerowych nadawano im właściwości hydrofilne za pomocą dodatków krzemionki koloidalnej. W tym celu mieszano żywice epoksydową z utwardzaczem i kruszywem, a następnie z zawiesiną krzemionki koloidalnej w wodzie. Zaprawy o spoiwie polimetakrylanu metylu otrzymywano nasteppująco: mieszano piasek z polimerem, do mieszaniny dodawano rozpuszczalniki, a następnie krzemionkę koloi-

3 Na podstawie analizy sitowej ustalono, że wielkość ziaren piaskowca Gotland mieści się w granicach 0,03 mm-0,19 mm, a piaskowca Obernkirchen 0,04 mm-0,16 mm. Biorąc pod uwage powyższe wyniki, postanowiono stosować do zapraw kruszywa o granulacji poniżej $0,20 \mathrm{~mm}$.

4 W. Domasłowski, J. W. Łukaszewicz, K. Lisek, Technologia farb do malowania zabytkowych fasad, grant KBN, 1998/2000, nr 7 T07F 01814. 
dalną w zawiesinie wodnej i wszystkie składniki mieszano. Próbki o wymiarach $4 \mathrm{~cm} \times 4 \mathrm{~cm} \times 16 \mathrm{~cm}$ sezonowano w warunkach laboratoryjnych przez 28 dób.

\section{Metodyka badań ${ }^{5}$}

Badania przeprowadzono z zastosowaniem następujących metod:

- ciężar objętościowy określano, dzieląc mase próbek przez ich objętość;

- skurcz określano, mierząc za pomocą suwmiarki długość wewnętrzną form stalowych, a następnie długość próbek zapraw po ich stwardnieniu i wysuszeniu do stałej masy;

- właściwości kapilarne zapraw badano na podstawie stopnia nasycenia woda po 6 i 24 godzinach kapilarnego nasycania (próbki zanurzone w wodzie na głębokość $1 \mathrm{~cm}$ ). Stopień nasycenia próbek obliczano w stosunku do ich nasiąkliwości ustalonej na drodze zanurzenia w wodzie(24 godziny). Tak samo określano zdolność kapilarnego podciagania cieczy organicznych. Odstąpiono od badania właściwości kapilarnych zapraw na drodze ustalania czasu wznoszenia się wody do konkretnej wysokości z uwagi na trudności precyzyjnego pomiaru. Woda wznosiła się nierównomiernie na poszczególnych płaszczyznach i na ogół bardzo wolno;

- nasiąkliwość wagową próbek badano po określeniu właściwości kapilarnych zapraw. Próbki umieszczano w pozycji poziomej, zalewano je woda ( $2 \mathrm{~cm}$ ponad górne powierzchnie) i po 24 godzinach ustalano przyrost masy;

- porowatość otwartą (nasiąkliwość objętościową) obliczano, mnożąc nasiąkliwość wagową przez ciężar objętościowy zapraw;

- wytrzymałość próbek na zginanie prowadzono na próbkach standardowych w aparacie RMU Testing Equipment;

- $\quad$ wytrzymałość próbek na ściskanie określano na połówkach próbek standardowych w prasie o nacisku 10-30 ton. Badano próbki suche oraz po 24-godzinnym nasycaniu wodą (odporność na działanie wody);

5 Badania laboratoryjne wykonał st. technik Krzysztof Lisek. 
- mrozoodporność zapraw badano, zamrażając nasycone wodą próbki (6 godzin) w temp. $-20^{\circ} \mathrm{C}$ i rozmrażając w wodzie o temperaturze pokojowej (18 godzin);

- odporność zapraw na działanie soli badano, nasycając je w nasyconym roztworze siarczanu sodowego przez 24 godziny, susząc je przez 20 godzin w temperaturze $105^{\circ} \mathrm{C}$ i ochładzając przez 4 godziny w temperaturze pokojowej (1 cyk1);

- odporność na ścieranie kamieni i zapraw badano w następujący sposób: na powierzchnie próbek wydmuchiwano w skonstruowanym urządzeniu piasek szklarski z odległości $50 \mathrm{~cm}$, pod ciśnieniem $1 \mathrm{~atm}$. Granulacja piasku wynosiła 0,125/0,25 mm. Badano stopień starcia powierzchni;

- przyczepność zapraw do piaskowców badano w aparacie RMU Testing Equipment, stosując przystawkę umożliwiającą badanie wytrzymałości na rozerwanie próbek zapraw z kamieniem.

Stosowane oznaczenia $\mathrm{w}$ tabelach: $\mathrm{C}_{\mathrm{ob}}-$ ciężar objętościowy $\left(\mathrm{g} / \mathrm{cm}^{3}\right)$, $\mathrm{N}_{\mathrm{H}_{2} \mathrm{O}}$ - nasiąkliwość wagowa wodą (\%), Po - porowatość otwarta (\%), $\mathrm{R}_{\mathrm{zg}}-$ wytrzymałość na zginanie $(\mathrm{MPa}), \mathrm{R}_{\mathrm{scc}}-$ wytrzymałość na ściskanie (MPa).

\section{Właściwości zapraw z piaskiem szklarskim o granulacji $0,2 \mathrm{~mm}$}

Zbadano właściwości mineralnych zapraw fabrycznych oraz otrzymanych w laboratorium. Stosując różną ilość piasku, określono właściwości zapraw z cementem białym, szarym i ich mieszaniną oraz wpływ ilości wody na właściwości zapraw cementowych i dodatków modyfikujących: metakaolinitu ${ }^{6}$, krzemionki koloidalnej ${ }^{7}$, mieszaniny metakaolinitu i krzemionki koloidalnej, zmielonych piaskowców, mączek kwarcowych i mączki marmurowej, metylohydroksyetylocelulozy. Poza wymienionymi zbadano właściwości za-

$6 \quad$ W. Domasłowski, Badania nad technologia hydraulicznych zapraw wapiennych, [w:] Problemy technologiczno-konserwatorskie malarstwa i rzeźby, Toruń 1992, s. 155; W. Domasłowski, M. Kęsy-Lewandowska, J. W. Łukaszewicz, Badania nad konserwacja murów ceglanych, Torun 1998, s. 107 i 132.

7 W. Domasłowski, M. Kęsy-Lewandowska, J. W. Łukaszewicz, op. cit., s. 101. 
praw cementowo-wapiennych, stosując wapno fabryczne (hydratyzowane) oraz wapno dyspergowane otrzymane w laboratorium.

\subsection{Badania fizykomechanicznych właściwości zapraw fabrycznych}

Badaniom poddano zaprawy cementowe dostarczone przez firmy Atlas (Polska) oraz Remmers i Keim (Niemcy). Firma Tubag zrezygnowała z opracowania zapraw o wyznaczonych parametrach.

\section{Omówienie wyników}

Jak wynika z tabeli 2, żadna z zapraw fabrycznych nie ma odpowiednich właściwości kapilarnych, aby mogła być zastosowana do uzupełniania ubytków w piaskowcach Gotland i Obernkirchen. Po 6 godzinach kapilarnego nasycania nie osiagnęły one 70\% nasycenia, jaki postulowano w stosunku do zapraw dla Obernkirchen, i ponad 95\% dla piaskowca Gotland ${ }^{8}$. Także po 24 godzinach zaprawy nie osiągnęły nasycenia 100\%.

Pozostałe właściwości zapraw są zbliżone do postulowanych.

\subsection{Badanie właściwości zapraw z białym cementem 52,5}

Biały cement stosowano, aby uzyskać zaprawy przeznaczone do uzupełniania ubytków w piaskowcu Obernkirchen. Ze względu na żółtawy kolor tego piaskowca szary cement nie nadaje się do tego celu. Badano wpływ ilości kruszywa na właściwości zapraw.

8 Także inne badania wykazały, że zaprawy firm Atlas i Remmers bardzo słabo podciągają wodę na drodze kapilarnej: D. Sobkowiak, Badania zapraw firmy Atlas przeznaczonych do stosowania $w$ pracach konserwatorskich, „Biuletyn Informacyjny Konserwatorów Dzieł Sztuki”, 1999, nr 2, s. 14; idem, Zaprawy Złoty Wiek firmy Atlas, „Biuletyn Informacyjny Konserwatorów Dzieł Sztuki”, 2000, nr 3, s. 26; M. Pikus, Ocena przydatności zapraw firmy Remmers do uzupetniania ubytków w piaskowcowych i ceglanych obiektach zabytkowych, cegłach, [w:] Ogólnopolska konferencja „Konserwacja murów ceglanych - badania i praktyka”, Toruń, 19-20.1 1.1999 r., s. 94; W. Domasłowski, Spoinowanie murów ceglanych i uzupełnianie ubytków w cegłach, [w:] Ogólnopolska konferencja „Konserwacja murów ceglanych - badania i praktyka", s. 70. 


\section{Omówienie wyników}

Jedynie próbki nr 2 i 3 (tab. 3) mają zbliżone właściwości kapilarne do zapraw postulowanych do uzupełniania ubytków w piaskowcu Gotland (nr 3) i Obernkirchen (nr 2). Pozostałe cechy można uznać także za zbliżone (nasiąkliwość, porowatość otwarta, wytrzymałość na ściskanie). Jedynie wytrzymałość na ściskanie zaprawy nr 3 jest nieco mniejsza (12,2\%) od wytrzymałości najniższej postulowanej do uzupełniania ubytków w piaskowcu Gotland. Na uwage zasługuje bardzo mały skurcz zapraw, niemożliwy do stwierdzenia za pomocą suwmiarki.

\subsection{Badanie właściwości zapraw z szarym cementem 42,5}

Szary cement stosowano, aby uzyskać zaprawy przeznaczone do uzupełniania ubytków w piaskowcu Gotland, który ma kolor szarozielony. Pozwoli to na ograniczenie wykorzystywania pigmentów w celu uzyskania zbliżonego zabarwienia zapraw do omawianego piaskowca.

Badano wpływ ilości kruszywa na właściwości zapraw.

\section{Omówienie wyników}

Zaprawy z cementem szarym (tab. 4) mają zbliżone nasiąkliwość, porowatość i wytrzymałość mechaniczną do zapraw z cementem białym, lecz gorsze właściwości kapilarne, co powoduje ich nieprzydatność jako spoiw zapraw cementowo-piaskowych przeznaczonych do uzupełniania ubytków w badanych piaskowcach.

Należy wspomnieć, że zgodnie z informacją producenta cement szary 42,5 jest przeznaczony na eksport i faktyczna wytrzymałość zapraw normowych z tym cementem wynosi 52,5 MPa. Dlatego też wytrzymałości mechaniczne zapraw z badanymi cementami są zbliżone.

\subsection{Badanie właściwości zapraw z mieszaniną (1:1) cementu białego 52,5 i szarego 42,5}

Badano właściwości zapraw z mieszaniną cementów, aby ewentualnie wykorzystać ją jako spoiwo zapraw do uzupełniania ubytków w piaskowcach 
Gotland i Obernkirchen. Zaprawy przeznaczone do piaskowca Gotland pigmentowano, do Obernkirchen - nie.

\section{Omówienie wyników}

Zaprawy z mieszaniną cementów (tab. 5) mają właściwości pośrednie pomiędzy zaprawami z cementem białym (tab. 3) i szarym (tab. 4).

Właściwości zapraw z pigmentami i bez ich dodatku są zbliżone.

\subsection{Badanie wpływu ilości wody zarobowej na właściwości zapraw cementowych}

W celu zwiększenia porowatości otwartej zapraw i poprawienia ich właściwości kapilarnych zwiększono ilość wody zarobowej o 10\% i 20\%.

Stosowano cement szary.

\section{Omówienie wyników}

Jak wynika z tabeli 6, przy zwiększaniu ilości wody zarobowej następuje pogorszenie właściwości kapilarnych zapraw. Przyczyną tego jest wzrost zagęszczenia zapraw, czego wyrazem są ich wyższe ciężary objętościowe.

\subsection{Badanie wpływu metakaolinitu na właściwości zapraw cementowych}

Metakaolinit jako dodatek aktywny wiąże wolny wodorotlenek wapnia, dzięki czemu nie następuje jego migracja w zaprawach cementowych. Stają się one stabilne i bardziej odporne na działanie czynników agresywnych. Stosując optymalną ilość metakaolinitu ${ }^{9}$ w stosunku do cementu szarego $(0,5: 1)$, zbadano wpływ ilości kruszywa na właściwości zapraw.

\section{Omówienie wyników}

Porównując właściwości zapraw o tych samych proporcjach spoiwo-kruszywo (tab. 7), niemodyfikowanych oraz zawierajacych metakaolinit, stwier- 
dzono, że dodatki metakaolinitu powodują wzrost nasiąkliwości zapraw oraz polepszenie właściwości kapilarnych, ponieważ ich użycie jest związane z koniecznością dodania większej ilości wody. Pomimo to żadna z próbek nie ma tak dobrych właściwości kapilarnych, aby można było ją zalecać jako zaprawę do uzupełniania ubytków w piaskowcach. Próbki nr 4 i 5 maja co prawda zbliżone właściwości kapilarne do piaskowca Obernkirchen, ale zbyt niską wytrzymałość mechaniczną.

\subsection{Badanie wpływu krzemionki koloidalnej na właściwości zapraw cementowych}

Krzemionka koloidalna, podobnie jak metakaolinit, należy do pucolanów i z tego powodu podjęto próby zastosowania jej do modyfikacji zapraw cementowych. Z uwagi na dużą wodochłonność i osłabianie właściwości mechanicznych zapraw (co wynika z poprzednich naszych badań ${ }^{10}$ ) zastosowano ją w ilości 0,025, 0,05 cz. na 1 cz. cementu.

Do badań użyto cementu białego.

\section{Omówienie wyników}

Porównując zaprawy modyfikowane (tab. 8) z niemodyfikowanymi (tab. 3) o tym samym stosunku cement:kruszywo, stwierdzono, że przy stosunku 1:3 dodatki krzemionki nie zmieniły w widocznym stopniu właściwości zapraw. W przypadku stosunku 1:4 nastapiło wyraźne polepszenie właściwości kapilarnych zapraw przy niewielkim spadku wytrzymałości na ściskanie.

Uznano, że zaprawa nr 3 wykazuje podobne właściwości kapilarne do piaskowca Obernkirchen i zgodną ze sformułowanym postulatem wytrzymałość na ściskanie.

10 Ibidem, s. 110. 


\subsection{Badanie wpływu metakaolinitu i krzemionki koloidalnej na właściwości zapraw cementowych}

Dążąc do poprawy kapilarnych właściwości zapraw, przy jednoczesnym utrzymaniu ich odpowiedniej wytrzymałości mechanicznej, zbadano wpływ mieszaniny metakaolinitu i krzemionki koloidalnej na właściwości zapraw. Stosowano cement biały, spodziewając się otrzymać zaprawy do uzupełniania ubytków w piaskowcu Obernkirchen.

\section{Omówienie wyników}

Jak wynika z tabeli 9, zaprawy z dodatkami metakaolinitu i krzemionki koloidalnej mają właściwości zbliżone do zapraw z metakaolinitem bądź krzemionką koloidalną. Żadna z badanych zapraw nie wykazuje właściwości odpowiednich do tego, aby mogła być użyta do uzupełniania ubytków w piaskowcach Obernkirchen i Gotland.

\subsection{Badanie wpływu dodatków metylohydroksyetylocelulozy na właściwości zapraw cementowych}

Dodatki metyloceluloz do zapraw cementowych i wapiennych są powszechnie stosowane jako czynnik higroskopijny zapobiegający odparowaniu wody, a więc ułatwiający procesy wiązania spoiw. Postanowiono sprawdzić, jaki wpływ bedzie miał dodatek metylohydroksyetylocelulozy (Tylose MHB 4000) na właściwości fizyczne i mechaniczne badanych zapraw cementowych. Przygotowano 2\% roztwór Tylose i stosowano go jako wodę zarobową. Badano zaprawę cementowo-piaskowa, cementowo-piaskową modyfikowaną krzemionką koloidalną oraz zaprawę cementowo-wapienno-piaskową (wapno dyspergowane). Próbki izolowano przed wyschnięciem przez 3 doby, a następnie suszono je w warunkach laboratoryjnych przez 25 dób.

\section{Omówienie wyników}

Jak wynika z tabeli 10, dodatki metylohydroksyetylocelulozy uniemożliwiają kapilarne wznoszenie się wody, czego przyczyną jest prawdopodobnie jej pecznienie w kapilarach zaprawy. Poza tym zaprawy z omawianym modyfi- 
katorem mają niższą wytrzymałość na ściskanie od niemodyfikowanych (porównanie: tab. 10, pr. 1 - tab. 4, pr. 2; tab. 10, pr. 2 - tab. 8, pr. 2; tab. 10, pr. 3 - tab. 12, pr. 1).

\subsection{Badanie wpływu dodatków wapna hydratyzowanego na właściwości zapraw cementowych}

Dodatki wapna do cementu polepszają właściwości kapilarne zapraw, ponieważ wapno ma prawie dwukrotnie większą wodożądność, niemniej jednak obniżają ich wytrzymałość mechaniczną. Biorąc to pod uwage, zastosowano proporcje cement:wapno $=1,5: 0,5$ i 1:1, ilości piasku natomiast $\mathrm{w}$ stosunku do mieszanego spoiwa w granicach od 1:2 do 1:3,5.

Badano zaprawy z cementem szarym.

\section{Omówienie wyników}

Porównując zaprawy z dodatkami wapna (tab. 11) i bez nich (tab. 4) o stosunku spoiwo:kruszywo $=1: 3$, stwierdzono, że dodatki wapna $\mathrm{w}$ małym stopniu polepszają właściwości kapilarne zapraw o stosunku cement:wapno $=1,5: 0,5$. Duże polepszenie właściwości kapilarnych obserwujemy w zaprawach o stosunku cement:wapno $=1: 1$. Towarzyszy temu jednak obniżenie wytrzymałości zapraw na ściskanie: przy zaprawach cement:wapno: :piasek $=1: 1: 4$ o około 44\%, a przy zaprawach 1:1:6 o prawie 70\%. Podobne prawidłowości zaobserwowano, badając zaprawy cementowo-wapienne z białym cementem marki 45 i 35 oraz piaskiem kwarcowym o granulacji 0,25/05 $\mathrm{mm}^{11}$.

Biorąc pod uwage postulowane parametry zapraw przeznaczonych do uzupełniania ubytków w badanych piaskowcach, można stwierdzić, że zaprawa nr 3 charakteryzuje się właściwościami zbliżonymi do zapraw przeznaczonych do uzupełniania ubytków w piaskowcu Gotland.

11 Ibidem, s. 118. 


\subsection{Badanie wpływu dodatków dyspergowanego wapna hydratyzowanego na właściwości zapraw cementowych}

Ze względu na to, że zaprawy z wapnem dyspergowanym odznaczaja się znacznie lepszymi właściwościami niż z wapnem hydratyzowanym, zastosowano je do badań w celu polepszenia właściwości mechanicznych zapraw cementowo-wapiennych. Stosowano wapno dyspergowane ${ }^{12}$, uzyskane z wapna hydratyzowanego, o stężeniu 50\%.

Zaprawy przygotowano na bazie cementu szarego.

\section{Omówienie wyników}

Porównując właściwości zapraw 1:3 oraz 1:3,5 z wapnem hydratyzowanym (tab. 11) i dyspergowanym wapnem hydratyzowanym (tab. 12), stwierdzono niewielki wzrost wytrzymałości zapraw z wapnem dyspergowanym $(6 \div 22 \%)$ i równocześnie znaczne pogorszenie właściwości kapilarnych, co ogranicza użycie tego wapna jako składnika zapraw do uzupełniania ubytków w piaskowcach Gotland i Obernkirchen.

\subsection{Podsumowanie wyników badań}

Celem podjętych badań było opracowanie technologii zapraw cementowych z piaskiem o granulacji $0,2 \mathrm{~mm}$ do uzupełniania ubytków w piaskowcach Gotland i Obernkirchen. Ustalono, że stopień nasycenia próbek zapraw $(4 \mathrm{~cm} \times 4 \mathrm{~cm} \times 8 \mathrm{~cm})$ dla piaskowca Gotland po 6 godzinach kapilarnego nasycania powinien wynosić ponad $95 \%$, a więc próbki powinny być w tym okresie praktycznie nasycone woda. Stopień nasycenia zapraw dla piaskowca Obernkirchen powinien natomiast wynosić po 6 godzinach nasycania 70\%, a po 24 godzinach - 100\%. Takie średnie właściwości kapilarne maja omawiane piaskowce. Wytrzymałość na ściskanie zapraw powinna mieścić się w granicach: zaprawy dla piaskowca Gotland $15 \div 20 \mathrm{MPa}$, a dla Obernkirchen $20 \div 30 \mathrm{MPa}$. W tym przypadku zakładano, że wytrzymałości po-

12 W. Domasłowski, J. W. Łukaszewicz, K. Lisek, op. cit. 
winny być niższe z uwagi na to, że zaprawy będą stosowane do uzupełniania ubytków w piaskowcach o obniżonej wytrzymałości.

Warunki te są bardzo trudne do spełnienia, ponieważ dwa wymienione parametry wzajemnie się wykluczają. Wzrostowi wytrzymałości towarzyszy spadek właściwości kapilarnych i odwrotnie przy obniżaniu wytrzymałości.

Otrzymanie zapraw o dobrych właściwościach kapilarnych, przy jednocześnie odpowiedniej wytrzymałości mechanicznej, umożliwiało użycie jako spoiwa cementów wysokiej marki. Można było do nich dodawać dużych ilości kruszywa. Wraz z jego wzrostem polepszają się właściwości kapilarne zapraw, lecz ulegają obniżeniu właściwości mechaniczne. Zmieniając więc ilość kruszywa do spoiwa cementowego, ustalono zaprawy o optymalnych właściwościach. Starano się je polepszyć, stosując dodatki modyfikujące: metakaolinit, krzemionkę koloidalną, metylocelulozę oraz wapno hydratyzowane i dyspergowane wapno hydratyzowane.

Ponadto zwrócono się do znanych producentów zapraw budowlanych przeznaczonych do konserwacji zabytków z propozycją opracowania zapraw odpowiadających wyżej sformułowanym postulatom.

W wyniku przeprowadzonych badań stwierdzono:

1. Zaprawy fabryczne nie mają odpowiednich właściwości kapilarnych, aby można je było stosować do uzupełniania ubytków w piaskowcach Gotland i Obernkirchen.

2. Dodatki metakaolinitu polepszają właściwości kapilarne zapraw cementowych, jednak badane zaprawy nie odpowiadają całkowicie stawianym wymaganiom.

3. Dodatki krzemionki koloidalnej polepszają właściwości kapilarne zapraw cementowych (stosunek cement:piasek $=1: 4$ ), przy niewielkim spadku ich wytrzymałości na ściskanie.

4. Metylohydroksyetyloceluloza pogarsza właściwości kapilarne zapraw.

5. Zaprawy o spoiwie mieszanym cement-wapno hydratyzowane wykazują lepsze właściwości kapilarne od zapraw czysto cementowych. Optymalny stosunek cement:wapno wynosi 1:1. Obniżeniu ulega wytrzymałość zapraw cementowych na ściskanie.

6. Dodatki dyspergowanego wapna hydratyzowanego nie polepszają właściwości kapilarnych zapraw. 
Biorąc pod uwagę ustalone kryteria (właściwości kapilarne i mechaniczne), w tabeli 13 zestawiono zaprawy o optymalnych właściwościach. Właściwości kapilarne tych zapraw mieszczą się w granicach ustalonych dla zapraw do uzupełniania ubytków w piaskowcach Gotland i Obernkirchen.

Do uzupełniania ubytków w piaskowcu Gotland najbardziej odpowiednie są zaprawy nr 4 i 7, które mają najlepsze właściwości kapilarne (stopień nasycenia wodą na drodze kapilarnej po 6 godzinach $83 \div 97 \%$ ) przy wytrzymałości na ściskanie wynoszącej około $15 \mathrm{MPa}$. Mankamentem ich jest większa od postulowanej nasiąkliwość wodą (o około 50\%).

Do uzupełniania ubytków w piaskowcu Obernkirchen najlepsze są zaprawy nr 3 i 6, których stopień nasycenia wodą po 6 godzinach kapilarnego podciągania wynosi $62 \div 71 \%$, po 24 godzinach $100 \%$, a wytrzymałość na ściskanie około $20 \mathrm{MPa}$.

\section{Właściwości zapraw cementowych z piaskiem szklarskim 0,20 mm imitujących piaskowce Gotland i Obernkirchen}

Wytypowane zaprawy na podstawie badań opisanych w p. 5, po ich podbarwieniu upodabniajacym je do piaskowca Gotland i Obernkirchen ${ }^{13}$, poddano dalszym badaniom.

Zaprawy do uzupełniania ubytków w piaskowcu Gotland otrzymano, stosując szary cement marki 42,5 (lub w mieszaninie z białym 52,5), piasek szklarski przechodzący przez sito $0,20 \mathrm{~mm}$ oraz pigmenty.

Zaprawy do uzupełniania ubytków w piaskowcu Obernkirchen otrzymano, stosując biały cement marki 52,5, piasek szklarski przechodzący przez sito $0,20 \mathrm{~mm}$ oraz pigmenty.

Określono następujące właściwości zapraw:

- wytrzymałość na ściskanie i nasiąkliwość wodą,

- kapilarne podciagganie cieczy organicznych,

- odporność na sole,

13 Zaprawy podbarwiała prof. dr hab. J. Łukaszewicz. 
- odporność na zamrażanie,

- twardość powierzchniowa (odporność na ścieranie),

- przyczepność do piaskowców.

Oznaczenia i skład zapraw:

\section{Gotland 1}

cement szary i biały $(1: 1)+$ piasek + woda $=1: 5: 1,20$

pigmenty:

czerń $\quad-0,097 \%$ (w stosunku do zaprawy)

ugier $\quad-0,074 \%$

\section{Gotland 2}

cement szary + wapno hydratyzowane + piasek + woda $=1: 1: 4: 1,32$

pigmenty:

czerń $\quad-0,380 \%$

sjena naturalna $\quad-0,140 \%$

umbra naturalna $\quad-0,200 \%$

\section{Obernkirchen 1}

cement biały + piasek + woda $=1: 4: 0,90$

pigmenty:

czerń $\quad-0,100 \%$

sjena naturalna $\quad-0,125 \%$

sjena palona $\quad-0,045 \%$

ugier $\quad-0,060 \%$

czerwień żelazowa $\quad-0,041 \%$

\section{Obernkirchen 2}

cement biały + krzemionka koloidalna + piasek + woda $=1: 4: 0,025: 1,00$ pigmenty - jak wyżej

\subsection{Wytrzymałość zapraw na ściskanie}

Celem badań było sprawdzenie, czy dodatki pigmentów nie spowodowały zmian wytrzymałości zapraw na ściskanie. Średnie wyniki z pomiarów podano w tabeli 14. 


\section{Omówienie wyników}

Porównując wytrzymałości zapraw niebarwionych i barwionych (tab. 14), można stwierdzić, że są one do siebie zbliżone. Niewielkie dodatki pigmentów nie mają wpływu na właściwości mechaniczne zapraw.

\subsection{Zdolność kapilarnego podciągania benzyny lakowej przez zaprawy oraz ich nasiąkliwość}

Celem doświadczenia było zbadanie możliwości nasycania zapraw preparatami na bazie rozpuszczalników organicznych (np. Steinfestiger OH) i określenie ich nasiąkliwości.

\section{Omówienie wyników}

Porównując nasiąkliwość wodą zapraw o tym samym składzie (tab. 13) i nasiąkliwość benzyną lakową (tab. 15), można stwierdzić (po podzieleniu masy benzyny przez jej gęstość), że są one zbliżone w przypadku próbek nr 3, 4 i 7 (tab. 13) i próbek nr 1, 2 i 3 (tab. 15). Jedynie zaprawa nr 4 z tabeli 15 ma o około 40\% większą nasiąkliwość benzyną od nasiąkliwości wodą zaprawy nr 6 z tabeli 13.

Zdolność kapilarnego podciągania benzyny lakowej jest zbliżona (nieco gorsza) niż wody.

\subsection{Odporność zapraw na działanie soli (test solny)}

Celem badań było porównanie odporności zapraw i piaskowców Obernkirchen i Gotland na działanie soli. Badano zgodnie z metodyką opisaną w p. 4.

Do badań użyto po 3 próbki zapraw i porównywano je z 22 próbkami poszczególnych piaskowców.

Wyniki przedstawiają tabela 16 i ilustracja 1.

\section{Omówienie wyników}

Z tabeli 16 wynika, że odporność zapraw na test solny jest zbliżona do odporności piaskowców. Zaprawy przeznaczone do uzupełniania ubytków 
w piaskowcu Gotland mają nieco większą odporność, a w piaskowcu Obernkirchen nieco mniejszą.

\subsection{Odporność zapraw na zamrażanie}

Badania przeprowadzono zgodnie z punktem 4. Po wykonaniu 20 cykli stwierdzono, że żadna z zapraw nie uległa zniszczeniu. Poddano je zgniataniu w prasie hydraulicznej i określono wytrzymałość. Wyniki zestawiono w tabeli 17 .

\section{Omówienie wyników}

Na podstawie uzyskanych wyników (tab. 17) możemy stwierdzić, że wytrzymałość badanych zapraw nie uległa zmianie po 20 cyklach zamrażania. Są one mrozoodporne.

\subsection{Odporność na ścieranie}

Celem badań było porównanie odporności na ścieranie powierzchni zapraw z odpornością piaskowców Gotland i Obernkirchen. Na próbki skierowywano piasek pod ciśnieniem 1 atm w 4 punktach, w przypadku zapraw - począwszy od górnej partii do dolnej, a piaskowców - począwszy od górnego, lewego rogu, a nasteppnie zgodnie z kierunkiem ruchu wskazówek zegara. Stosowano kolejno: 50 g, 100 g, 200 g, 300 g piasku, co obrazują rysunki 1 i 2.

Badaniom poddano po dwa rodzaje piaskowców różniących się strukturą, a więc także właściwościami kapilarnymi i mechanicznymi. Były to piaskowce wolno i szybko podciągające wodę.

$\mathrm{Na}$ badane próbki nakładano blachę z wyciętymi w niej okrągłymi otworami, dzięki czemu wytrawiane przez piasek powierzchnie przyjmowały kształt koła. Porównywano głębokość powstałych wżerów przy określonej ilości piasku.

Wyniki przedstawiają tabela 18 i ilustracja 2.

\section{Omówienie wyników}

Jak wynika z tabeli 18, mniejszą odpornością na ścieranie charakteryzują się próbki piaskowców o dobrych właściwościach kapilarnych oraz zaprawa 
Gotland 1 (cement:piasek = 1:5) i Obernkirchen 2 (cement:krzemionka koloidalna:piasek $=1: 4: 0,025)$. Pozostałe piaskowce i zaprawy mają większą odporność. Ogólnie można stwierdzić, że zaprawy mają odporność na ścieranie zbliżoną do badanych piaskowców.

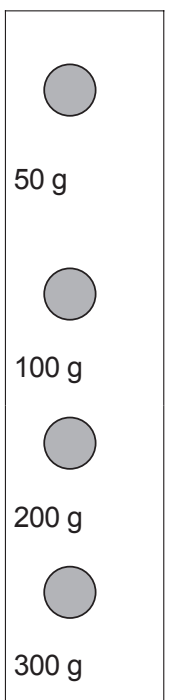

Rys. 1. Punkty nanoszenia piasku na zaprawy

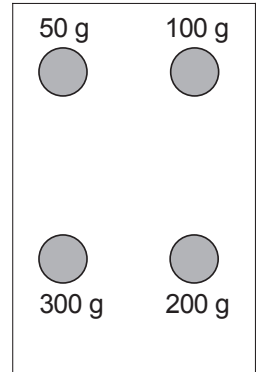

Rys. 2. Punkty nanoszenia piasku na piaskowce

\subsection{Przyczepność zapraw do piaskowców Obernkirchen i Gotland}

W celu określenia przyczepności zapraw do piaskowców Gotland i Obernkirchen $\mathrm{w}$ formach stalowych $(4 \mathrm{~cm} \times 4 \mathrm{~cm} \times 16 \mathrm{~cm})$ umieszczano kształtki piaskowców o wymiarach $4 \mathrm{~cm} \times 4 \mathrm{~cm} \times 4 \mathrm{~cm}$, a następnie, po zwilżeniu ich powierzchni woda, wprowadzano do formy zaprawe o tych samych wymiarach i kształcie i ubijano ją. Próbki pozostawiano przez 3 doby w szczelnie przykrytych formach i po rozformowaniu wkładano je do wody na 25 dób. Po wysuszeniu w warunkach normalnych badano przyczepność zapraw do wymienionych podłoży zgodnie z opisem w p. 4.

\section{Omówienie wyników}

Próbki zapraw nr 2, 3, 4 (tab. 19) oderwały się od podłoża kamiennego, natomiast próbka nr 1 uległa rozwarstwieniu, nie tracąc przyczepności do podłoża. Ostatni przypadek świadczy o tym, że przyczepność zaprawy jest większa 
od jej wytrzymałości na rozrywanie. Z tabeli wynika, że zaprawy mają znacznie lepszą przyczepność do piaskowca Gotland niż Obernkirchen, czego wytłumaczeniem jest niekorzystna, bardziej drobnoporowata struktura piaskowca Obernkirchen. Przyczepność zapraw nie odbiega od przyczepności standardowych zapraw mineralnych. Można uznać, że jest ona wystarczająca dla piaskowca Gotland, lecz zbyt mała dla piaskowca Obernkirchen.

\subsection{Podsumowanie wyników badań}

Badania zapraw imitujących piaskowce Gotland i Obernkirchen pozwoliły na stwierdzenie, że dodatki pigmentów nie wpłynęły na ich właściwości fizyczne i mechaniczne. Zaprawy te miały poza tym zbliżoną zdolność kapilarnego podciagania benzyny lakowej do wody oraz zbliżone nasiąkliwości objętościowe benzyną i wodą. Charakteryzowały się także zbliżoną do piaskowców odpornością na działanie soli (test solny) oraz na ścieranie (twardość powierzchniowa). Odznaczały się całkowitą odpornością na zamrażanie (20 cykli). Przyczepność zapraw do piaskowca Gotland uznano za wystarczająca, a do Obernkirchen za zbyt małą.

\section{Właściwości zapraw z dodatkami kruszyw drobnoziarnistych oraz mączki kwarcowej i marmurowej}

Dążąc do uzyskania zapraw o zbliżonych właściwościach do badanych piaskowców, podjęto dodatkowe badania nad technologią zapraw mineralnych ze spoiwem cementowym, wykorzystując następujące dodatki:

- drobnoziarniste kruszywo z piaskowca Gotland i Obernkirchen, - mączkę kwarcową i marmurową.

Ze względu na to, że stosowanie kruszyw i wypełniaczy o małej ziarnistości pociąga za sobą konieczność zwiększania ilości wody zarobowej, zakładano, że nastapi polepszenie kapilarnych właściwości zapraw.

Zaprawy otrzymywano i badano zgodnie $\mathrm{z}$ opisem zamieszczonym w p. 3 . W badaniach stosowano biały cement portlandzki marki 52,5 oraz piasek szklarski o granulacji przechodzącej przez sito 0,2 $\mathrm{mm}$. 


\subsection{Wpływ drobnoziarnistego kruszywa z piaskowców Gotland i Obernkirchen na właściwości zapraw}

Próbki badanych piaskowców zmielono i przesiano przez sito o wymiarach oczek 0,125 mm.

\section{Omówienie wyników}

Na podstawie uzyskanych rezultatów (tab. 20) stwierdzono, że drobnoziarniste kruszywo nie poprawiło właściwości kapilarnych zapraw. Nie spełniają one sformułowanych postulatów dotyczących cech zapraw przeznaczonych do uzupełniania ubytków w piaskowcach Gotland i Obernkirchen. Wzrosła natomiast znacznie nasiąkliwość zapraw (o około 100\%) w stosunku do zapraw z piaskiem o granulacji 0,20 mm (tab. 3). Przyczyną słabych właściwości kapilarnych są prawdopodobnie tworzące się w zaprawie pory o mniejszych średnicach.

\subsection{Wpływ mączki kwarcowej i marmurowej na właściwości zapraw}

Stosowano mączki kwarcowe o wielkości ziarna $4 \div 13 \mu \mathrm{m}$ i $40 \mu \mathrm{m}$ oraz mączkę marmurową o średniej wielkości ziarna $40 \mu \mathrm{m}$.

\subsubsection{Wpływ rodzaju mączki na właściwości zapraw}

\section{Omówienie wyników}

Jedynie zaprawy z dodatkiem mączki kwarcowej $4 \div 13 \mu \mathrm{m}$ (tab. 21) maja nieco lepsze właściwości kapilarne od zapraw cementowo-piaskowych o tym samym stosunku spoiwo:kruszywo. Pozostałe zaprawy z dodatkami mączki kwarcowej i marmurowej $40 \mu \mathrm{m}$ wykazują nieco gorsze właściwości kapilarne (nr 2) lub zbliżone (nr 3) do zaprawy cementowo-piaskowej (nr 4). $\mathrm{Na}$ uwagę natomiast zasługują większe o $80 \div 100 \%$ nasiąkliwości zapraw z dodatkami mączek oraz bardzo duże ich wytrzymałości na ściskanie, przewyższające zaprawy cementowe o tym samym składzie cement:kruszywo o około $64 \div 152 \%$. Na wyróżnienie zasługują zaprawy z mączką kwarcową o największej wytrzymałości (nr 2 - $69 \mathrm{MPa}$ ). 


\subsubsection{Właściwości zapraw z dodatkami mączek otrzymanymi przy zmiennej ilości piasku}

\section{Omówienie wyników}

Biorąc pod uwagę wyniki badań (tab. 22), można stwierdzić, że najlepsze właściwości kapilarne i mechaniczne mają zaprawy z dodatkiem mączki kwarcowej $40 \mu \mathrm{m}$, niemniej jednak żadna z nich nie spełnia wymagań stawianych zaprawom do uzupełniania ubytków w piaskowcach Gotland i Obernkirchen. Na uwage zasługuje bardzo duża wytrzymałość tych zapraw na ściskanie, szczególnie z mączką kwarcową $40 \mu \mathrm{m}$, przekraczająca wytrzymałość zapraw cementowych o tym samym stosunku spoiwo:piasek średnio o $135 \%$.

\subsubsection{Wpływ ilości mączki kwarcowej na właściwości zapraw}

Zachowując stały stosunek cement:wypełniacz + kruszywo (1:8), zmieniano ilość mączki $(40 \mu \mathrm{m})$ w stosunku do cementu, aby sprawdzić wpływ tych składników na właściwości kapilarne i wytrzymałość zapraw.

Omówienie wyników

Dobre właściwości kapilarne (tab. 23) mają zaprawy 1 $\div 3$, w których stosunek cement:mączka nie przekracza 1:1,5. Wraz ze zwiększaniem ilości mączki kwarcowej właściwości kapilarne zapraw pogarszają się, przy czym bardzo złymi odznaczają się zaprawy 5 i 6 . Wytrzymałość na ściskanie zapraw rośnie wraz ze zwiększaniem ilości mączki, aczkolwiek od zależności tej odbiegają próbki nr 4 i 5.

\subsubsection{Odporność zapraw z mączką kwarcową na działanie siarczanu sodowego}

Badania prowadzono zgodnie z opisem podanym w p. 4, stosując nasycony roztwór siarczanu sodowego. Badano zaprawy nr $1-3$ z tabeli 23. Wyniki zamieszczono w tabeli 24 oraz na ilustracjach 3-6.

Omówienie wyników

Podobnie jak w poprzednich badaniach (tab. 16) największym zniszczeniom (tab. 24) uległy próbki piaskowca Gotland, a najmniejszym Obern- 
kirchen. Spośród zapraw najmniej odporna była zaprawa z najmniejszą ilością mączki kwarcowej (0,5 cz.), najbardziej odporna natomiast z największą ( 1,5 cz.). Zniszczenia najodporniejszej zaprawy były zbliżone do piaskowca Obernkirchen.

\subsubsection{Odporność zapraw na zamrażanie}

Badania prowadzono zgodnie z opisem w p. 4.

Po 20 cyklach zamrażania i rozmrażania nie zaobserwowano objawów zniszczeń zapraw (il. 7). Próbki miały wytrzymałość na ściskanie zbliżoną do tej przed testem na zamrażanie.

\subsubsection{Przyczepność zapraw cementowych modyfikowanych mączką kwarcową do piaskowców}

\section{Omówienie wyników}

Przyczepność zapraw, szczególnie nr 1 i 2, jest bardzo duża (tab. 25). Wzrasta ona wraz ze zwiększaniem ilości mączki kwarcowej. Poszczególne zaprawy odrywały się od piaskowców, uszkadzając w małym lub znacznym stopniu ich powierzchnie (do około 20\%), co prezentuje il. 8.

\subsubsection{Odporność zapraw na ścieranie}

Badania przeprowadzono zgodnie z opisem zawartym w p. 4.

Omówienie wyników

Na podstawie il. 9 przedstawiającej wyniki stwierdzono, że odporność zapraw na ścieranie rośnie wraz z zawartością mączki kwarcowej. Najmniej odporna jest zaprawa nr 1 (tab. 23), w następnej kolejności zaprawa nr 2, a nr 3 nie wykazała żadnych zmian i przewyższa odpornością na ścieranie badane piaskowce.

\subsection{Podsumowanie wyników badań}

$\mathrm{Na}$ podstawie przeprowadzonych badań stwierdzono, że drobnoziarniste kruszywo (poniżej 0,125 mm) nie poprawiło właściwości kapilarnych za- 
praw cementowych. Wzrosła natomiast znacznie ich nasiąkliwość (o około 100\%) w stosunku do zapraw z piaskiem o granulacji 0,20 mm.

Interesujący wpływ na właściwości zapraw cementowych mają natomiast dodatki mączek kwarcowych i marmurowych. Zwiększają one wytrzymałość zapraw, dzięki czemu można dodawać do nich większe ilości piasku. Szczególnie dobre właściwości kapilarne wykazuja zaprawy z dodatkami mączki kwarcowej o granulacji $40 \mu \mathrm{m}$. Spośród nich na uwagę zasługują zaprawy nr 2 i 3 (tab. 23). Mogą być one stosowane do uzupełniania ubytków w piaskowcach Gotland i Obernkirchen. Ich wytrzymałość na ściskanie wynosi od $13 \mathrm{MPa}$ do $18 \mathrm{MPa}$, a czas kapilarnego podciągania wody do wysokości 5 cm około 136 minut i 260 minut. Odporność zapraw z mączką kwarcową na zamrażanie jest całkowita, a na działanie soli większa od piaskowca Gotland i zbliżona do piaskowca Obernkirchen. Zaprawy te mają także bardzo dobra przyczepność do piaskowców i są odporne na ścieranie.

\section{Właściwości hydrofilnych zapraw o spoiwach polimerowych}

Celem badań było opracowanie technologii zapraw o spoiwach polimerowych przeznaczonych do uzupełniania ubytków w piaskowcach Gotland i Obernkirchen. Do jego realizacji zastosowano żywice epoksydową produkcji polskiej Epidian 5 oraz polimetakrylan metylu spolimeryzowany w suspensji (proszek).

Badania mają na celu opracowanie technologii zapraw o cechach sformułowanych w p. 1, tab. 1. Oprócz omówionych właściwości fizycznych i mechanicznych powinny być one hydrofilne. Udało się otrzymać takie zaprawy z żywicą epoksydowa ${ }^{14}$. Ich właściwości hydrofilne uzyskano, dodając do żywic substancje dobrze zwilżalne. Najbardziej przydatna do tego celu okazała się krzemionka koloidalna. Jej niewielkie ilości zmieniają hydrofobowe właściwości zapraw epoksydowych w zaprawy całkowicie hydrofilne,

14 W. Domasłowski, Spoinowanie murów ceglanych..., s. 80. 
doskonale podciaggające wodę na drodze kapilarnej. Stosując do utwardzania żywicy addukty, otrzymano zaprawy o dużej odporności na działanie UV ${ }^{15}$.

Przeprowadzając badania z zastosowaniem polimetakrylanu metylu, opracowano technologię zapraw wiążących w masach o dowolnej objętości i grubości. Uzyskano to dzięki wykorzystaniu roztworów omawianej żywicy o bardzo wysokim stężeniu, a mianowicie 40\%. Wysoka lepkość roztworów zapobiega migracji żywicy w czasie schnięcia zapraw, a zarazem nadaje im odpowiednia plastyczność ${ }^{16}$. Zaprawy te mają właściwości hydrofobowe. W celu nadania im właściwości hydrofilnych zostały podjęte niżej opisane badania.

Zaprawy ze spoiwami polimerowymi są szczególnie przydatne w przypadku uzupełniania niewielkich ubytków w kamieniach naturalnych, gdyż mogą być nakładane w bardzo cienkich warstewkach.

\subsection{Hydrofilne zaprawy o spoiwie epoksydowym}

Do badań zastosowano żywice polskiej produkcji Epidian 5. Utwardzano ją adduktem Epidian5/trójetylenoczteroamina przygotowanym laboratoryjnie. Addukt otrzymywano przez zmieszanie 100 g żywicy z $87 \mathrm{ml} \mathrm{TECZA}$ w $100 \mathrm{ml}$ mieszaniny toluenu i butanolu $(1: 2,5)$. Po zajściu reakcji uzupełniano roztwór ww. rozpuszczalnikiem do objętości $300 \mathrm{ml}$. W celu utwardzenia do 100 g żywicy (o liczbie epoksydowej 0,52-0,55) dodawano $50 \mathrm{ml}$ roztworu adduktu.

Aby nadać zaprawom właściwości hydrofilne, mieszano żywice z kruszywem, a nastepnie z zawiesiną krzemionki koloidalnej w wodzie. Jako kruszywo stosowano piasek szklarski o granulacji <0,20 mm oraz jego mieszaninę z piaskiem o granulacji 0,5/1,0 mm.

15 Technologia zapraw epoksydowych $w$ niskich temperaturach $i w$ atmosferze o wysokiej wilgotności, „Acta Universitatis Nicolai Copernici, Zabytkoznawstwo i Konserwatorstwo”, 1990 , t. 15, s. 58.

16 W. Domasłowski, A. Strzelczyk, Thermoplastic Polymers as Binders of Artificial Stone, [w: Conservation of Architectural Surfaces: Stones and Wall Covering, Il Cadro, Venezia 1993, s. 155. 
Badano właściwości kapilarne zapraw, stopień nasycenia wodą po 6 godzinach nasycania kapilarnego, nasiąkliwość wodą po 24 godzinach zanurzenia $\left(\mathrm{N}_{\mathrm{H}_{2} \mathrm{O}}\right)$, wytrzymałość na ściskanie (Rc), odporność na działanie siarczanu sodowego (test solny), na zamrażanie oraz przyczepność do piaskowców.

\subsubsection{Właściwości zapraw niezwiązanych}

Ze względu na stosowanie roztworu adduktu spoiwo ma stosunkowo mała lepkość i można łatwo zmieszać je z kruszywem. Dodając do spoiwa 10-30 części kruszywa, uzyskuje się zaprawy o dobrej, lecz malejącej plastyczności, które nie spływają przy nanoszeniu ich na pionowe płaszczyzny podłoża kamiennego. Czas pracy z omawianymi zaprawami w temperaturze $20^{\circ} \mathrm{C}$ wynosi minimum 60 minut, niemniej jednak ze względu na obecność rozpuszczalników lotnych należy przygotowywać zaprawy w porcjach, które powinny być zużyte w czasie 30 minut.

\subsubsection{Badania wstępne}

8.1.2.1. Określenie wpływu ilości krzemionki koloidalnej i kruszywa na właściwości zapraw epoksydowych

\section{Omówienie wyników}

Jak wynika z tabeli 26, stosując kruszywo w ilości od 10 do 30 części wagowych na 1 część żywicy, uzyskano zaprawy bardzo różniące się nasiąkliwością wodą i wytrzymałością na ściskanie. Jedynie zaprawy o stosunku żywica:piasek = 1:10 mają zbliżoną nasiąkliwość do badanych piaskowców. Nasiąkliwość pozostałych jest znacznie wyższa. Wytrzymałość na ściskanie zapraw o stosunku 1:10 przekracza znacznie wytrzymałość postulowaną dla zapraw do uzupełniania piaskowców. Zbliżone właściwości mechaniczne mają natomiast zaprawy 1:20 (do piaskowca Obernkirchen) i 1:30 (do piaskowca Gotland).

Badania wykazały, że dodatki krzemionki koloidalnej nadały zaprawom doskonałe właściwości hydrofilne. Można przypuszczać, że dzięki nim, jak też szerokoporowatej strukturze zapraw, podciagają one bardzo szybko wodę na drodze kapilarnej. Wpływ ilości krzemionki koloidalnej (10-30\%) okazał się mało istotny dla właściwości kapilarnych zapraw, natomiast mniejsze dodatki $(2,5 \%, 5 \%)$ są niewystarczające, aby nadać zaprawom charakter 
hydrofilny. Na tej podstawie stwierdzono, że właściwości badanych zapraw są bardzo interesujące i istnieje celowość kontynuowania badań.

8.1.2.2. Określenie wpływu mieszaniny kruszyw o różnej granulacji na właściwości zapraw epoksydowych

W celu zmniejszenia zdolności kapilarnego podciagania wody przez hydrofilowe zaprawy epoksydowe zastosowano mieszaninę kruszyw o mniejszej porowatości, a więc o większym zagęszczeniu ziaren. Użyto mieszaniny piasku o następującej granulacji: 0/5/1,0 mm (70\%) i > 0,2 mm (30\%).

\section{Omówienie wyników}

Porównując wyniki zawarte w tabelach 26 i 27, stwierdzono, że użycie mieszaniny piasku nie ograniczyło szybkości kapilarnego wznoszenia się wody w zaprawach, a nawet obserwujemy jej szybsze wznoszenie się. Zmalała natomiast nasiąkliwość wodą i wzrosła wytrzymałość na ściskanie. Ponieważ zaprawy z gruboziarnistym kruszywem różnią się strukturą od badanych piaskowców, postanowiono prowadzić dalsze doświadczenia z jednofrakcyjnym kruszywem drobnoziarnistym.

\subsubsection{Badania właściwości fizycznych i mechanicznych hydrofilnych zapraw epoksydowych}

Stosując żywice epoksydową Epidian 5 (EP), addukt tej żywicy z trójetylenoczteroaminą (AD) oraz piasek szklarski frakcji $<0,2 \mathrm{~mm}$, badano zaprawy o następującym składzie:

1. 1 cz. EP/AD:20 cz. piasku:0,1 cz. 10\% zawiesiny krzemionki koloidalnej;

2. 1 cz. EP/AD:30 cz. piasku:0,1 cz. 10\% zawiesiny krzemionki koloidalnej.

Określono następujące właściwości zapraw: skurcz, ciężar objętościowy, właściwości kapilarne, nasiąkliwość wodą po 6 i 24 godzinach, wytrzymałość na zginanie, wytrzymałość na ściskanie na sucho i mokro, odporność na zamrażanie, ścieranie i na sole oraz przyczepność do kamieni naturalnych.

\subsubsection{Badanie właściwości wybranych zapraw}

Badania przeprowadzono zgodnie z opisem zamieszczonym w p. 4. Wyniki badań zamieszczono w tabeli 28. 


\section{Omówienie wyników}

Zaprawy epoksydowe o stosunku żywica epoksydowa:piasek 1:20 i 1:30 charakteryzują się bardzo dobrymi właściwościami kapilarnymi dzięki obecności krzemionki koloidalnej, która dodawana w formie zawiesiny wodnej gromadzi się na powierzchni spoiwa żywicznego, nadając mu cechy hydrofilne, oraz dzięki dużym porom tworzącym się wskutek stosowania dużej ilości kruszywa. Spoiwo otacza cienkimi powłoczkami kruszywo, pomiędzy jego ziarnami powstają bardzo małe meniski, dzięki czemu nie następuje znaczące zmniejszenie porów pomiędzy ziarnami.

Dzięki dużej porowatości otwartej hydrofilne zaprawy epoksydowe mają dużą nasiąkliwość wodą wynoszącą około 20\%. Omawiana cecha decyduje także o małym ciężarze objętościowym zapraw.

Wytrzymałość mechaniczna zapraw jest wysoka, lecz w dużym stopniu spada po ich 24-godzinnym nasycaniu w wodzie. Przypuszczano, że powodem małej odporności zapraw na działanie wody jest niedostateczne utwardzenie żywicy epoksydowej, toteż część próbek wygrzano przez 2 godziny w temperaturze $60^{\circ} \mathrm{C}$, a czesść w temperaturze $150^{\circ} \mathrm{C}$ i po zanurzeniu do wody (24 godz.) badano ich wytrzymałość na ściskanie. Stwierdzono, że próbki $1: 20$, wygrzane $w$ temperaturze $60^{\circ} \mathrm{C}$, miały wytrzymałość na ściskanie 16,6 MPa, a więc utraciły w stosunku do suchych, niewygrzewanych, $19,8 \%$ wytrzymałości. Wygrzewane w temperaturze $150^{\circ} \mathrm{C}$ wykazywały wytrzymałość 33,5 MPa (1:20) i 26,7 MPa (1:30), a więc wyższą od próbek suchych, niewygrzewanych, lecz utraciły swoje właściwości hydrofilne. Doświadczenie to wskazuje, że należy poszukiwać bardziej aktywnych utwardzaczy reagujących z żywicą epoksydową w temperaturze pokojowej, aby związać wszystkie grupy epoksydowe żywicy. Zapewni to zwiększenie odporności zapraw na działanie wody. Cechą pozytywną zapraw jest ich bardzo mały skurcz.

\section{Wnioski}

Porównując właściwości hydrofilnych zapraw epoksydowych z postulowanymi właściwościami zapraw do uzupełniania ubytków w piaskowcach Gotland i Obernkirchen, stwierdzono, że mają one jedynie odpowiednie właściwości mechaniczne. 
Bardzo szybkie podciaganie wody przez zaprawy epoksydowe i ich dużą nasiąkliwość należy uznać za cechy niekorzystne.

\subsubsection{Odporność zapraw na działanie siarczanu sodowego}

Badania prowadzono zgodnie z opisem podanym w p. 4, stosując nasycony roztwór siarczanu sodowego. Wyniki zamieszczono w tabeli 29 oraz na ilustracjach 3-6.

\section{Omówienie wyników}

Biorąc pod uwagę opisy zniszczeń w tabeli 29, stwierdzono, że największemu zniszczeniu uległ piaskowiec Gotland, w drugiej i trzeciej kolejności zaprawa epoksydowa 1:20 i 1:30 (podstawy próbek i w jednym przypadku pęnięcie w odległości kilku mm od powierzchni górnej). Największą odpornością na sole charakteryzuje się piaskowiec Obernkirchen.

\subsubsection{Odporność zapraw na zamrażanie}

Po przeprowadzeniu 20 cykli zamrażania i rozmrażania stwierdzono, że jedynie zaprawy epoksydowe uległy zniszczeniom, polegającym na ich pękaniu. Po 5 cyklach pękła jedna z próbek o stosunku spoiwo:kruszywo = 1:20. Po szóstym cyklu pęknięcia pojawiły się w dwóch dalszych próbkach tej serii. W zaprawach o stosunku 1:30 pęknięcia zaobserwowano po szóstym, jedenastym i dwunastym cyklu. Omawiane zniszczenia zapraw po dziesięciu i dwunastu cyklach prezentuje il. 7. Mała odporność zapraw o lepiszczu epoksydowym na zamrażanie jest spowodowana niedostatecznym utwardzeniem żywicy. Piaskowce Gotland i Obernkirchen nie uległy zmianom.

\subsubsection{Przyczepność zapraw do piaskowców}

Przyczepność badano w sposób opisany w p. 4.

\section{Omówienie wyników}

Przyczepność zapraw (tab. 30), szczególnie EP:piasek $=1: 30$, jest bardzo mała, co wynika z małej zawartości żywicy w zaprawie. Zaprawy uzyskują lepszą przyczepność po wstępnym pokryciu powierzchni piaskowców 15\% roztworem żywicy. Wszystkie zaprawy oddzieliły się bez uszkodzeń od po- 
wierzchni piaskowców, co świadczy o tym, że ich wytrzymałość na rozrywanie jest większa niż przyczepność do piaskowców (szczególnie 1:30).

\subsubsection{Odporność zapraw epoksydowych na ścieranie}

Badania przeprowadzono zgodnie z opisem zawartym w p. 4.

\section{Omówienie wyników}

Na podstawie il. 9 prezentującej wyniki stwierdzono, że zaprawy epoksydowe charakteryzują się dużą odpornością na ścieranie, wyższą od badanych piaskowców.

\subsubsection{Podsumowanie wyników badań}

Badania pozwoliły ustalić, że jedynym parametrem hydrofilnych zapraw epoksydowych, który można kształtować, jest ich wytrzymałość na ściskanie. Zaprawy o stosunku 1:20 mają wytrzymałość odpowiednią do tego, aby za ich pomocą uzupełniać ubytki w piaskowcu Obernkirchen, a 1:30 w Gotland. Pozostałych parametrów, takich jak szybkość kapilarnego podciągania wody i nasiąkliwość, nie można regulować. Zaprawy, niezależnie od ilości krzemionki koloidalnej, podciągają wodę znacznie szybciej niż badane piaskowce oraz mają od nich wyższą nasiąkliwość. Te cechy mogą powodować zwiększone zawilgocenie piaskowców podczas opadów deszczu czy w wyniku podciągania wody z ziemi, co oczywiście nie byłoby korzystne. Do mankamentów tych zapraw należy także zaliczyć ich stosunkowo małą odporność na działanie wody (spadek około 40\%), a szczególnie na zamrażanie, oraz mała przyczepność do piaskowców. Odporność na ścieranie jest dobra.

\subsection{Hydrofilne zaprawy o spoiwie polimetakrylanowym}

Biorąc pod uwage pozytywne rezultaty badań nad uzyskaniem hydrofilnych zapraw epoksydowych, postanowiono podjąc próby nadania cech hydrofilnych zaprawom o spoiwie polimetakrylanowym.

W pierwszej fazie zbadano wpływ ilości kruszywa na właściwości zapraw hydrofobowych. W drugiej podjęto badania nad nadaniem zaprawom cech hydrofilnych, a w trzeciej określono ich właściwości fizyczne, mechaniczne i odpornościowe. 
Do badań stosowano polimetakrylan metylu uzyskany na drodze polimeryzacji suspensyjnej (drobnoziarnisty proszek) oraz piasek o granulacji $<0,2 \mathrm{~mm}$. Aby uniknąć czasochłonnego rozpuszczania polimetakrylanu metylu, zaprawy przygotowywano w następujący sposób: piasek mieszano z polimerem, do mieszaniny dodawano (bez mieszania) rozpuszczalnik i mase szczelnie zakrywano, aby uniknąć ulatniania się rozpuszczalnika. W utworzonych warunkach następuje całkowite rozpuszczenie się polimeru i zaprawa po 24 godzinach jest gotowa do użycia ${ }^{17}$.

Jako rozpuszczalnik stosowano mieszaninę ( $1: 1)$ chlorku etylenu z alkoholem etylowym. Na 1 część wagową polimeru stosowano 1,5 części objętościowej rozpuszczalnika.

\subsubsection{Określenie właściwości zapraw niezwiązanych}

Otrzymane w powyższy sposób zaprawy, zawierające od 5 do 15 części kruszywa w stosunku do żywicy, cechuje wysoka plastyczność. Należy to przypisać dużej lepkości roztworu, uzyskanemu dzięki wysokiemu stężeniu żywicy (40\%). Ze względu na fizyczny proces twardnienia zapraw (ulatnianie się rozpuszczalnika) ilość kruszywa, jaką można zmieszać z żywica, nie może być dowolna i mieści się w wąskich granicach. Przy zbyt małej ilości kruszywa nadmiar spoiwa gromadzący się na powierzchni zaprawy utrudnia jej twardnienie (wysychanie). Górną granice ilości kruszywa ogranicza jedynie wytrzymałość zapraw.

Zaprawy mają dobrą przyczepność do pionowych powierzchni piaskowców i można je kształtować plastycznie.

Czas pracy z zaprawami zawierającymi lotne rozpuszczalniki był krótki i wynosił około 10 minut. Wymienione rozpuszczalniki stosowano, aby przyspieszyć proces twardnienia próbek o przekroju $4 \mathrm{~cm} \times 4 \mathrm{~cm}$. Użycie mniej lotnych rozpuszczalników powodowało, że czas twardnienia był długi, co spowalniało prowadzone badania.

17 Ibidem, s. 155. 


\subsubsection{Wpływ ilości piasku na właściwości zapraw bez dodatków hydrofilnych}

Celem badań było ustalenie optymalnej ilości kruszywa warunkującej wysychanie i twardnienie zapraw oraz określenie ich odpowiedniej wytrzymałości mechanicznej.

\section{Omówienie wyników}

Stosując 5 i 7,5 cześci kruszywa w stosunku do polimeru (tab. 31), uzyskuje się zaprawy źle wysychające. Przyczyna jest nadmiar spoiwa, które tworzy na powierzchni zaprawy skorupkę (żel) utrudniającą ulatnianie się rozpuszczalnika. Pozostałe zaprawy wysychały dobrze i bez skurczu. Jak wynika z tabeli, zaprawy doskonale podciagają benzynę lakową, a ich nasiąkliwość jest zbliżona do nasiąkliwości badanych piaskowców lub wyższa.

Wytrzymałość zapraw na ściskanie jest zbliżona do postulowanej dla zapraw do uzupełniania ubytków w piaskowcu Obernkirchen.

Opisane działania pozwoliły wyrazić przypuszczenie o celowości kontynuowania badań.

\subsubsection{Badanie możliwości nadania zaprawom PMM właściwości hydrofilnych}

Stosowano stały stosunek polimetakrylan metylu:piasek:rozpuszczalnik = $=1: 15: 1,5$. Rozpuszczalnik stanowiła mieszanina chlorku etylenu i alkoholu etylowego 1:1. Aby uzyskać zaprawy o właściwościach hydrofilnych, użyto jako dodatku krzemionki koloidalnej. Stosowano ją w postaci suchej, zawiesiny w wodzie lub w rozpuszczalniku, mieszano ją z polimerem, piaskiem i zalewano rozpuszczalnikiem lub też dodawano ją do zaprawy po 24 godzinach, tzn. po rozpuszczeniu się żywicy. Krzemionkę stosowano w różnych stężeniach. Doświadczenia miały na celu wybór zapraw o najlepszych właściwościach kapilarnych i mechanicznych.

Poszczególne składniki mieszano w następujący sposób:

a) 1 cz. polimeru mieszano z 0,01 cz. krzemionki koloidalnej, z piaskiem, a następnie zalewano mieszaninę rozpuszczalnikiem;

b) jak „a” + 0,025 cz. krzemionki; 
c) polimer mieszano z 10\% zawiesiną wodną krzemionki koloidalnej $(0,1 \mathrm{cz} . \mathrm{w}$ stosunku do polimeru), z piaskiem, a następnie zalewano mieszaninę rozpuszczalnikiem;

d) polimer mieszano z piaskiem, zalewano rozpuszczalnikiem i mieszano z 10\% zawiesiną krzemionki koloidalnej w wodzie $(0,25$ cz. w stosunku do polimeru);

e) jak „d” + 2,5\% zawiesina krzemionki koloidalnej (1,0 cz. w stosunku do polimeru);

f) polimer mieszano z piaskiem, zalewano mieszaninę rozpuszczalnikiem, a po 24 godzinach dodawano 10\% zawiesinę krzemionki koloidalnej w wodzie $(0,25$ cz. $)$ i całość mieszano;

g) jak „f” $+0,5$ cz. 10\% zawiesiny krzemionki koloidalnej;

h) jak „f” $+1,0$ cz. 10\% zawiesiny krzemionki koloidalnej;

i) jak „f” $+1,0$ cz. 2,5\% zawiesiny krzemionki koloidalnej;

j) polimer mieszano z piaskiem, zalewano mieszaninę $1,25 \mathrm{cz}$. rozpuszczalnika, a po 24 godzinach dodawano 0,25 cz. rozpuszczalnika zmieszanego z krzemionką koloidalną i całość mieszano.

Wyniki przedstawiono w tabeli 32.

\section{Omówienie wyników}

Jak wynika z tabeli 32, bezpośrednie mieszanie krzemionki koloidalnej z polimerem, suchej bądź w zawiesinie wodnej, nie nadało zaprawom właściwości hydrofilnych ( „a" - „, 24 godzinach, zawiesinę krzemionki w rozpuszczalniku organicznym (,j”). W przeciwieństwie do omówionych, wszystkie zaprawy, które otrzymano, dodając zawiesinę krzemionki koloidalnej w wodzie do mieszaniny polimeru, piasku i rozpuszczalnika („d”-,„i”), mają dobre właściwości kapilarne, lecz różnią się wytrzymałością na ściskanie. Najlepsze właściwości mechaniczne ma zaprawa "d”, którą otrzymano, dodając 0,25 cz. (na 1 cz. polimeru) 10\% zawiesiny krzemionki koloidalnej w wodzie do mieszaniny polimeru, piasku i rozpuszczalnika bezpośrednio po wymieszaniu składników. Przy zwiększeniu ilości wody do l części, pomimo że użyto tej samej ilości krzemionki, nastąpił gwałtowny spadek wytrzymałości (zaprawa „e"). Wszystkie zaprawy, które uzyskano, dodając krzemionkę koloidalną do mieszanin po 24 godzinach („f”-„i”), odznaczają się dobrymi właściwościami kapilarny- 
mi, lecz mają niską wytrzymałość mechaniczną. Przyczyną tego są trudności wymieszania krzemionki z mieszaniną, która uzyskuje po tym okresie dużą lepkość wskutek rozpuszczenia się żywicy. Wprowadzenie zawiesiny wodnej krzemionki bezpośrednio po wymieszaniu polimeru z piaskiem i zalaniu ich rozpuszczalnikiem jest znacznie łatwiejsze, aczkolwiek uzyskanie jednorodnych mieszanin także przysparza trudności (mieszano składniki ręcznie za pomocą szpachli).

\section{Wnioski}

W przypadku dodawania zawiesiny krzemionki koloidalnej w wodzie do zaprawy polimer-piasek-rozpuszczalnik, na powierzchni spoiwa polimerowego osadza się, podobnie jak w przypadku żywicy epoksydowej, krzemionka koloidalna, nadając zaprawie właściwości hydrofilne. Nie można tego efektu uzyskać przez dodanie suchej krzemionki do omawianej mieszaniny lub też stosowanie zawiesiny w rozpuszczalniku organicznym. Aby otrzymać zaprawy hydrofilne, należy wykorzystywać zawiesiny w cieczach niemieszających się z rozpuszczalnikiem żywicy.

\subsubsection{Hydrofilna zaprawa polimetakrylanowa o optymalnych właściwościach}

Biorąc pod uwagę uzyskane wyniki, do badań właściwości fizycznych, mechanicznych i odporności na czynniki niszczące wybrano zaprawę „d” (tab. 32).

Badano właściwości kapilarne zapraw, stopień nasycenia wodą po 6 godzinach nasycania kapilarnego, nasiąkliwość wodą po 24 godzinach zanurzenia, wytrzymałość na ściskanie, odporność na działanie siarczanu sodowego (test solny) i na zamrażanie oraz przyczepność zapraw do piaskowców.

\subsubsection{Określenie fizycznych i mechanicznych właściwości zaprawy} Badania przeprowadzono zgodnie z opisem zamieszczonym w p. 4.

\section{Omówienie wyników}

Jak wynika z tabeli 33, zaprawa charakteryzuje się małym ciężarem objętościowym i skurczem, ma postulowaną w stosunku do piaskowca Gotland nasiąkliwość i wytrzymałość na ściskanie. Do wad należy zaliczyć znaczny spadek wytrzymałości zaprawy po nasycaniu wodą. 
Należy podkreślić, że stosunek polimer:piasek należy także do optymalnych. Przy zwiększaniu ilości piasku następuje spadek wytrzymałości. Przy jego zmniejszaniu natomiast wytrzymałość rośnie, lecz zaprawy wskutek obecności większej ilości spoiwa trudno wysychają, gdyż na ich powierzchni tworzy się żel uszczelniający pory.

\subsubsection{Odporność zapraw na działanie siarczanu sodowego}

Badania prowadzono zgodnie z opisem podanym w p. 4, stosując nasycony roztwór siarczanu sodowego. Wyniki zamieszczono w tabeli 34 oraz na ilustracjach 3-6.

\section{Omówienie wyników}

Odporność zapraw polimetakrylanowych na działanie siarczanu sodowego jest większa od piaskowca Gotland, lecz mniejsza od Obernkirchen. Zniszczeniu uległy przede wszystkim podstawy próbek, w miejscach podparcia szklanymi prętami.

\subsubsection{Odporność zapraw na zamrażanie}

Badaniom poddano zaprawę o składzie PMM:piasek = 1:15 (tab. 33).

\section{Omówienie wyników}

Po 20 cyklach zamrażania i rozmrażania nie zaobserwowano objawów zniszczeń zapraw (il. 7).

\subsubsection{Przyczepność zapraw do piaskowców}

Przyczepność badano w sposób opisany w p. 4. Analizom poddano zaprawę o składzie PMM:piasek = 1:15 (tab. 33).

\section{Omówienie wyników}

Zaprawy (tab. 35) mają bardzo małą przyczepność do piaskowców, która wzrasta po wstępnym pokryciu ich powierzchni 10\% roztworem polimetakrylanu metylu. Zaprawy oddzieliły się bez uszkodzeń od nieprzeklejonych powierzchni piaskowców, co świadczy o tym, że ich wytrzymałość na rozrywanie jest większa niż przyczepność do piaskowców. Na piaskowcach przeklejonych pozostały rozproszone niewielkie skupiska zaprawy, co może 
dowodzić, że ich wytrzymałość na rozrywanie jest zbliżona do ich przyczepności do kamieni.

8.2.4.5. Odporność zaprawy polimetakrylanowej na ścieranie Badania przeprowadzono zgodnie z opisem w p. 4.

\section{Omówienie wyników}

Na podstawie il. 9 prezentującej wyniki stwierdzono, że zaprawy polimetakrylanowe charakteryzują się dużą odpornością na ścieranie, nieco mniejszą od badanych piaskowców.

\subsubsection{Podsumowanie wyników badań}

Na podstawie przeprowadzonych badań stwierdzono, że aby uzyskać zaprawy polimetakrylanowe z piaskiem o granulacji $<0,20 \mathrm{~mm}$, stosunek spoiwo: :kruszywo nie powinien być mniejszy od 1:15. Zaprawy takie twardnieja bez przeszkód, niezależnie od masy i objętości, wskutek ulatniania się rozpuszczalników. Zwiększenie ilości kruszywa nie jest celowe, gdyż następuje zbyt duży spadek wytrzymałości na ściskanie. Zaprawy o podanym stosunku mają odpowiednią wytrzymałość mechaniczna, aby można je było stosować do uzupełniania ubytków w piaskowcu Gotland, ale na przeszkodzie stoi ich zbyt szybkie kapilarne podciaganie wody. Właściwość ta, podobnie jak w przypadku zapraw epoksydowych, może przyczyniać się do nadmiernego zawilgacania piaskowców.

\section{Podsumowanie wniosków wynikających z badań nad technologią zapraw do uzupełniania ubytków w piaskowcach Gotland i Obernkirchen}

Prowadzono badania nad technologia zapraw o spoiwach mineralnych i organicznych (polimerowych). W pierwszej fazie określono właściwości fizyczne i mechaniczne piaskowców i na tej podstawie ustalono parametry, jakimi powinny charakteryzować się zaprawy. Za najważniejsze uznano ich właściwości kapilarne i wytrzymałość na ściskanie zbliżone do piaskowców (tab. 1). 
Należy podkreślić, że świadomie założono, aby właściwości kapilarne zapraw przeznaczonych do uzupełniania ubytków w piaskowcu Gotland były nieco niższe od średnich właściwości, jakie maja próbki „zdrowego” kamienia. W badaniach stwierdzono, że 95-procentowy stopień nasycenia uzyskiwały próbki średnio po 2 godzinach, a nie, jak się postuluje, po 6 godzinach. Decyzja taka wynika z niemożliwości otrzymania zapraw mineralnych o wysokich parametrach mechanicznych, dobrych właściwościach kapilarnych i jednocześnie niskiej nasiąkliwości jak w przypadku piaskowca Gotland. Wskaźniki te wykluczają się wzajemnie.

Postulowane właściwości kapilarne zapraw do uzupełniania ubytków w piaskowcu Obernkirchen są zgodne z właściwościami kapilarnymi tego piaskowca.

Zakładano, że wytrzymałości na ściskanie zapraw mogą być znacznie mniejsze od wytrzymałości omawianych piaskowców, ponieważ kamienie w obiektach zabytkowych mają niższe wytrzymałości mechaniczne wskutek zachodzących procesów niszczenia. Zaprawy te powinny jednak mieć wystarczającą wytrzymałość, aby nie poddawać się szkodliwym działaniom czynników zewnętrznych. Założenie to jest zgodne z postulatem konserwatorskim, stwierdzającym, że materiały stosowane do uzupełniania ubytków muszą mieć niższe właściwości mechaniczne od kamieni uzupełnianych oraz zbliżone właściwości kapilarne.

Zbadano właściwości mineralnych zapraw fabrycznych oraz zapraw otrzymanych na podstawie receptur własnych. Stosując różną ilość piasku, zbadano cechy zapraw z cementami portlandzkimi. Określono wpływ ilości wody na właściwości zapraw oraz dodatków modyfikujących: metakaolinitu, krzemionki koloidalnej, wapna hydratyzowanego, metylohydroksyetylocelulozy. Poza wymienionymi zbadano właściwości zapraw o spoiwach polimerowych, używając żywicy epoksydowej Epidian 5 i polimetakrylanu metylu otrzymanego na drodze polimeryzacji suspensyjnej.

Jako kruszywo stosowano piasek szklarski o granulacji przechodzącej przez sito $0,20 \mathrm{~mm}$, co odpowiada strukturze badanych piaskowców, oraz drobno zmielone piaskowce i mączki: kwarcowe i marmurową. Należy podkreślić, że w swojej praktyce naukowo-konserwatorskiej autor opracowania nie prowadził badań nad technologią zapraw z tak drobnoziarnistymi kruszywami, stąd jego eksperymenty miały charakter pionierski. 


\subsection{Omówienie wyników badań}

Oceniając przydatność zapraw do uzupełniania ubytków w piaskowcach, brano pod uwage ich właściwości kapilarne, wytrzymałość na ściskanie, nasiąkliwość wodą, odporność na wodę i skurcz.

Podejmując badania, zakładano, że stosując spoiwo o wysokiej wytrzymałości (cement marki 52,5, żywica epoksydowa, polimetakrylan metylu), będzie można przeprowadzić regulację właściwości fizycznych i mechanicznych zapraw, dawkując odpowiednie ilości kruszywa.

\subsubsection{Zaprawy mineralne}

- Zaprawy dostarczone przez firmy Remmers i Keim (Niemcy) oraz Atlas (Polska). Mają one żądaną wytrzymałość i nasiąkliwość wodą, jednak złe właściwości kapilarne.

- Zaprawy z cementem 52,5 i piaskiem. Stosując biały cement, przy stosunku cement:piasek $=1: 4$ i 1:5, uzyskano zaprawy o zbliżonych parametrach do postulowanych. Zaprawy z cementem szarym oraz mieszaniną cementu białego i szarego mają gorsze właściwości kapilarne od zapraw z cementem białym.

- Zaprawy cementowe ze zmienną ilością wody zarobowej. Zwiększenie ilości wody zarobowej o 10\% i 20\% nie przyniosło poprawy właściwości kapilarnych zapraw. Woda, plastyfikując zaprawy, pozwala na lepsze ich zagęszczenie, czego przejawem jest wzrost ich ciężaru objętościowego i pewne pogorszenie ich właściwości kapilarnych. Dalsze zwiększanie ilości wody jest niecelowe, ponieważ zaprawy tracą swą konsystencje plastyczną.

- Zaprawy cementowe modyfikowane metakaolinitem. Stosowane dodatki pogarszają właściwości kapilarne zapraw, nie polepszając ich wytrzymałości mechanicznej.

- Zaprawy cementowe modyfikowane krzemionką koloidalną. Krzemionka koloidalna polepsza właściwości kapilarne zapraw, jednak obniża ich wytrzymałość mechaniczną. Zaprawa cement:piasek $=1: 4$, zawierająca 2,5\% dodatek krzemionki koloidalnej, ma odpowiednie właściwości kapilarne i wytrzymałość mechaniczną, jakie postulowano 
dla zapraw do uzupełniania ubytków w piaskowcu Obernkirchen. Zaprawy z większą ilością krzemionki wykazują zbyt małą wytrzymałość.

- Zaprawy cementowe modyfikowane metakaolinitem i krzemionka koloidalna. Zaprawy o odpowiedniej wytrzymałości nie mają dobrych właściwości kapilarnych.

- Zaprawy cementowe modyfikowane metylohydroetylocelulozą. Jej dodatki bardzo pogarszają właściwości kapilarne zapraw i obniżają ich wytrzymałość na ściskanie.

- Zaprawy cementowe modyfikowane wapnem hydratyzowanym. Przy stosunku cement:wapno:piasek = 1,5:0,5:7 zaprawy mają zbliżone właściwości kapilarne do zapraw postulowanych do uzupełniania ubytków w piaskowcu Obernkirchen, lecz niższą wytrzymałość, a zaprawy o stosunku 1:1:4 mają odpowiednie właściwości mechaniczne dla uzupełniania ubytków w piaskowcu Gotland, wykazują jednak gorszą kapilarność i zbyt wysoką nasiąkliwość woda.

- Zaprawy cementowe modyfikowane dyspergowanym wapnem hydratyzowanym. Zaprawy $\mathrm{z}$ dodatkami wapna dyspergowanego maja gorsze właściwości kapilarne niż zaprawy z wapnem hydratyzowanym niedyspergowanym.

- Zaprawy cementowe z kruszywem z piaskowców Gotland i Obernkirchen o granulacji $>0,125 \mathrm{~mm}$. Dodatki zmielonych piaskowców nie polepszyły właściwości kapilarnych zapraw ani też ich wytrzymałości mechanicznej. Wzrosła natomiast o około 100\% ich nasiąkliwość wodą w stosunku do zapraw z piaskiem o granulacji $0,20 \mathrm{~mm}$.

- Zaprawy cementowe z dodatkami mączki kwarcowej i marmurowej. Dodatki mączek pogarszają właściwości kapilarne zapraw cementowych. Na uwagę zasługuje jednak mączka kwarcowa o granulacji $40 \mu \mathrm{m}$, która w bardzo dużym stopniu zwiększa wytrzymałość zapraw na ściskanie (2,0-2,5 razy). Stosując na 1 część cementu 1,5 części mączki oraz 7 i 6,5 części piasku, uzyskano zaprawy, które mają zbliżone właściwości do zapraw postulowanych do uzupełniania ubytków w badanych piaskowcach. 


\subsubsection{Zaprawy o spoiwach organicznych}

- Zaprawy epoksydowe. Dodatki krzemionki koloidalnej pozwoliły uzyskać hydrofilne zaprawy epoksydowe o stosunku żywica:piasek od 1:10 do 1:30. Niestety, właściwości ich odbiegają od postulowanych parametrów dla zapraw przeznaczonych do uzupełniania ubytków w piaskowcach Gotland i Obernkirchen. W przeciwieństwie do zapraw mineralnych bardzo szybko podciagają wodę na drodze kapilarnej i wykazują bardzo dużą nasiąkliwość wodą, która rośnie wraz z ilością kruszywa, przy jednocześnie zbyt wysokiej wytrzymałości na ściskanie.

- Zaprawy polimetakrylanowe. Stosując roztwory polimetakrylanu metylu i dodatki krzemionki koloidalnej, otrzymano hydrofilne zaprawy, wiążące $\mathrm{w}$ warstwach o dowolnej grubości. Ze względu na fizyczny mechanizm twardnienia, używając kruszywa o granulacji $<0,20 \mathrm{~mm}$, można w praktyce stosować zaprawę o stosunku żywica:piasek $=1: 15$. Zaprawa ma zbliżone właściwości do postulowanych dla obydwu badanych piaskowców. Charakteryzuje się jednak gorszymi właściwościami kapilarnymi od zapraw dla piaskowca Gotland i niższą wytrzymałością mechaniczną od zapraw dla piaskowca Obernkirchen.

\subsection{Wnioski wynikające z badań}

Przeprowadzone badania pozwolity na opracowanie technologii zapraw przeznaczonych do uzupełniania ubytków w piaskowcach Gotland i Obernkirchen. Starano się uzyskać zaprawy o zbliżonych parametrach do poszczególnych piaskowców (właściwości kapilarne, nasiąkliwość wodą, struktura) oraz o niższej wytrzymałości mechanicznej od „zdrowych” piaskowców, jednak gwarantującej odporność zapraw na działanie niszczących czynników zewnętrznych.

\subsubsection{Zaprawy cementowe}

W celu nadania zaprawom struktury zbliżonej do piaskowców zachodziła konieczność stosowania kruszywa drobnoziarnistego, co utrudniało otrzymanie zapraw cementowych o postulowanych właściwościach. Zaprawy z takim kruszywem odznaczają się zwiększoną porowatością, lecz złymi właściwościami kapilarnymi (tworzą się kapilary o małych średnicach). 
Wraz ze zwiększaniem ilości kruszywa rosła nasiąkliwość zapraw i malała ich wytrzymałość, a w małym stopniu polepszały się właściwości kapilarne. Nieliczne zaprawy o postulowanych parametrach uzyskano dzięki zastosowaniu cementu wysokiej marki (52,5), co umożliwiło dodawanie dużych ilości piasku, a także dzięki dodatkom krzemionki koloidalnej, wapna hydratyzowanego i mączki kwarcowej.

W przypadku omawianych zapraw o ich właściwościach kapilarnych decyduje spoiwo cementowe, które wypełnia „pustki” pomiędzy ziarnami kruszywa. Tworzy ono tzw. spoiwo bazalne o drobnoporowatej strukturze warunkującej kapilarność zapraw. Regulacja tej struktury jest bardzo trudna, gdyż cementy wysokiej marki są z natury rzeczy drobnoziarniste, a także są nimi stosowane przez nas kruszywa i dodatki modyfikujące. Pomimo to, wraz ze zwiększeniem ilości kruszywa, obserwowano polepszanie właściwości kapilarnych zapraw cementowych, co niewątpliwie miało swoje źródło w zmniejszaniu się otoczek spoiwa na ziarnach piasku i tworzeniu się między nimi większych porów. Uzyskiwanie zapraw o pożądanej kapilarności było jednak w większości przypadków ograniczone gwałtownym spadkiem ich wytrzymałości mechanicznej.

Spośród licznych zapraw, jakie zbadano, postulowane właściwości kapilarne mają zaprawy cementowe z piaskiem (1:4 i 1:5), cementowe z piaskiem i krzemionką koloidalną (1:4:0,025), cementowe z piaskiem i wapnem hydratyzowanym (1:4:1), cementowe z piaskiem i mączką kwarcową $40 \mu \mathrm{m}$ (1:7:1 i 1:6,5:1,5). Te ostatnie wydają się najbardziej interesujące.

Pozostałe zaprawy odznaczają się równie ciekawymi parametrami i jedynie ich gorsze właściwości kapilarne stoją na przeszkodzie ich użycia do uzupełniania ubytków w piaskowcach Gotland i Obernkirchen. Mogą być natomiast zastosowane do innego rodzaju kamieni.

\subsubsection{Zaprawy polimerowe}

Przeprowadzone przed kilku laty doświadczenia pozwoliły na otrzymanie hydrofilnych zapraw epoksydowych o dobrych właściwościach mechanicznych ${ }^{18}$. Wyniki te stanowiły zachęte do podjęcia eksperymentów zarówno

18 W. Domasłowski, Spoinowanie murów ceglanych, s. 80. 
z żywicą epoksydową, jak i z polimetakrylanem metylu. Doświadczenia powiodły się i uzyskano zaprawy z tymi spoiwami o bardzo dobrych właściwościach mechanicznych oraz kapilarnych dzięki zastosowaniu krzemionki koloidalnej jako dodatku hydrofilnego. Niestety, w przeciwieństwie do zapraw cementowych, zaprawy polimerowe podciągaja kapilarnie wode znacznie szybciej od piaskowców Gotland i Obernkirchen, co także jest niekorzystne. Użyte do uzupełniania ubytków powodowałyby nadmierne ich zawilgocenie. Działałyby na zasadzie gąbek szybko chłonących wodę i nawilżających kamień.

Fakt szybkiego podciągania wody przez zaprawy polimerowe jest spowodowany występowaniem w nich spoiwa typu kontaktowego. Żywica osadza sie na ziarnach kruszywa w postaci cienkich błonek i skleja je, tworząc małe „meniski”, dzięki czemu powstają duże pory, których średnice są zależne od ilości użytego piasku i jego frakcji. Ze względu na konieczność stosowania dużych ilości piasku (aby obniżyć wytrzymałość mechaniczną zapraw) w zaprawach tworzą się duże pory, w związku z czym zaprawy szybko podciagają wode.

W przypadku zapraw epoksydowych istnieje możliwość regulacji ich wytrzymałości mechanicznej, porowatości i nasiąkliwości wodą praktycznie w dowolnych granicach. Stosując jako spoiwo polimetakrylan metylu, nie można regulować tych parametrów. Ilość kruszywa, jaką można dodać do spoiwa, jest zależna ściśle od wielkości jego ziaren. Istnieje optymalny stosunek, przy którym rozpuszczalniki swobodnie ulatniają się i zaprawy twardnieją. Przy zbyt małej ilości kruszywa tworzy się w powierzchniowych porach zaprawy żel utrudniający jej twardnienie, a przy zbyt dużej - z zapraw swobodnie odparowują rozpuszczalniki, ale są one słabe.

Biorąc pod uwage właściwości zapraw polimerowych, można zaproponować ich stosowanie do wypełniania rys i spękań oraz uzupełniania niewielkich, płytkich ubytków w omawianych piaskowcach. Wykazują one dobra przyczepność (po przeklejeniu kamienia), wiążą w warstwach o dowolnej grubości. Ponieważ zaprawy polimetakrylanowe z użytymi przez nas rozpuszczalnikami wysychają bardzo szybko, można zastąpić je mniej lotnym rozpuszczalnikiem, a mianowicie cykloheksanonem.

Biorąc z kolei pod uwagę właściwości kapilarne, wysoką porowatość i nasiąkliwość zapraw epoksydowych, można postulować stosowanie ich jako 
tynków odsalających, szczególnie w przypadku, gdy korzystniejsze jest wykorzystywanie zapraw bezwodnych (silne zasolenie obiektu, jego wrażliwość na wodę).

\subsection{Proponowane zaprawy do uzupełniania ubytków w piaskowcach Gotland i Obernkirchen}

\subsubsection{Zaprawy do uzupełniania ubytków o postulowanych właściwościach kapilarnych i mechanicznych}

W tabeli 36 zestawiono właściwości spełniające sformułowane postulaty dla zapraw przeznaczonych do uzupełniania ubytków w piaskowcach Gotland i Obernkirchen.

Spośród sześciu zapraw wyróżniono zaprawę nr 1 przeznaczoną do uzupełniania ubytków w piaskowcu Gotland i nr 4 w piaskowcu Obernkirchen. Zaprawy te, składające się z cementu, mączki kwarcowej i piasku, odznaczaja się najlepszymi właściwościami kapilarnymi i zbliżoną do postulowanej wytrzymałością na ściskanie, mają bardzo dobrą przyczepność do piaskowców, mrozoodporność, odporność na sole oraz na ścieranie. Na uwage zasługuje także fakt, że zaprawy te zawieraja zaledwie 11\% cementu i 89\% kwarcu, dzięki czemu ich współczynnik rozszerzalności powinien być zbliżony do współczynnika piaskowców. Należy także przypuszczać, że wydzielający się w czasie hydratacji cementu wodorotlenek wapnia tworzy z mączką kwarcową krzemian wapnia (stąd duży wzrost wytrzymałości na ściskanie), a więc nie wystąpi niekorzystna migracja wodorotlenku wapnia.

Także pozostałe zaprawy są godne uwagi. Cementowe (nr 2 - Gotland; nr 6 - Obernkirchen) wykazują nieco gorsze właściwości kapilarne od zawierających mączkę kwarcową, lecz lepsze właściwości mechaniczne, są prostsze w wykonaniu i tańsze. Są one odporne na zamrażanie, charakteryzują się odpornościa na działanie soli zbliżoną do badanych piaskowców, mają dobra przyczepność (nr 6 - gorszą) do piaskowca Gotland i słabą do Obernkirchen oraz zbliżoną do piaskowców odporność na ścieranie.

Pozostałe zaprawy, z dodatkami krzemionki koloidalnej (nr 5) oraz wapna hydratyzowanego (nr 3), także spełniają postulaty dotyczące kapilarności i wytrzymałości na ściskanie i można ich użyć do uzupełniania ubytków w piaskowcu Obernkirchen (nr 3 do piaskowców o osłabionej wytrzymałości). 


\subsubsection{Zaprawy do uzupełniania ubytków konstrukcyjnych}

W przypadku konieczności uzupełniania ubytków konstrukcyjnych, a więc wymagających zapraw o podwyższonej wytrzymałości mechanicznej, proponuje się zaprawy zestawione w tabeli 37.

Zaprawy nr 1, 2 i 3, o różnym składzie, mają zbliżone właściwości. Zaprawa nr 4 natomiast wykazuje zbliżone do nich właściwości kapilarne, lecz o prawie 70\% większą wytrzymałość na ściskanie.

\subsubsection{Zaprawy do uzupełniania cienkich warstewek powierzchniowych piaskowców}

W przypadku konieczności wypełniania ubytków cienkich, o niewielkiej powierzchni, rys i spękań proponuje się użycie hydrofilnej zaprawy polimetakrylanowej (tab. 38).

Przy stosunku żywica:kruszywo = 1:15 zaprawa twardnieje $\mathrm{w}$ warstwach o dowolnej grubości (a więc bardzo cienkich i grubych), a jej wykonanie jest bardzo proste. Spoiwo nie zmienia w znaczącym stopniu zabarwienia kruszywa i dlatego celowe jest stosowanie jako kruszyw zmielonych i przesianych do odpowiedniej granulacji $(0,20 \mathrm{~mm})$ piaskowców. Ponieważ zaprawy z wykorzystywanymi w badaniach rozpuszczalnikami bardzo szybko schną i ich żywotność (czas pracy) jest bardzo krótka, proponuje się stosowanie jako rozpuszczalnika cykloheksanonu. 
[141]

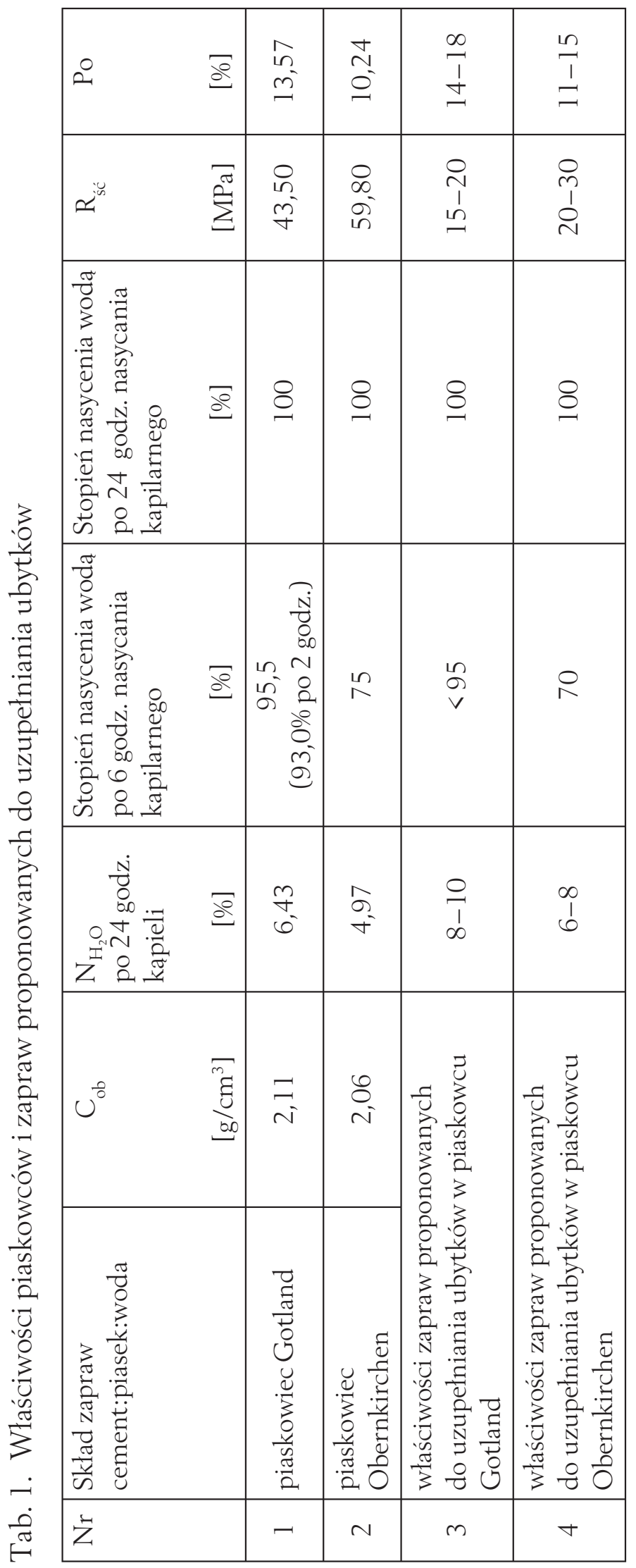




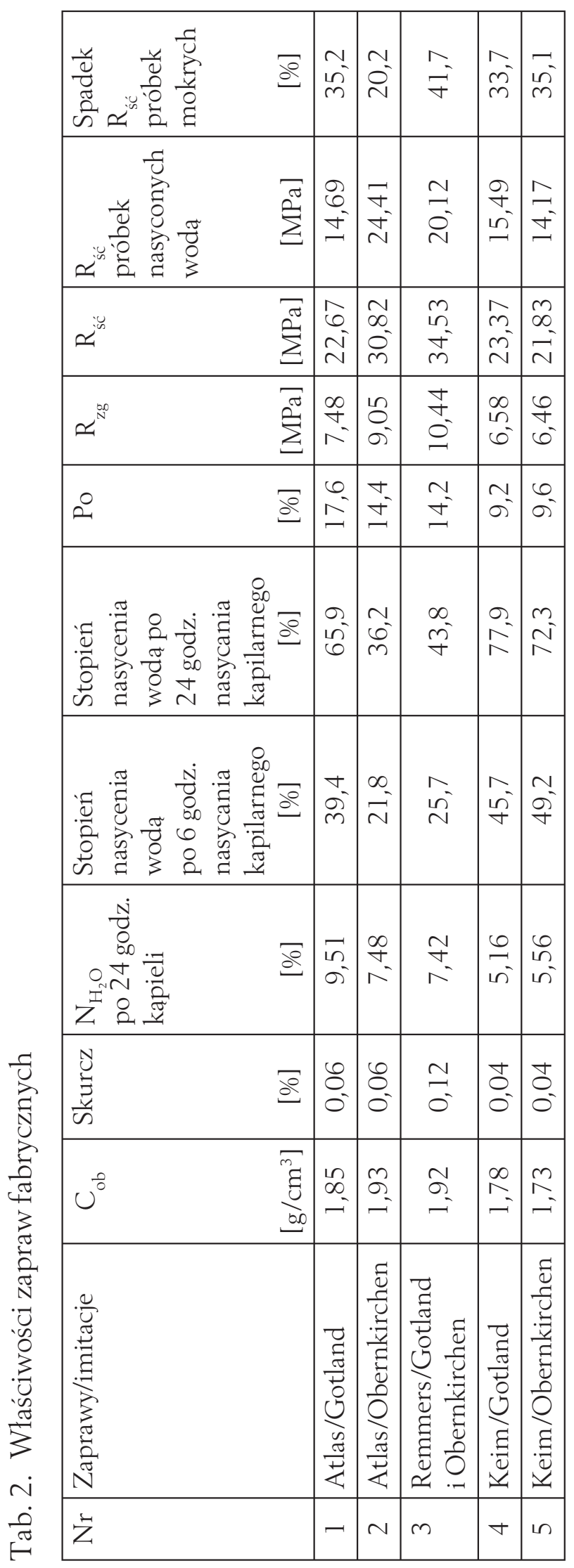

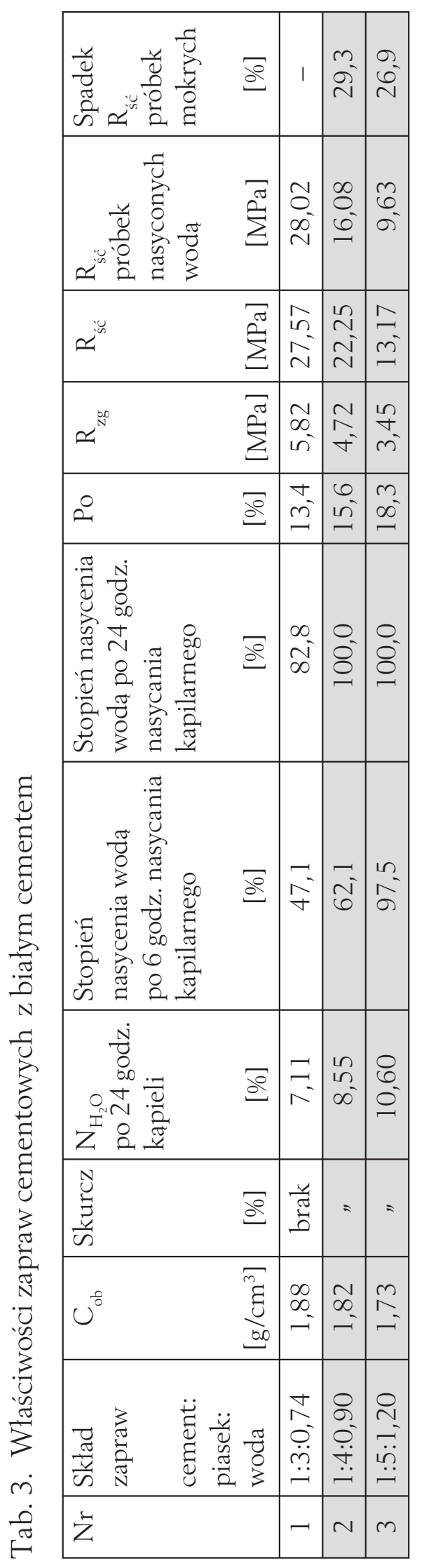


[143]

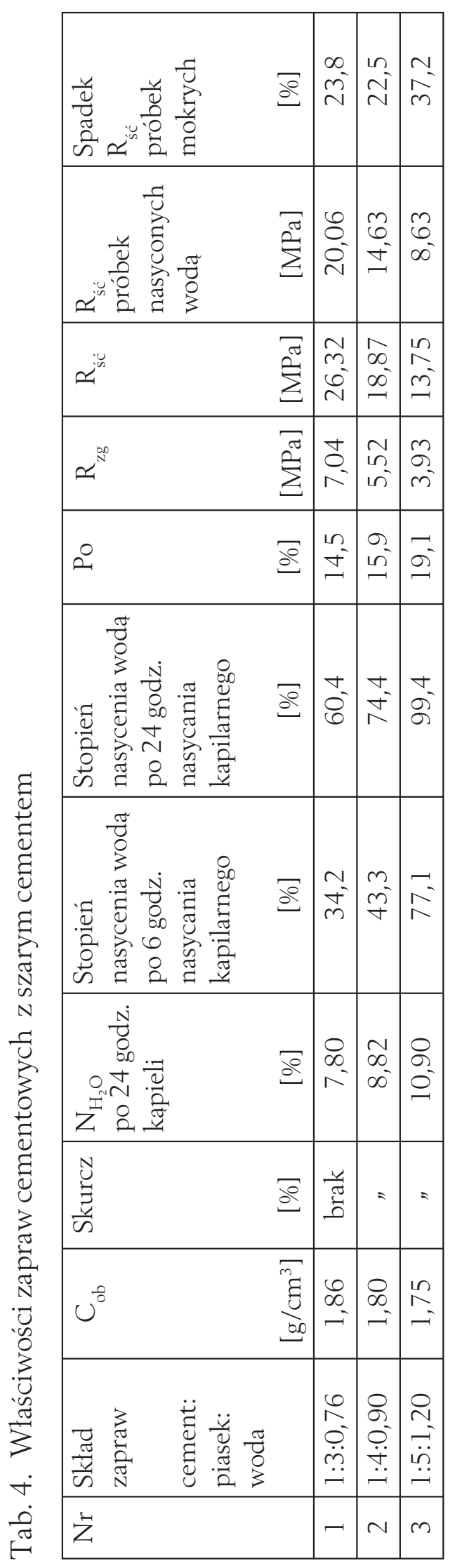

\begin{tabular}{|c|c|c|}
\hline 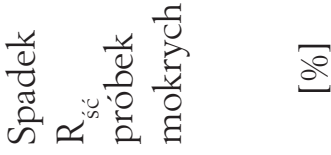 & $\begin{array}{l}\stackrel{0}{\sim} \\
\stackrel{\sim}{\sim}\end{array}$ & \begin{tabular}{l}
$\infty$ \\
\multirow{N}{N}{}
\end{tabular} \\
\hline 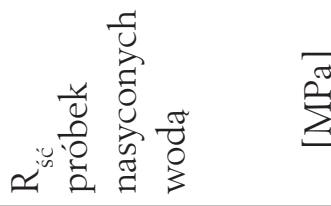 & $\begin{array}{l}\text { o } \\
\text { ì }\end{array}$ & $\begin{array}{l}\stackrel{0}{m} \\
\stackrel{-}{n}\end{array}$ \\
\hline$\simeq^{i, n}$ & $\begin{array}{l}8 \\
0 \\
6\end{array}$ & $\begin{array}{l}\infty \\
2 \\
6 \\
0\end{array}$ \\
\hline$\simeq^{500}$ & $\stackrel{i n}{\sim}$ & $\begin{array}{l}\tilde{O} \\
i n\end{array}$ \\
\hline$\stackrel{0}{2}$ & $\begin{array}{l}0 \\
N\end{array}$ & $\begin{array}{l}0 \\
0 \\
-\end{array}$ \\
\hline 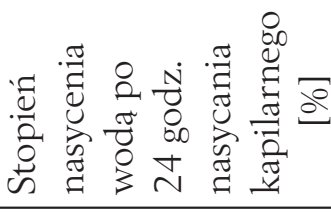 & $\begin{array}{l}\forall \\
\dot{n}\end{array}$ & $\vec{\sigma}$ \\
\hline 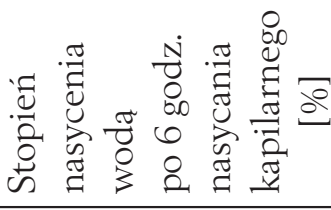 & $\hat{\sigma}$ & $\stackrel{m}{\tilde{b}}$ \\
\hline 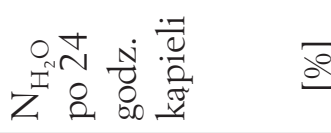 & $\begin{array}{l}\infty \\
\frac{1}{\infty} \\
\sigma^{2}\end{array}$ & $\frac{10}{a}$ \\
\hline 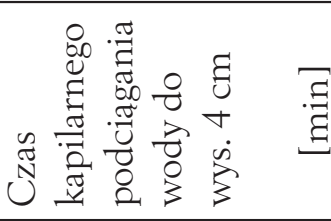 & $\stackrel{m}{\sim}$ & $\stackrel{\infty}{\underset{N}{N}}$ \\
\hline 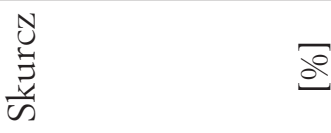 & $\begin{array}{l} \pm \\
0 \\
0\end{array}$ & $\begin{array}{l}10 \\
0 \\
0\end{array}$ \\
\hline$u^{0}$ & $\begin{array}{l}\infty \\
\infty \\
-\end{array}$ & $\stackrel{\infty}{-}$ \\
\hline 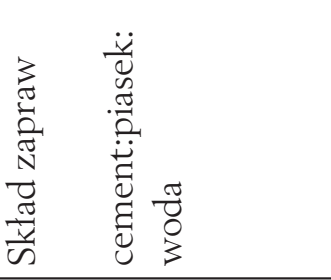 & 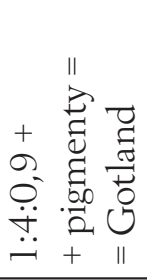 & 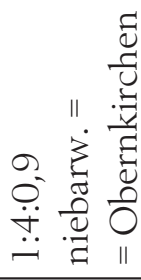 \\
\hline$\grave{Z}$ & - & $N$ \\
\hline
\end{tabular}



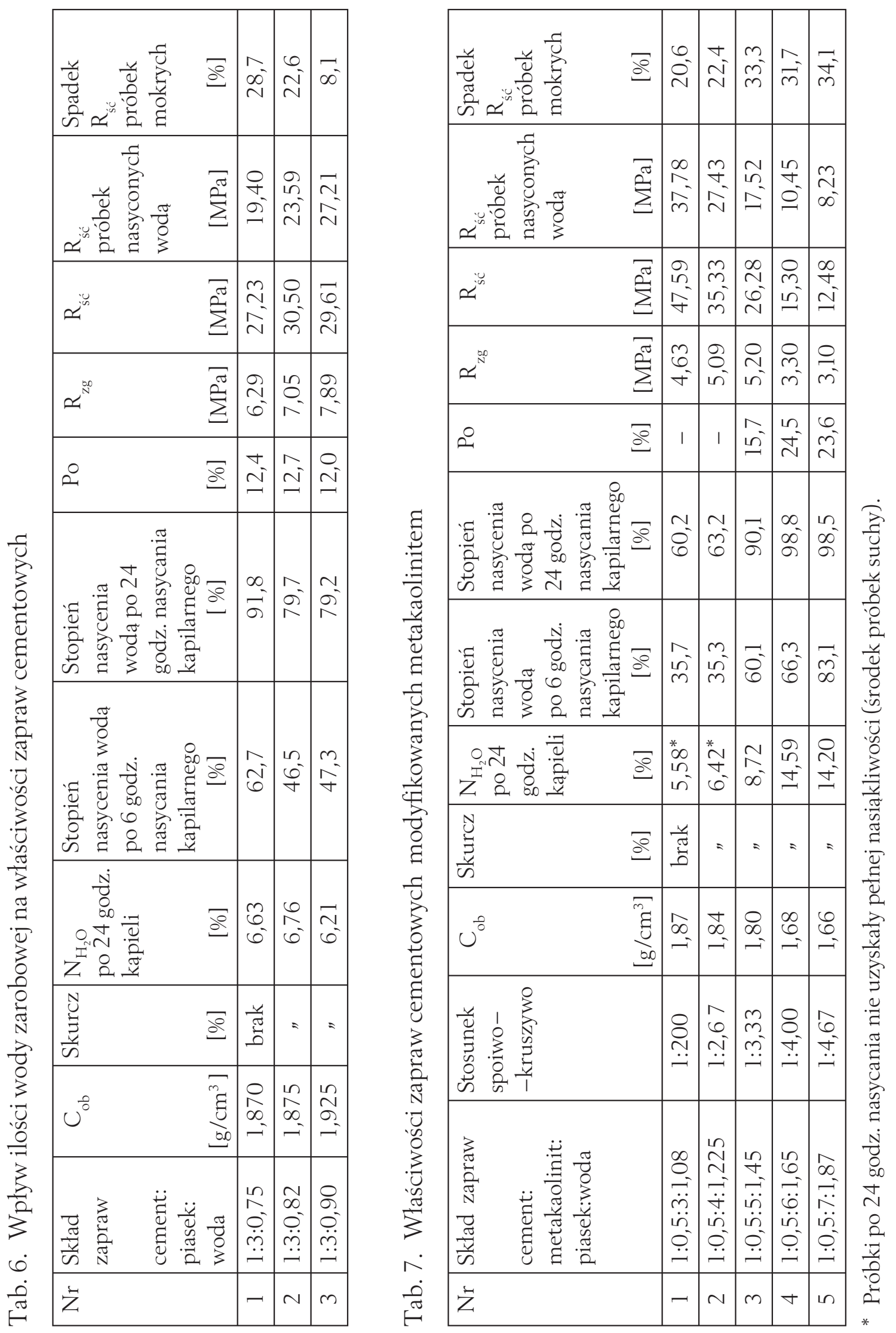

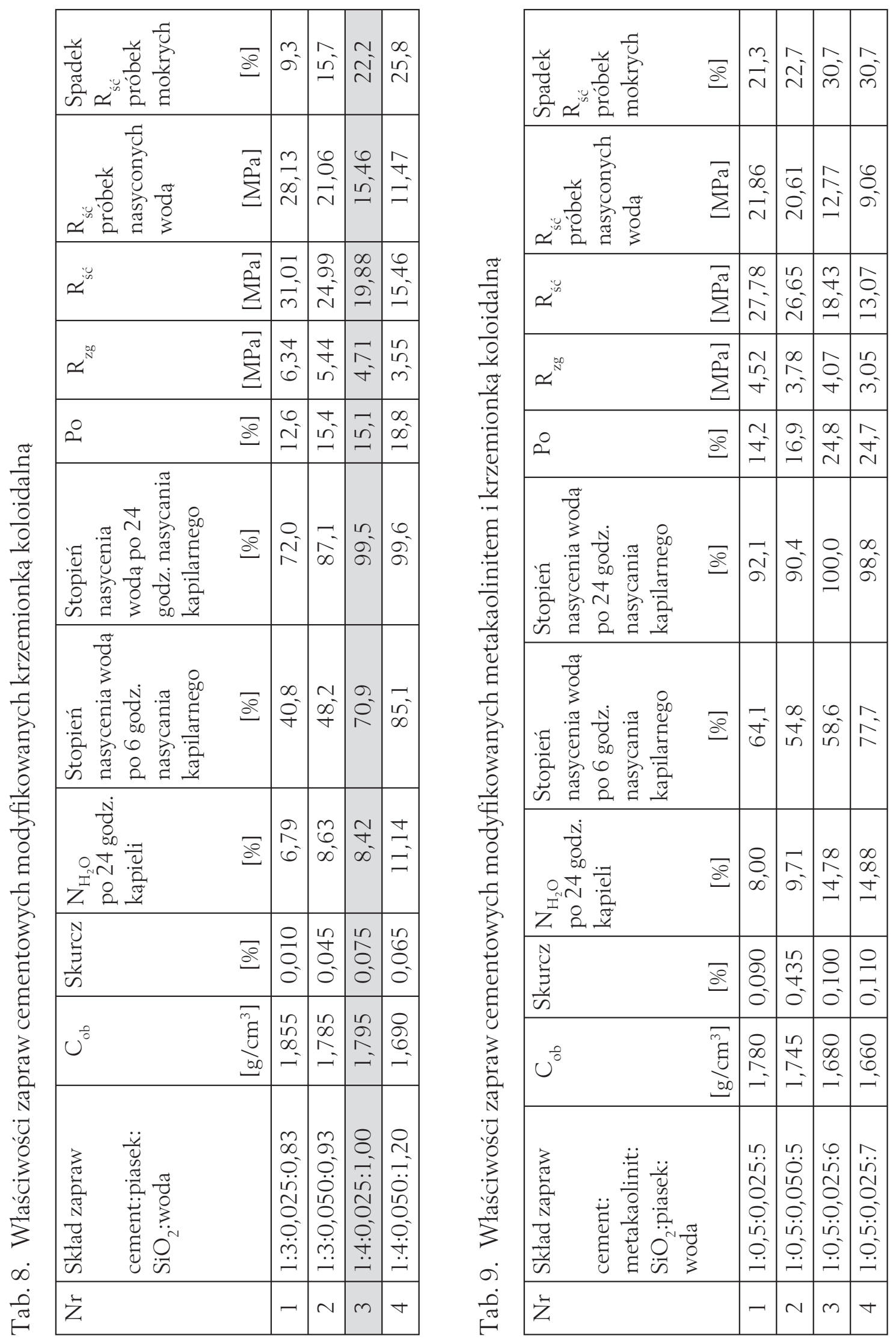
[146]

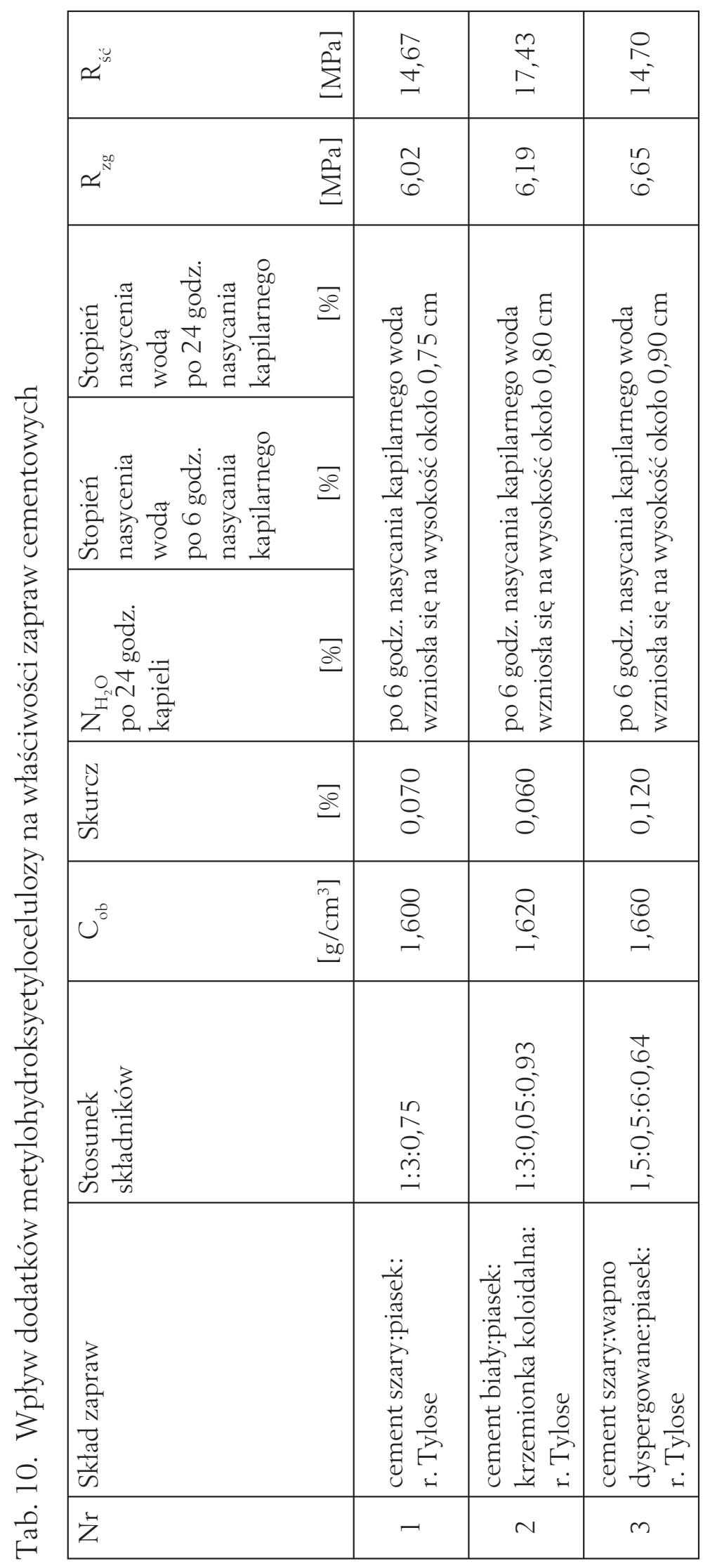



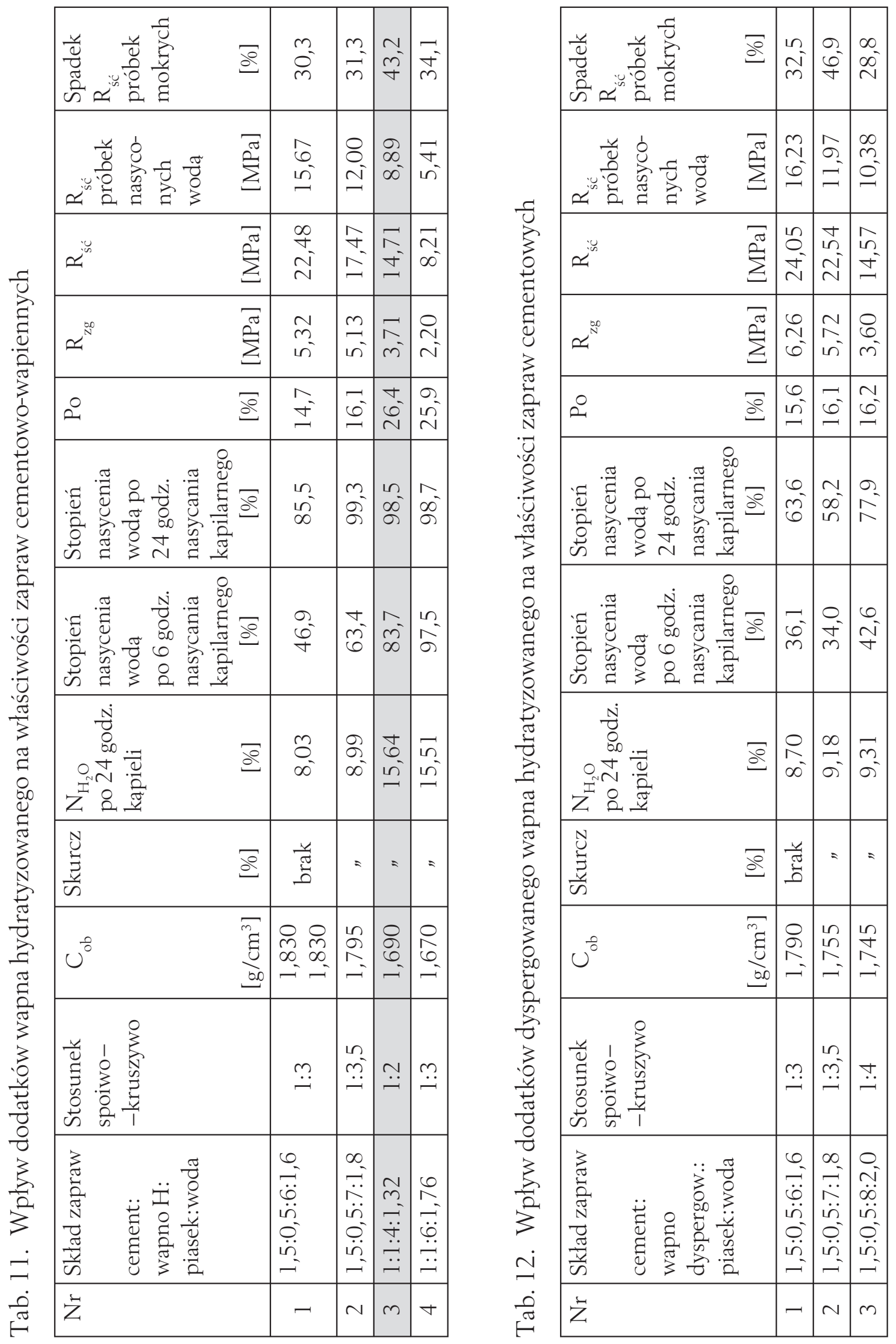


\begin{tabular}{|c|c|c|c|c|c|c|c|c|}
\hline 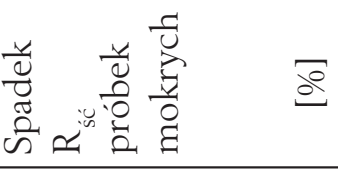 & $\begin{array}{l}\hat{0} \\
\bar{m}\end{array}$ & $\begin{array}{l}\hat{0} \\
\hat{0} \\
n^{2}\end{array}$ & $\begin{array}{l}m \\
\tilde{D}^{\prime}\end{array}$ & $\begin{array}{c}0 \\
0 \\
0 \\
\sim\end{array}$ & $\bar{m}$ & ṽ & $\stackrel{\sim}{\tilde{\sigma}}$ & $\vec{m}$ \\
\hline 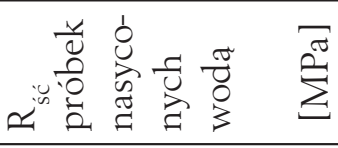 & $\begin{array}{l}n \\
i \\
i\end{array}$ & $\begin{array}{l}0 \\
0 \\
\sigma^{2}\end{array}$ & $\left|\begin{array}{l}0 \\
0 \\
0 \\
-1\end{array}\right|$ & $\begin{array}{l}\tilde{6} \\
\sigma^{2}\end{array}$ & 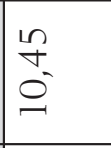 & $\begin{array}{l}0 \\
\stackrel{1}{5} \\
\ln \\
-1\end{array}$ & $\begin{array}{l}\infty \\
\infty \\
\infty\end{array}$ & $\begin{array}{l}F \\
i n\end{array}$ \\
\hline$\sum^{\infty}$ & 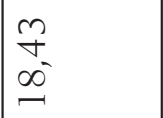 & $\begin{array}{l}0 \\
0 \\
m \\
n\end{array}$ & $\begin{array}{l}1 n \\
N \\
N \\
N\end{array}$ & $\begin{array}{c}n \\
m \\
m\end{array}$ & $\begin{array}{l}0 \\
m \\
\text { in } \\
=\end{array}$ & $\begin{array}{l}\infty \\
\infty \\
\infty \\
= \\
=\end{array}$ & r & $\vec{\sim}$ \\
\hline$\sum^{\pi}$ & $\begin{array}{l}0 \\
0 \\
\forall\end{array}$ & $\begin{array}{l}n \\
0 \\
m \\
m\end{array}$ & $\left|\begin{array}{l}N \\
N \\
\forall\end{array}\right|$ & $\left|\begin{array}{l}\frac{10}{a} \\
m^{\prime}\end{array}\right|$ & $\begin{array}{l}0 \\
m \\
m \\
m\end{array}$ & $\vec{r}$ & $\bar{n}$ & 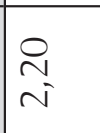 \\
\hline 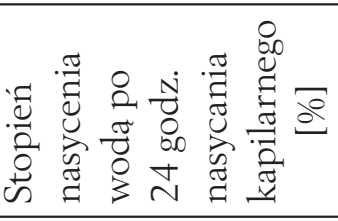 & 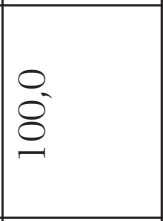 & $\begin{array}{l}\infty \\
\infty \\
\infty^{-}\end{array}$ & $\left|\begin{array}{l}0 \\
0 \\
0 \\
0\end{array}\right|$ & $\begin{array}{l}0 \\
8 \\
0\end{array}$ & $\begin{array}{l}\infty \\
\infty \\
\infty \\
\infty\end{array}$ & $\begin{array}{l}10 \\
8 \\
8\end{array}$ & $\begin{array}{l}n \\
\infty \\
\infty \\
\infty\end{array}$ & $\begin{array}{l}1 \\
\infty^{-} \\
\sigma^{2}\end{array}$ \\
\hline 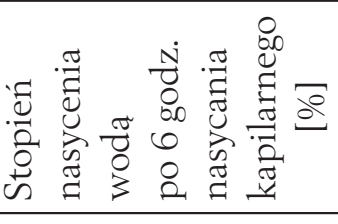 & $\begin{array}{l}0 \\
\infty 0^{-} \\
\text {in }\end{array}$ & $\hat{N}$ & $\overrightarrow{\mathrm{j}}$ & $\left|\begin{array}{l}n \\
\hat{n} \\
\sigma\end{array}\right|$ & $\begin{array}{l}3 \\
6 \\
6\end{array}$ & $\begin{array}{l}0 \\
0 \\
0 \\
1\end{array}$ & $\begin{array}{l}\hat{n} \\
m^{\prime}\end{array}$ & $\begin{array}{l}n \\
\hat{n}\end{array}$ \\
\hline 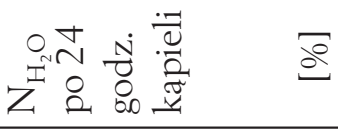 & $\begin{array}{l}\infty \\
N \\
\pm \\
-\end{array}$ & $\begin{array}{l}\infty \\
\infty \\
\pm \\
\pm\end{array}$ & $\left|\begin{array}{l}1 n \\
1 n \\
\infty\end{array}\right|$ & $\begin{array}{l}0 \\
0 \\
0 \\
0\end{array}$ & $\begin{array}{l}0 \\
i n \\
\pm \\
I\end{array}$ & $\begin{array}{l}\stackrel{v}{\checkmark} \\
\infty\end{array}$ & $\begin{array}{l}5 \\
6 \\
10 \\
-1\end{array}$ & $\begin{array}{l}\ln \\
\operatorname{in} \\
-1\end{array}$ \\
\hline 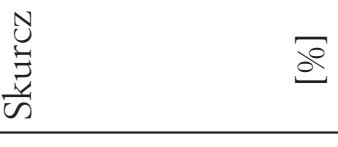 & $\begin{array}{l}8 \\
8 \\
0\end{array}$ & $\stackrel{0}{a}$ & $\mid \begin{array}{l}x \\
\tilde{\sigma} \\
0\end{array}$ & $=$ & $=$ & $\begin{array}{l}10 \\
0 \\
0 \\
0\end{array}$ & है & $=$ \\
\hline 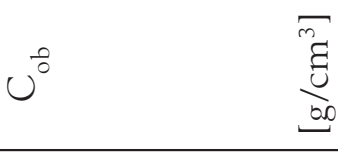 & {$\left[\begin{array}{l}\infty \\
0 \\
-\end{array}\right.$} & $\begin{array}{l}0 \\
0 \\
-1\end{array}$ & $\begin{array}{l}\tilde{N} \\
\infty \\
-1\end{array}$ & $\stackrel{m}{n}=$ & $\begin{array}{l}\infty \\
0 \\
- \\
-\end{array}$ & $\stackrel{0}{\Omega}$ & $\begin{array}{l}8 \\
6 \\
-1\end{array}$ & $\hat{0}$ \\
\hline $\begin{array}{l}\cdot \frac{0}{0} \\
\frac{0}{0} \\
\frac{0}{0} \\
0 \\
0\end{array}$ & 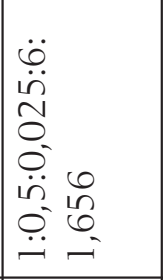 & 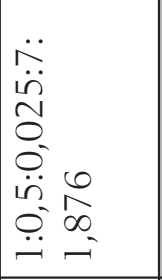 & \begin{tabular}{|c|}
0 \\
$\circ$ \\
0 \\
$\dot{+}$ \\
$\stackrel{-}{-}$ \\
\end{tabular} & $\mid$\begin{tabular}{c}
0 \\
$\sim$ \\
\hdashline$-\tilde{n}$ \\
$\stackrel{n}{-}$ \\
\end{tabular} & 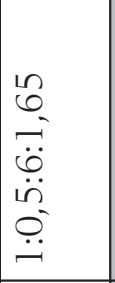 & $\mid$\begin{tabular}{l}
8 \\
8 \\
\hdashline$\ddot{n}$ \\
$\tilde{n}$ \\
0 \\
0 \\
$\dot{+}$ \\
$\stackrel{-}{-}$
\end{tabular} & $\begin{array}{l}\stackrel{N}{m} \\
\ddot{\sim} \\
\ddot{+} \\
\ddot{\sim}\end{array}$ & $\mid$\begin{tabular}{l}
$\infty$ \\
0 \\
\hdashline \\
$\ddot{\varphi}$ \\
$\dot{\ddot{n}}$ \\
$\ddot{\sim}$
\end{tabular} \\
\hline $\begin{array}{l}3 \\
\frac{\pi}{\pi} \\
\frac{\pi}{\pi} \\
\text { D } \\
\frac{\pi}{i} \\
\frac{i}{n} \\
\end{array}$ & 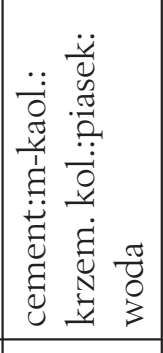 & 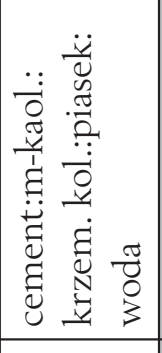 & 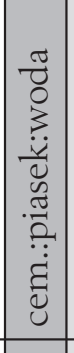 & 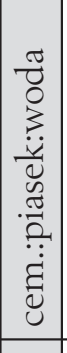 & 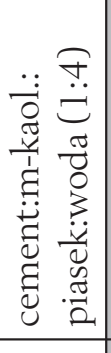 & 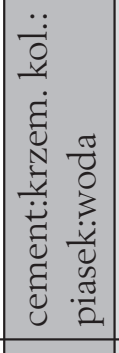 & 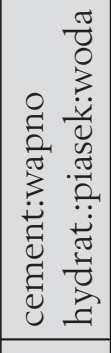 & 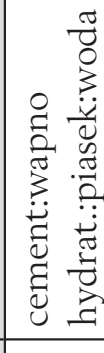 \\
\hline$\vec{z}$ & - & $\sim$ & $m$ & $\nabla$ & in & 6 & $n$ & $\infty$ \\
\hline
\end{tabular}



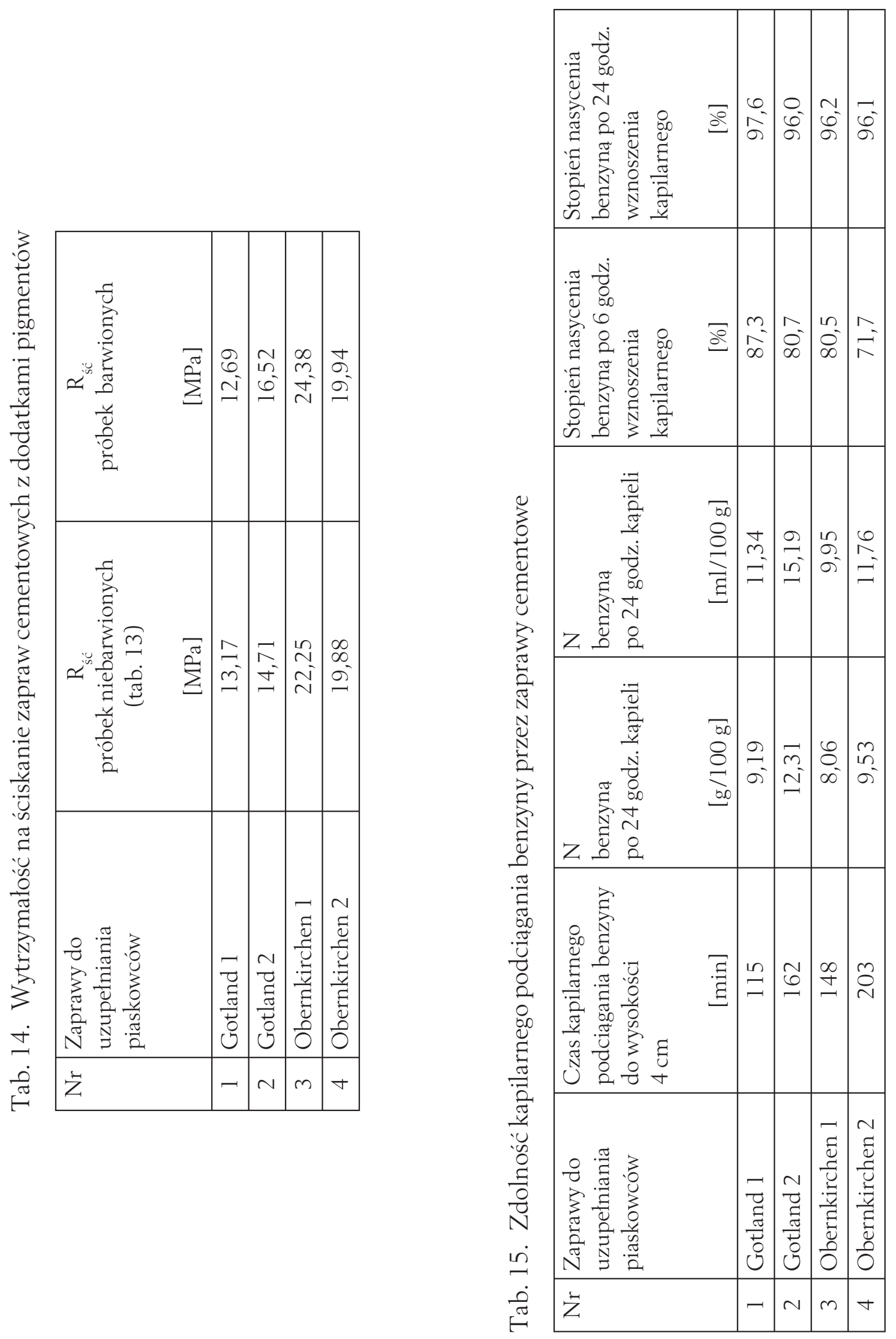


\begin{tabular}{|c|c|c|c|c|c|}
\hline 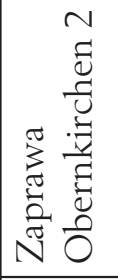 & \multirow{6}{*}{ 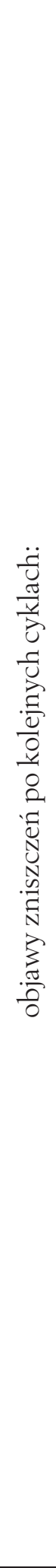 } & 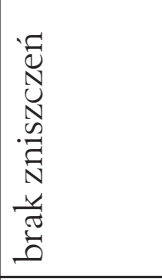 & $=$ & 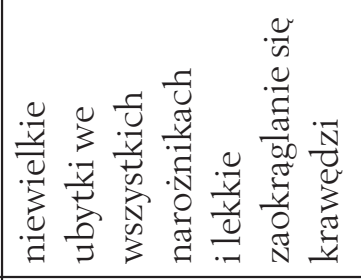 & 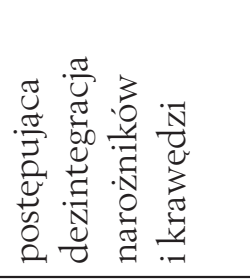 \\
\hline 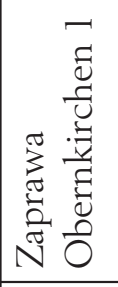 & & 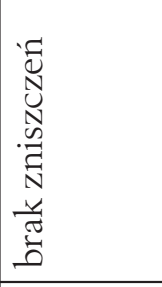 & $=$ & 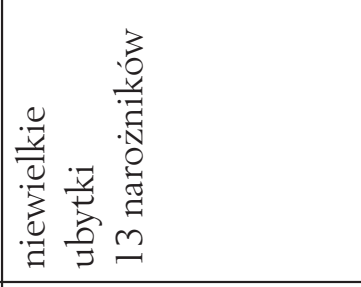 & 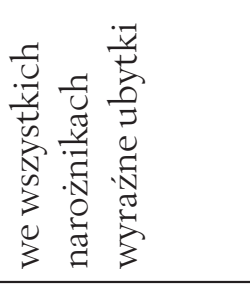 \\
\hline 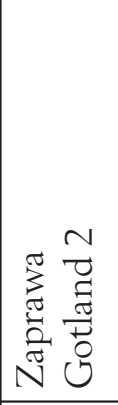 & & 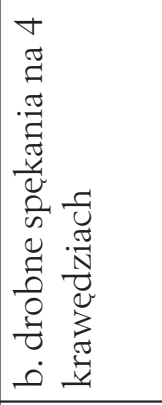 & 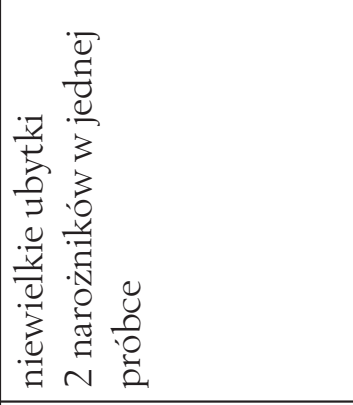 & 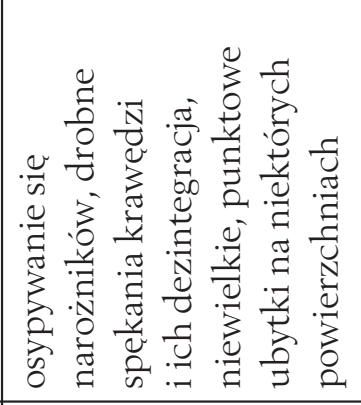 & 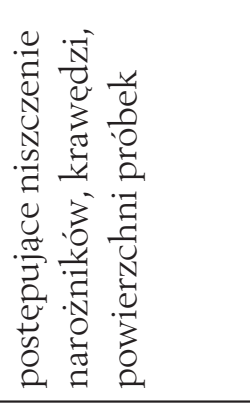 \\
\hline 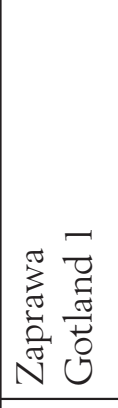 & & 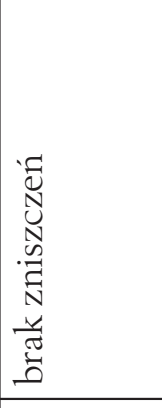 & 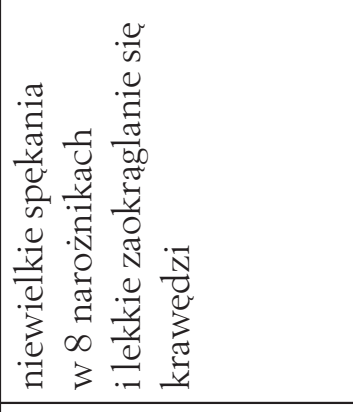 & 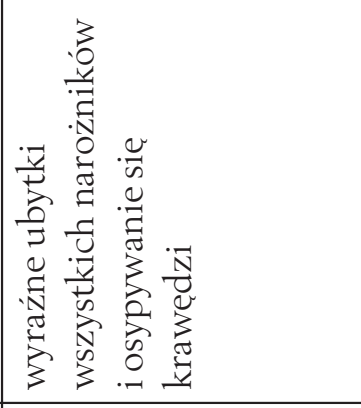 & 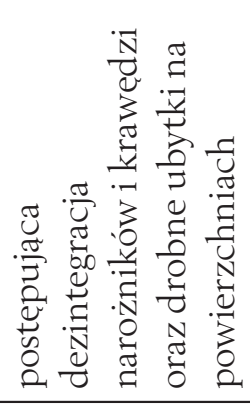 \\
\hline 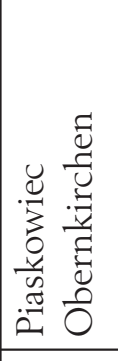 & & 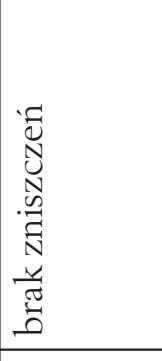 & $=$ & $=$ & 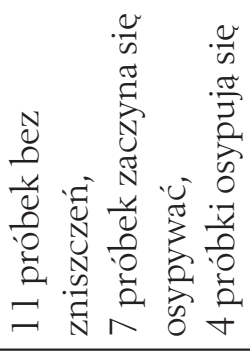 \\
\hline 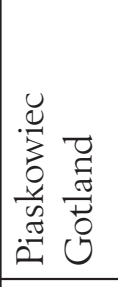 & & 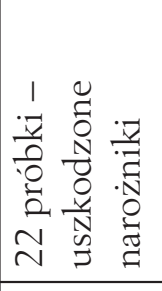 & 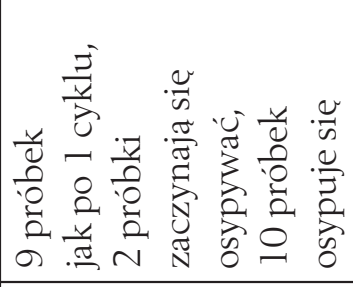 & 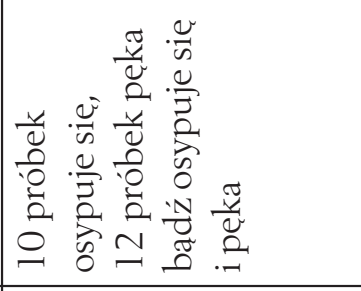 & 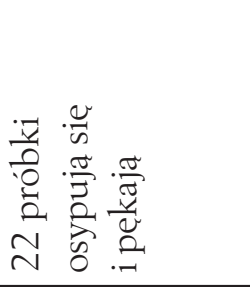 \\
\hline 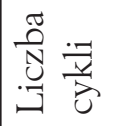 & & - & $\sim$ & $m$ & $\nabla$ \\
\hline
\end{tabular}




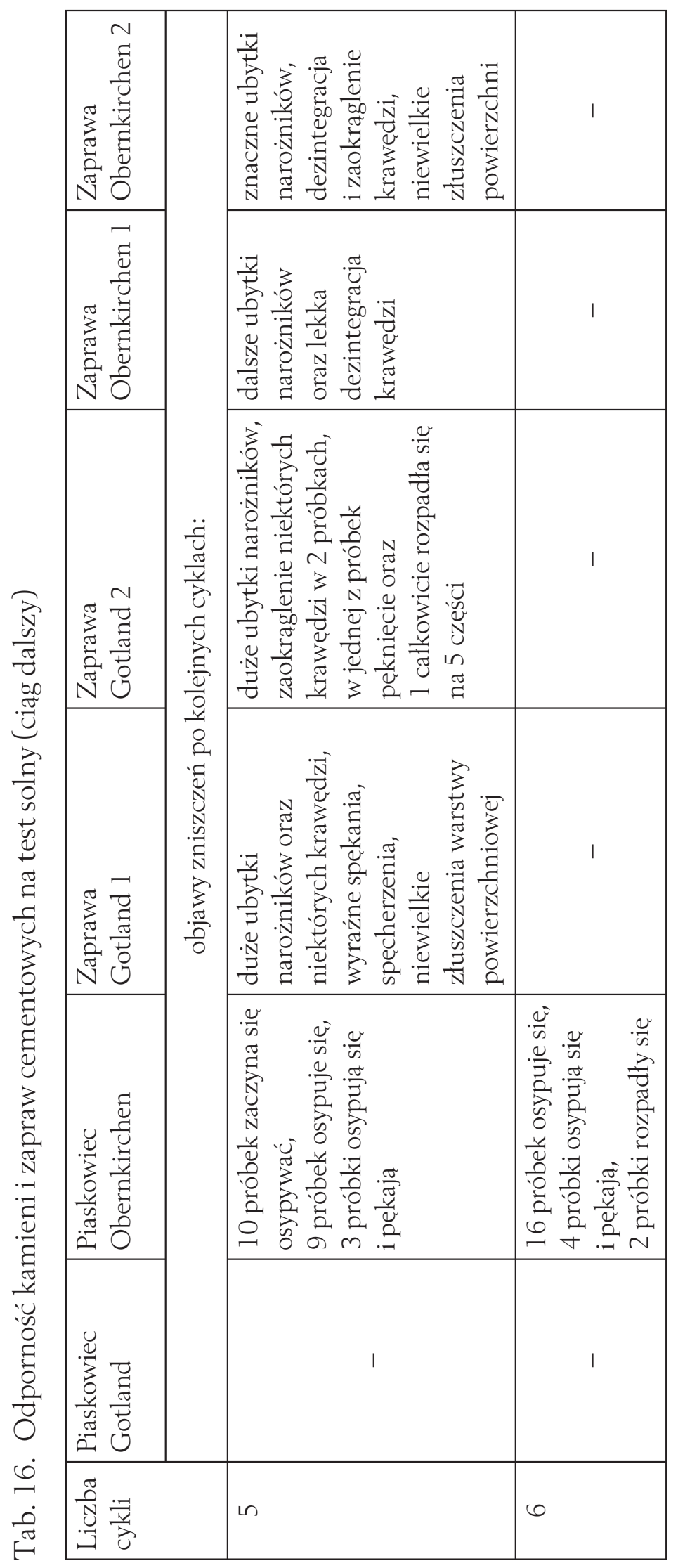



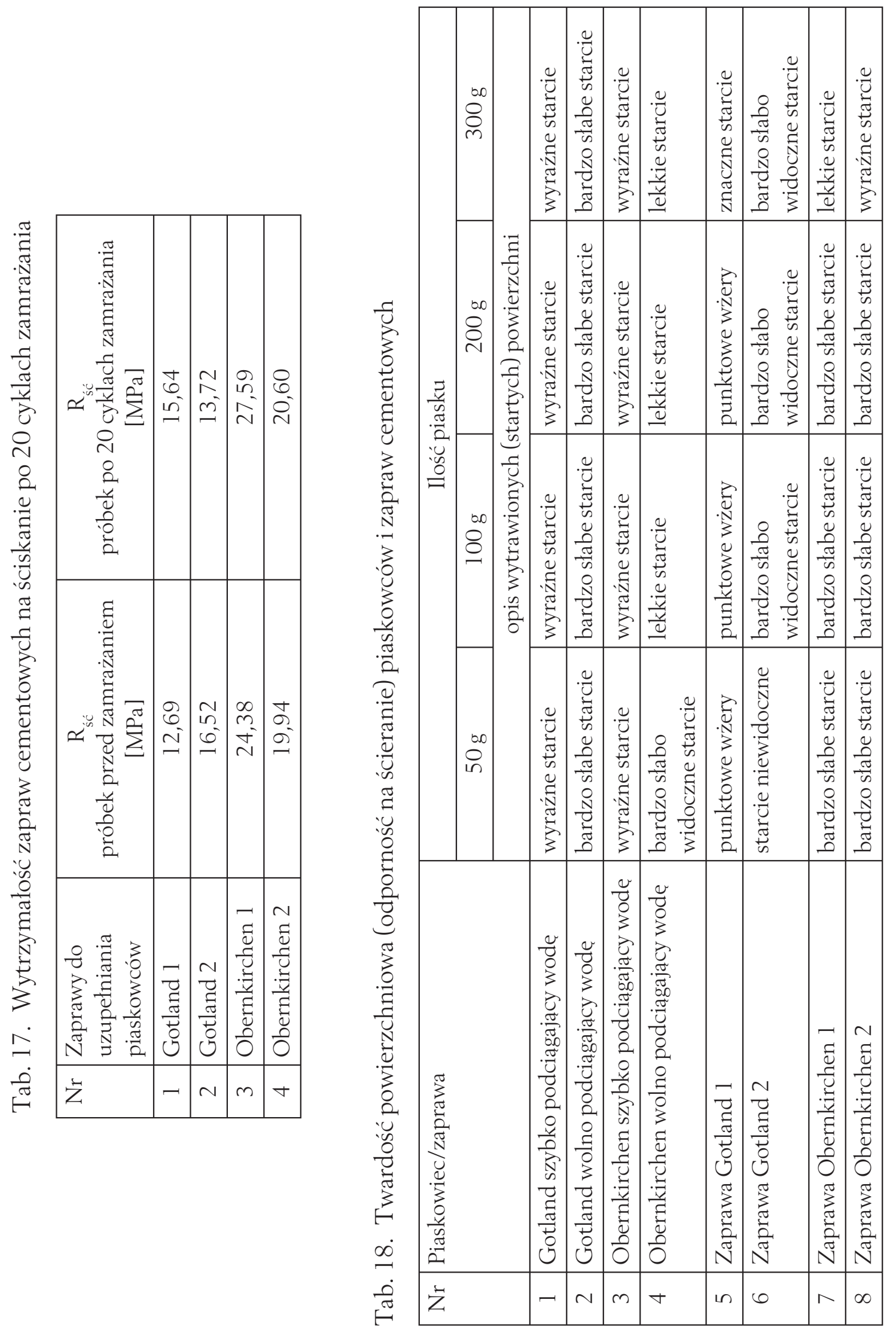

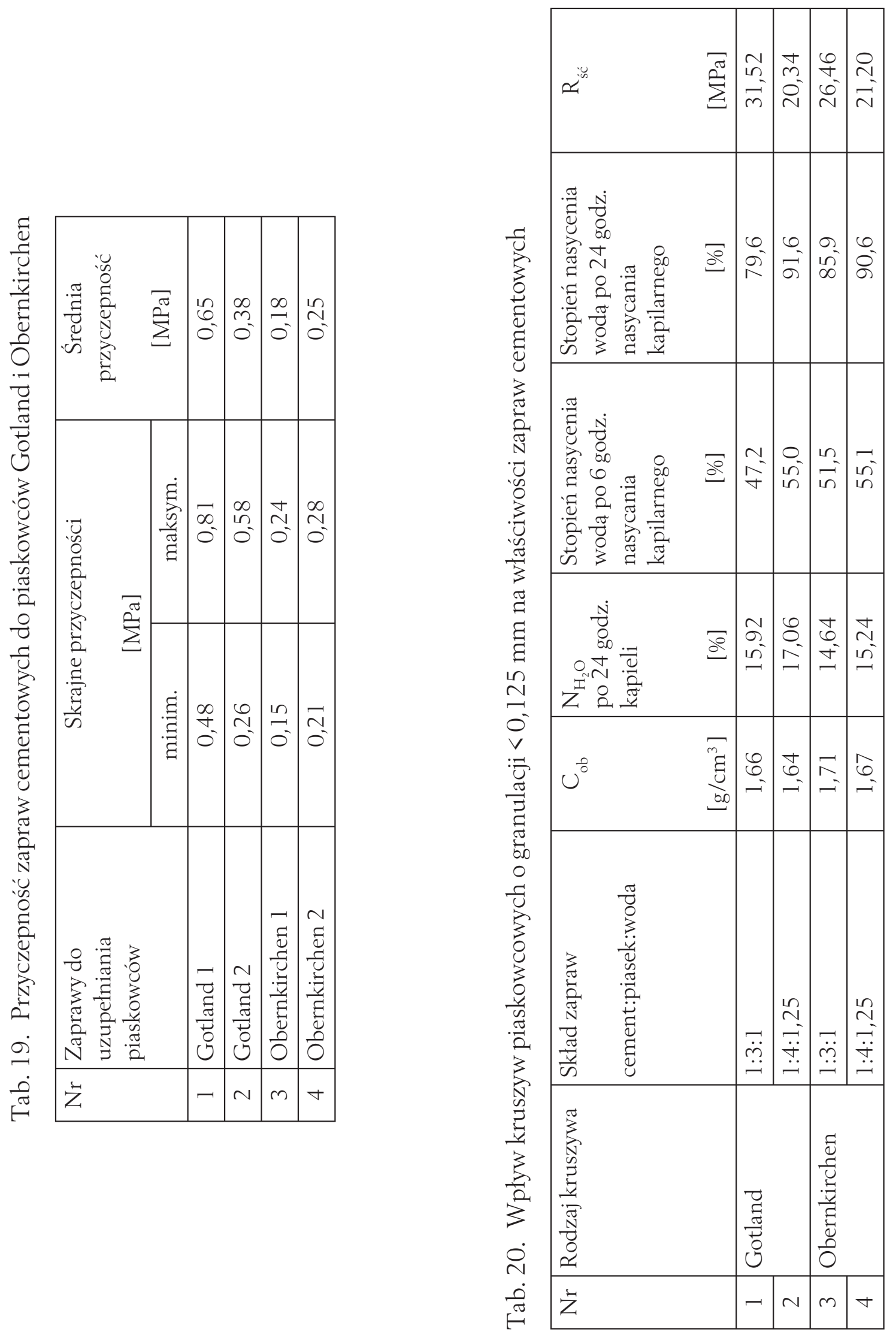


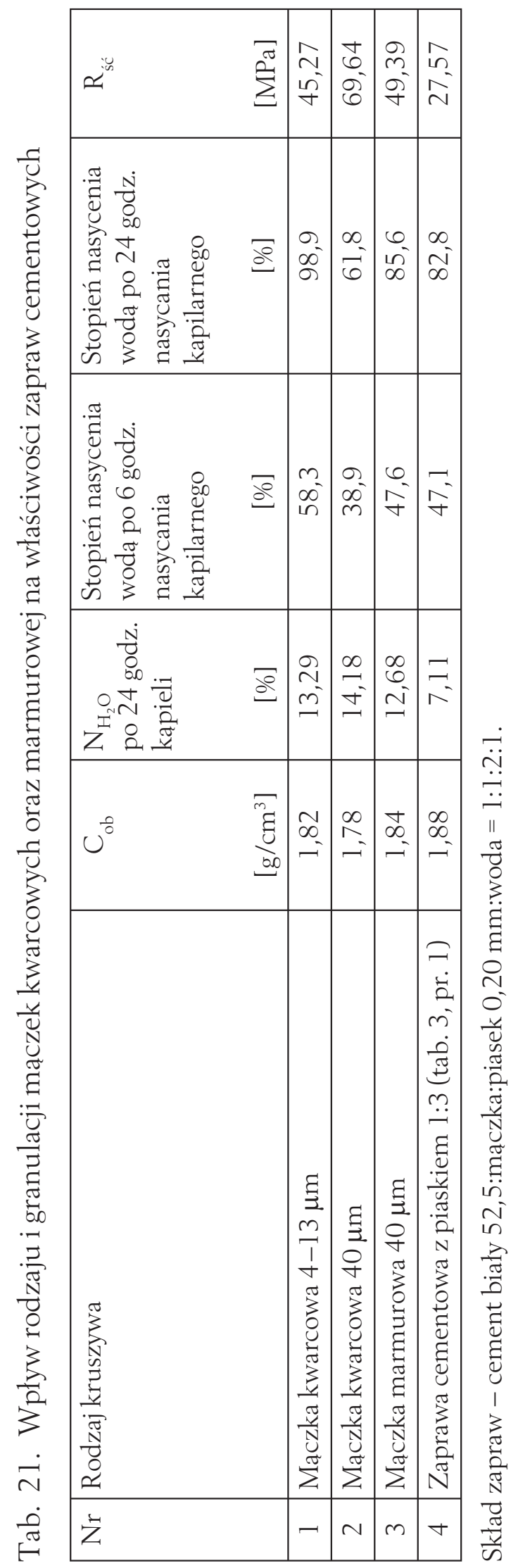




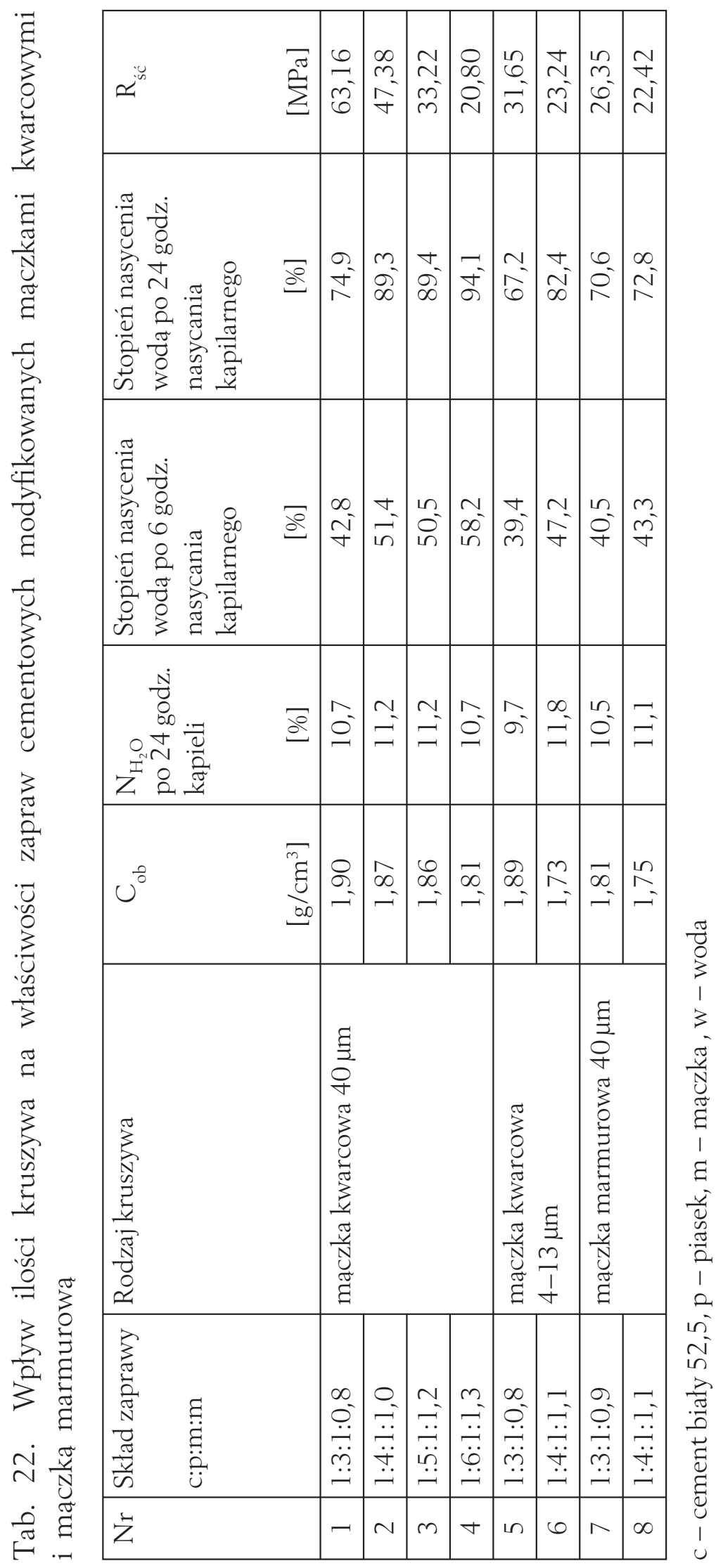




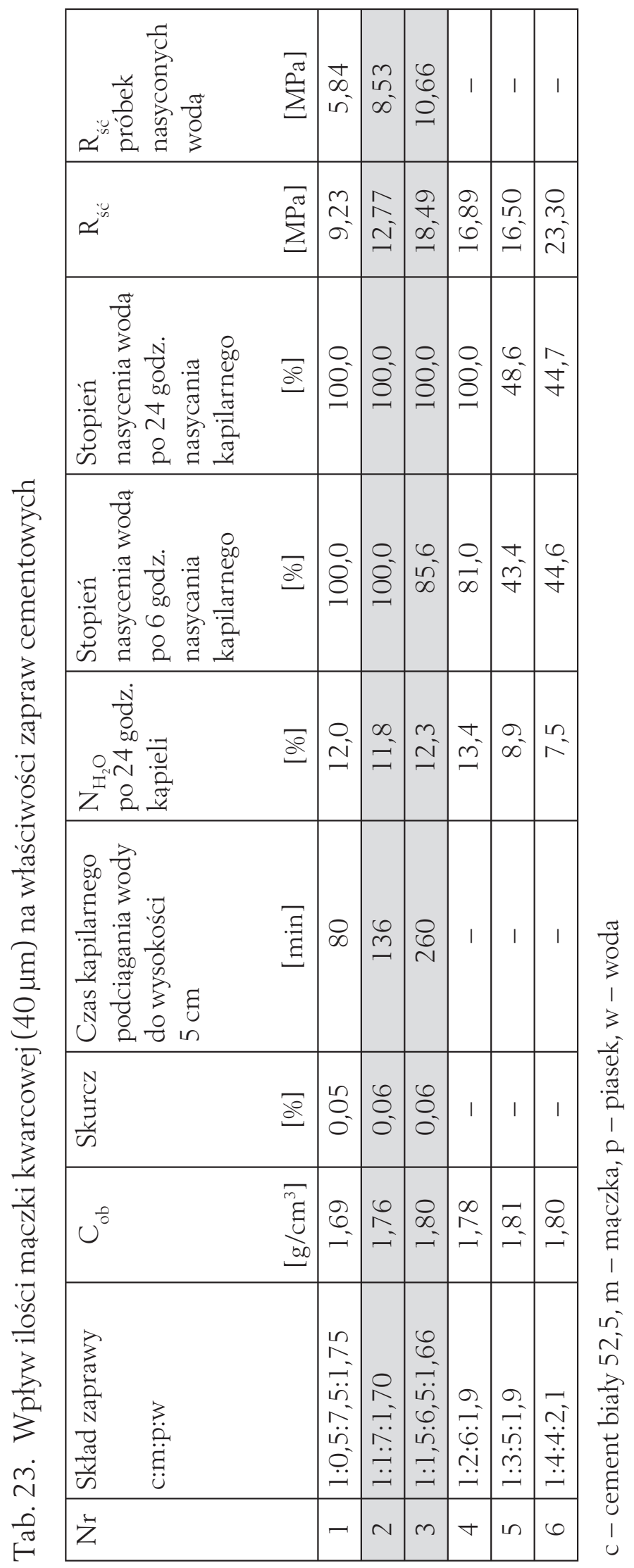


[157]

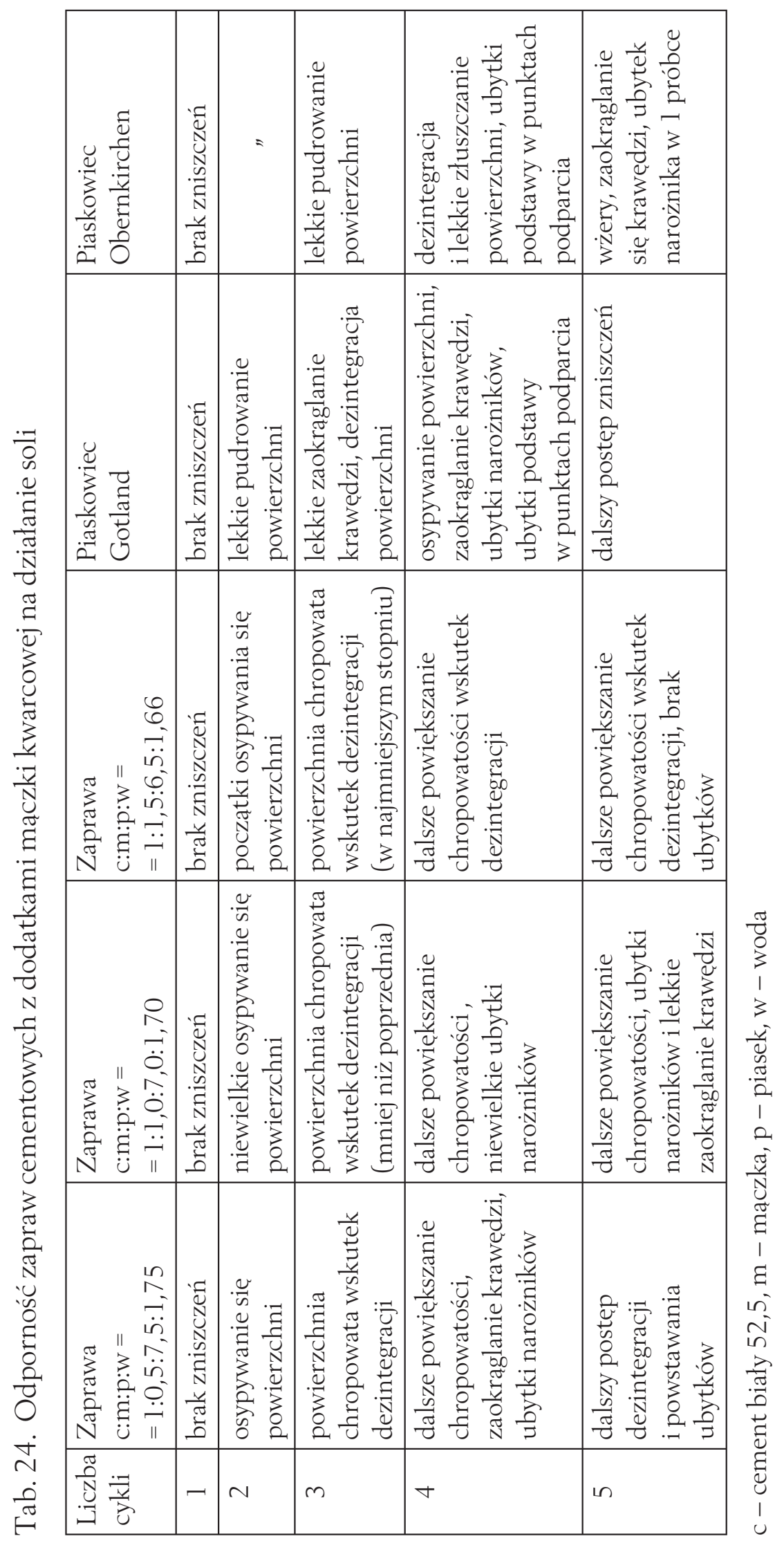



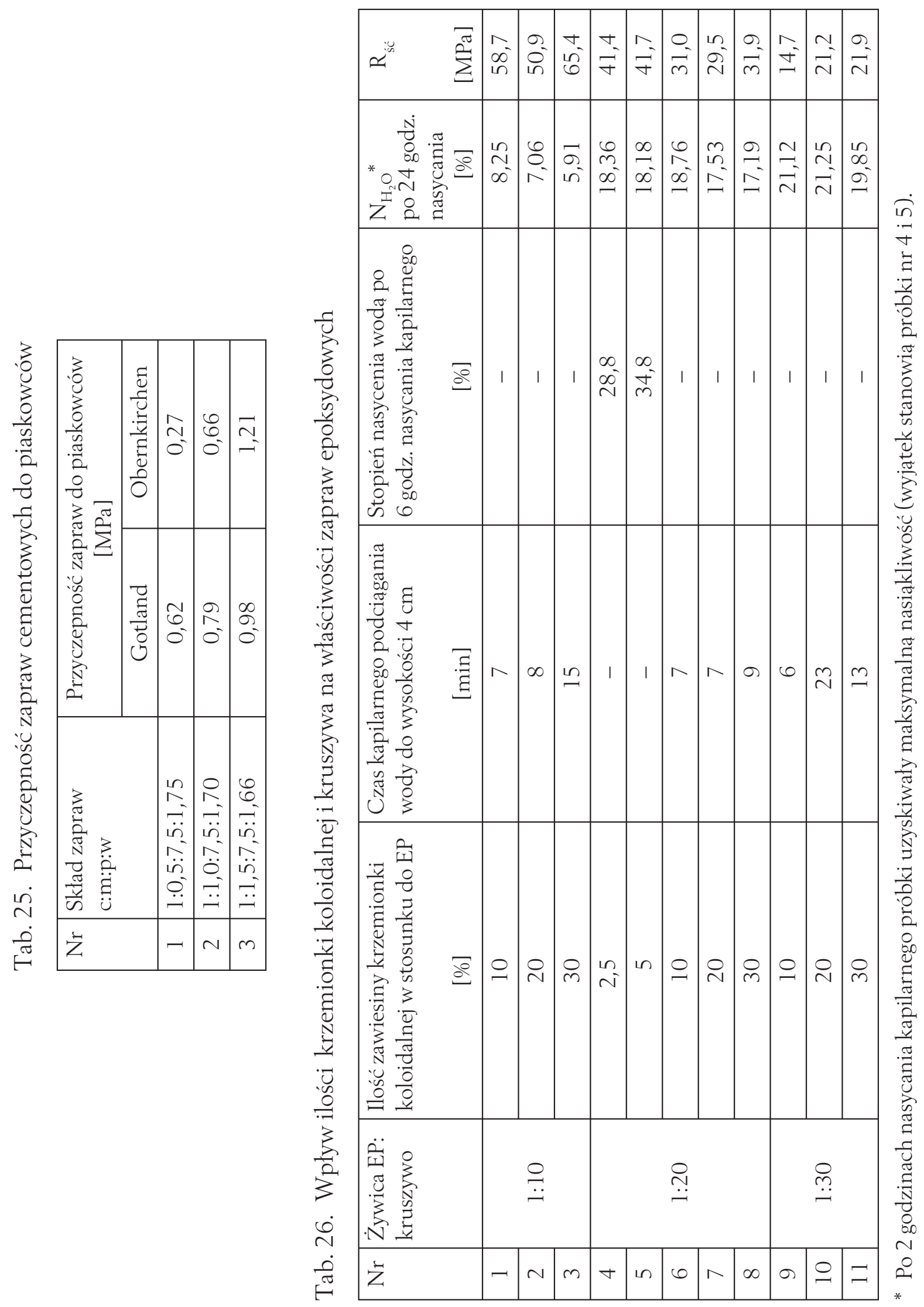

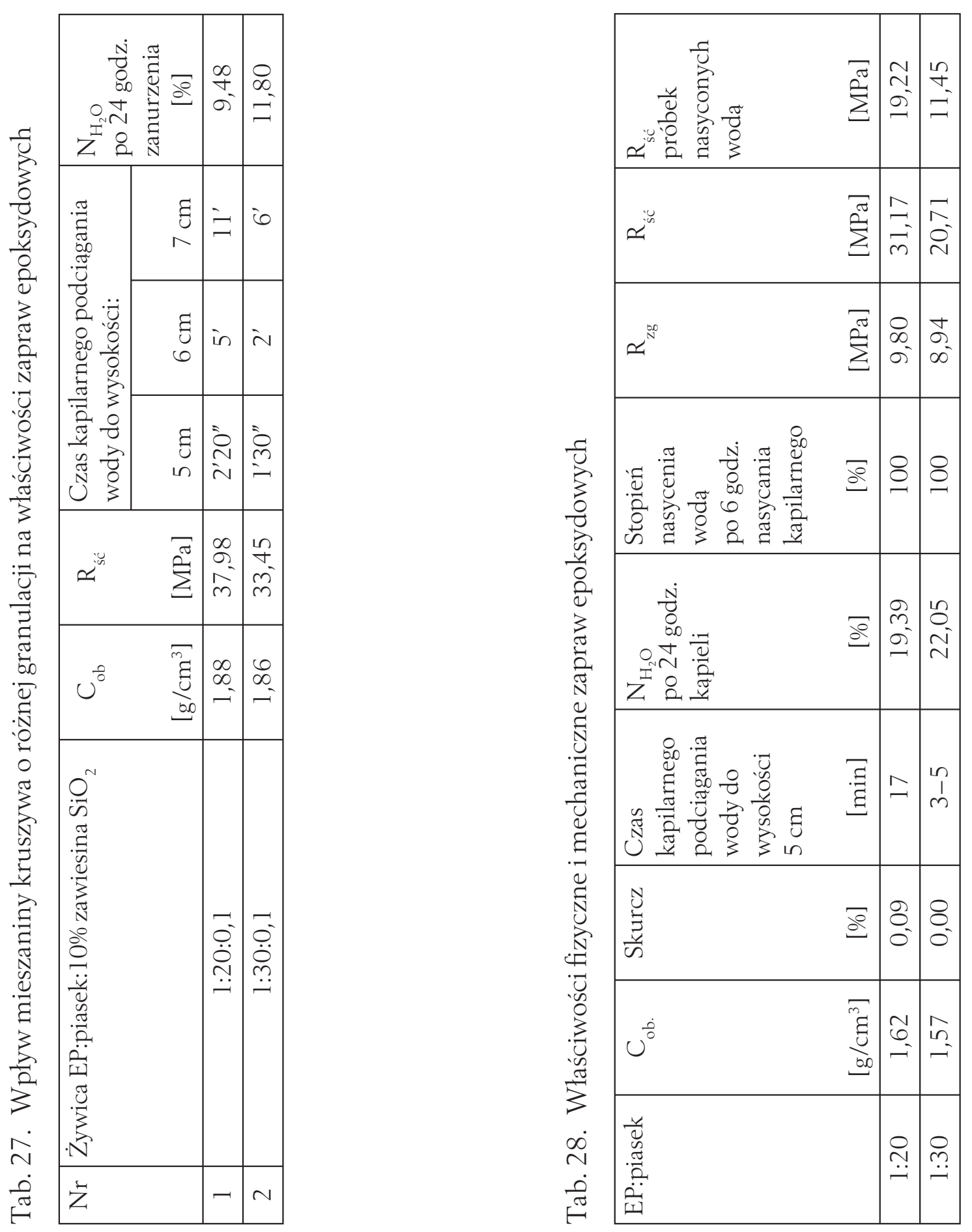
[160]

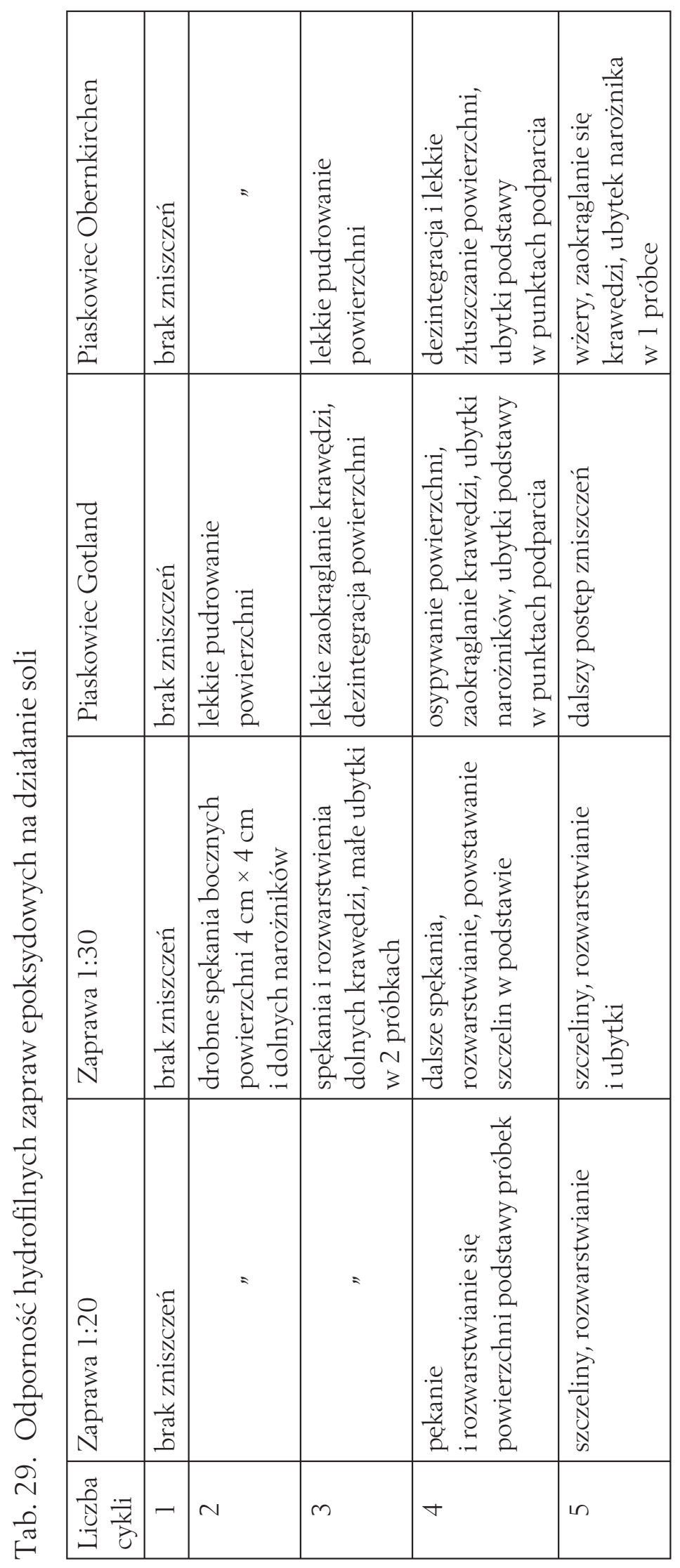



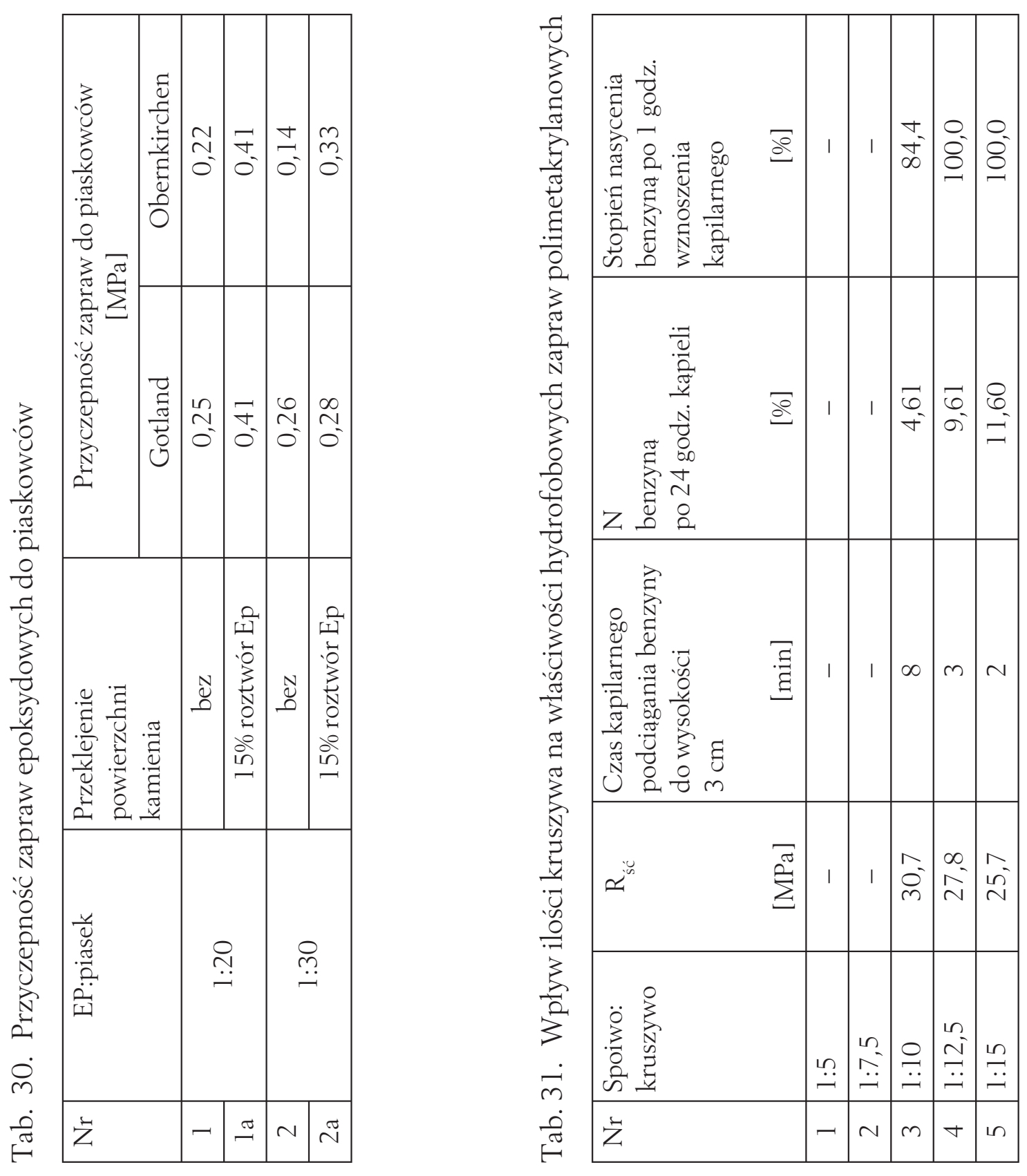


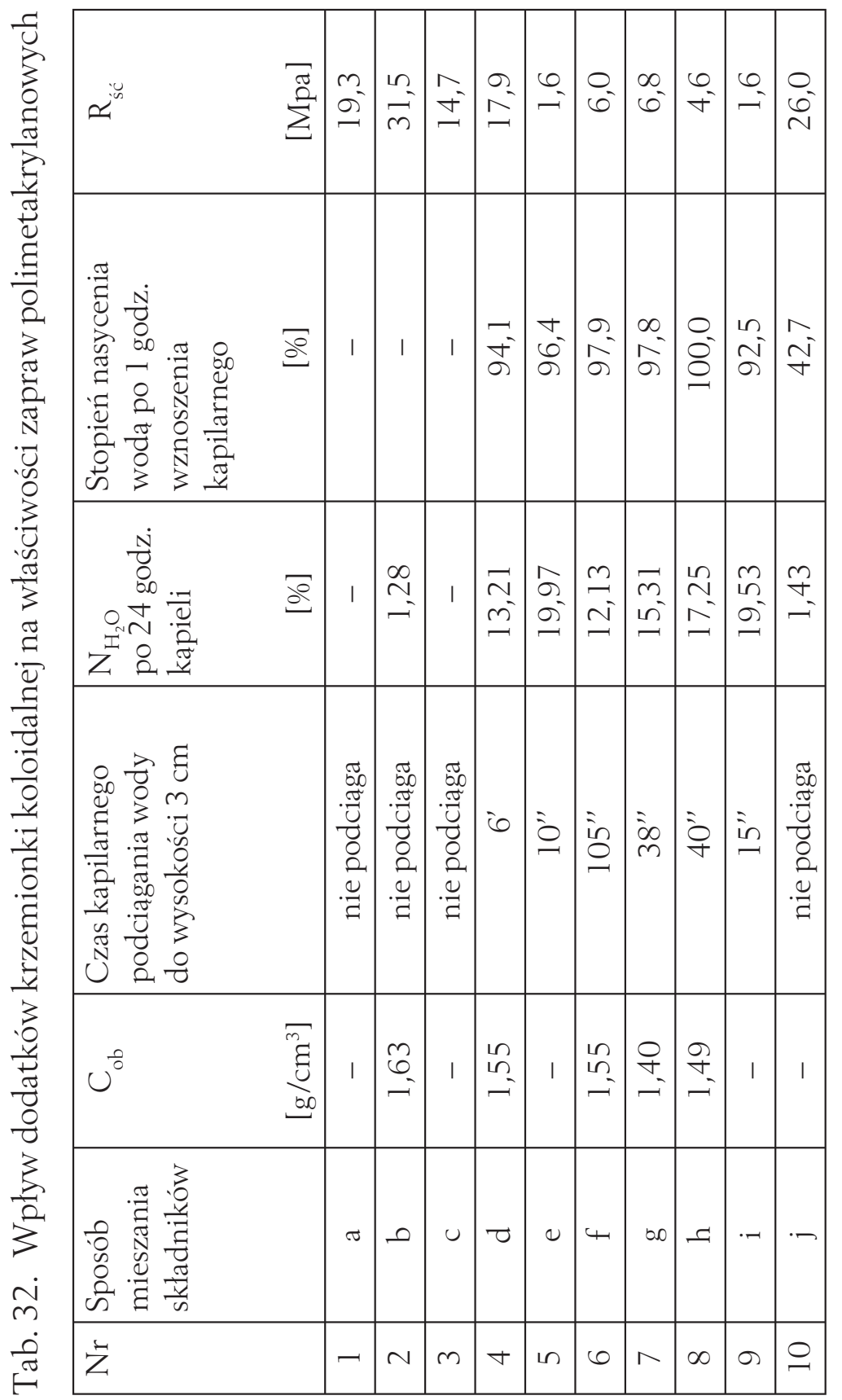



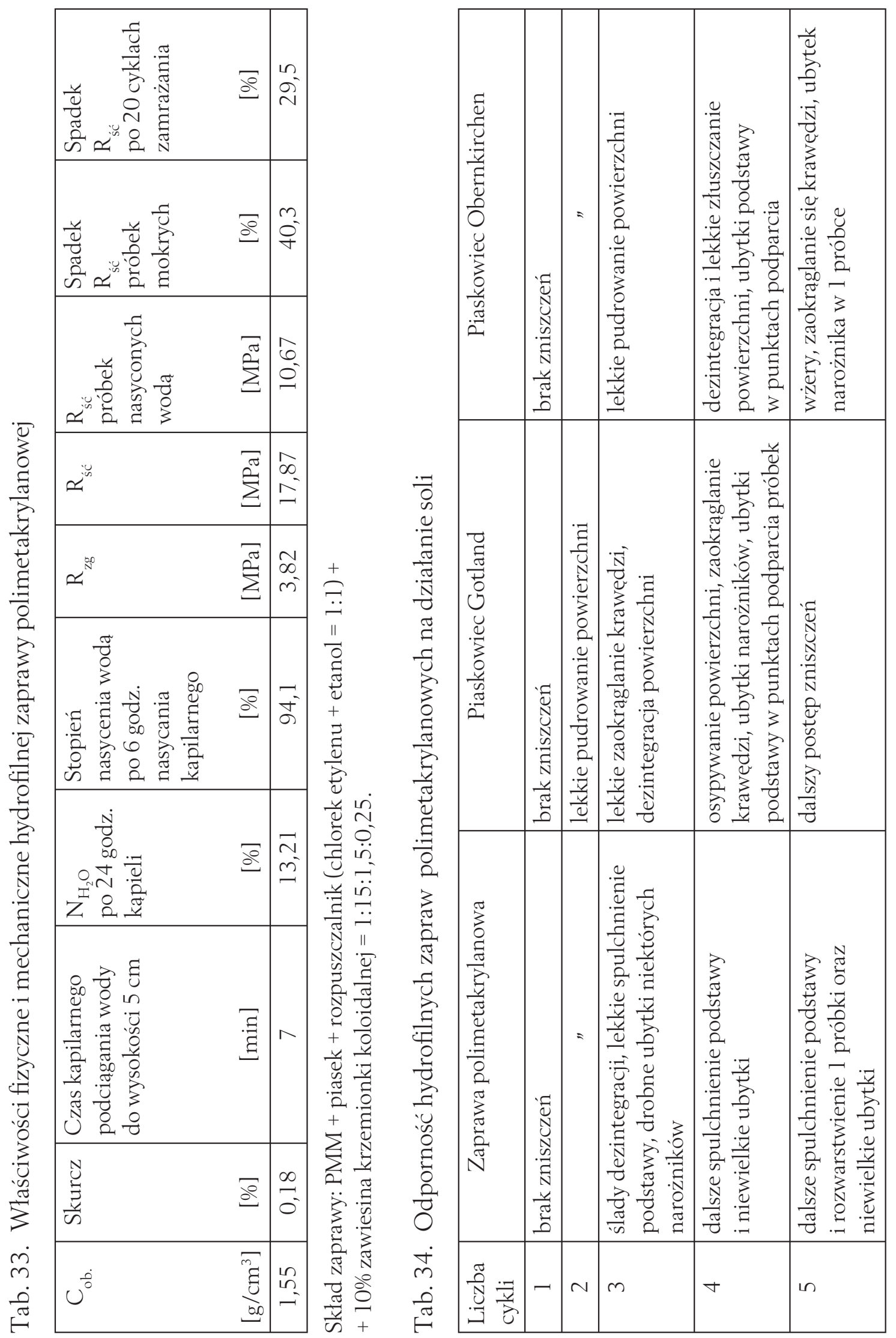
[164]

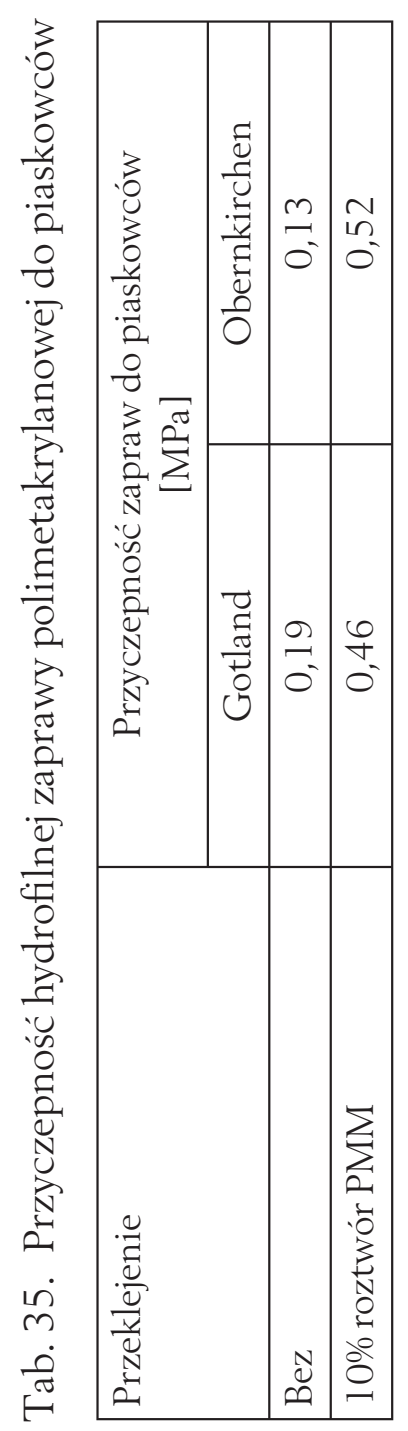




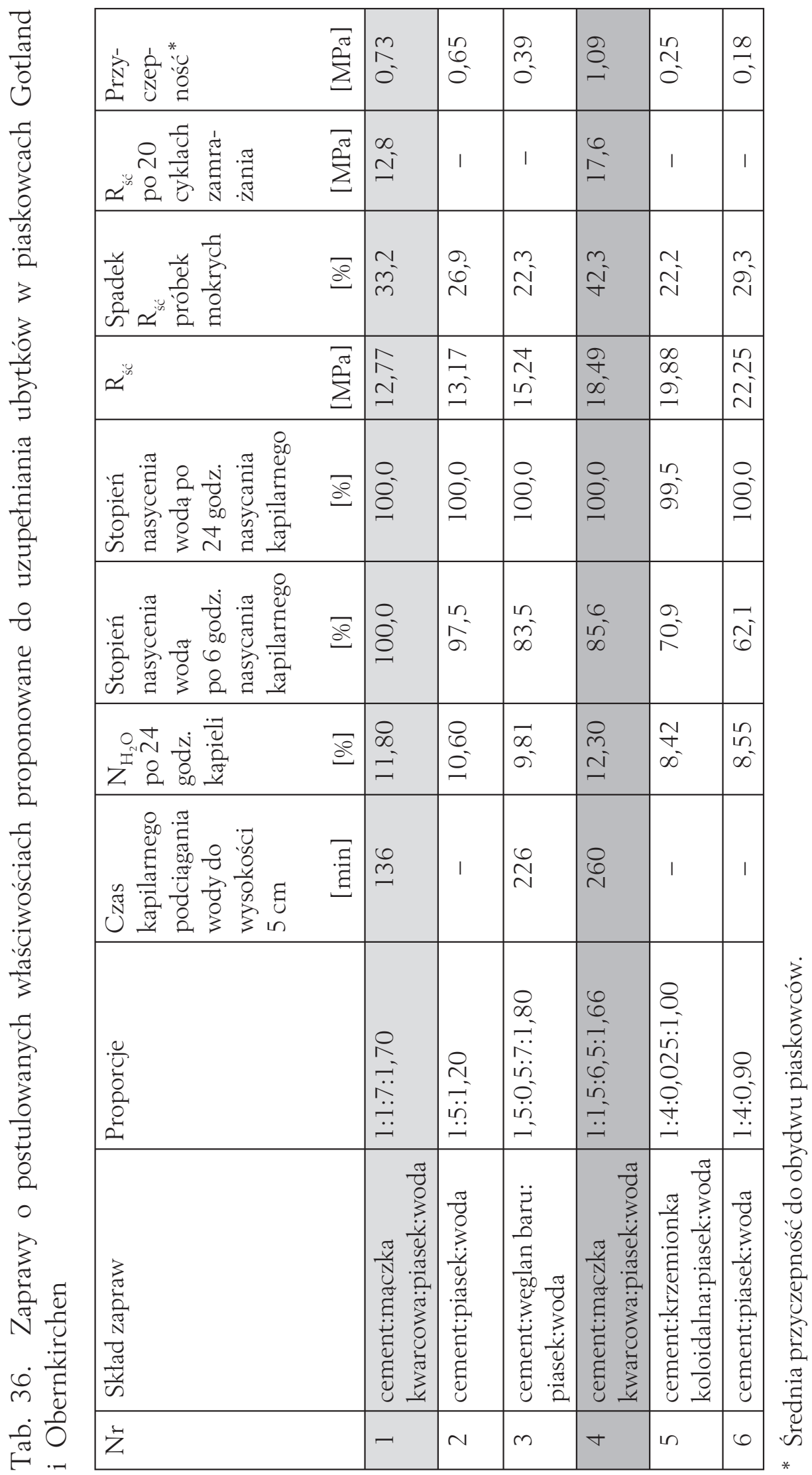



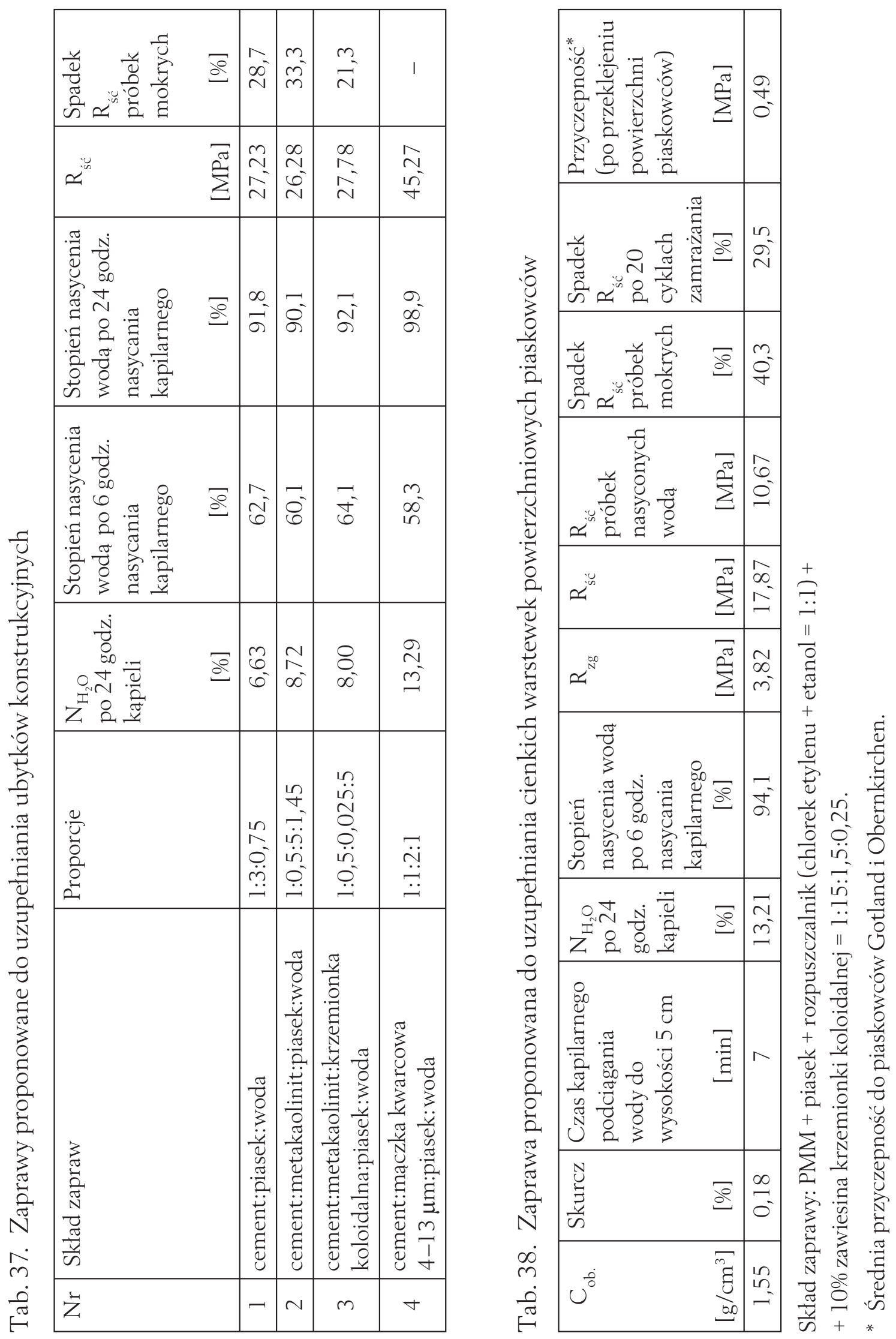


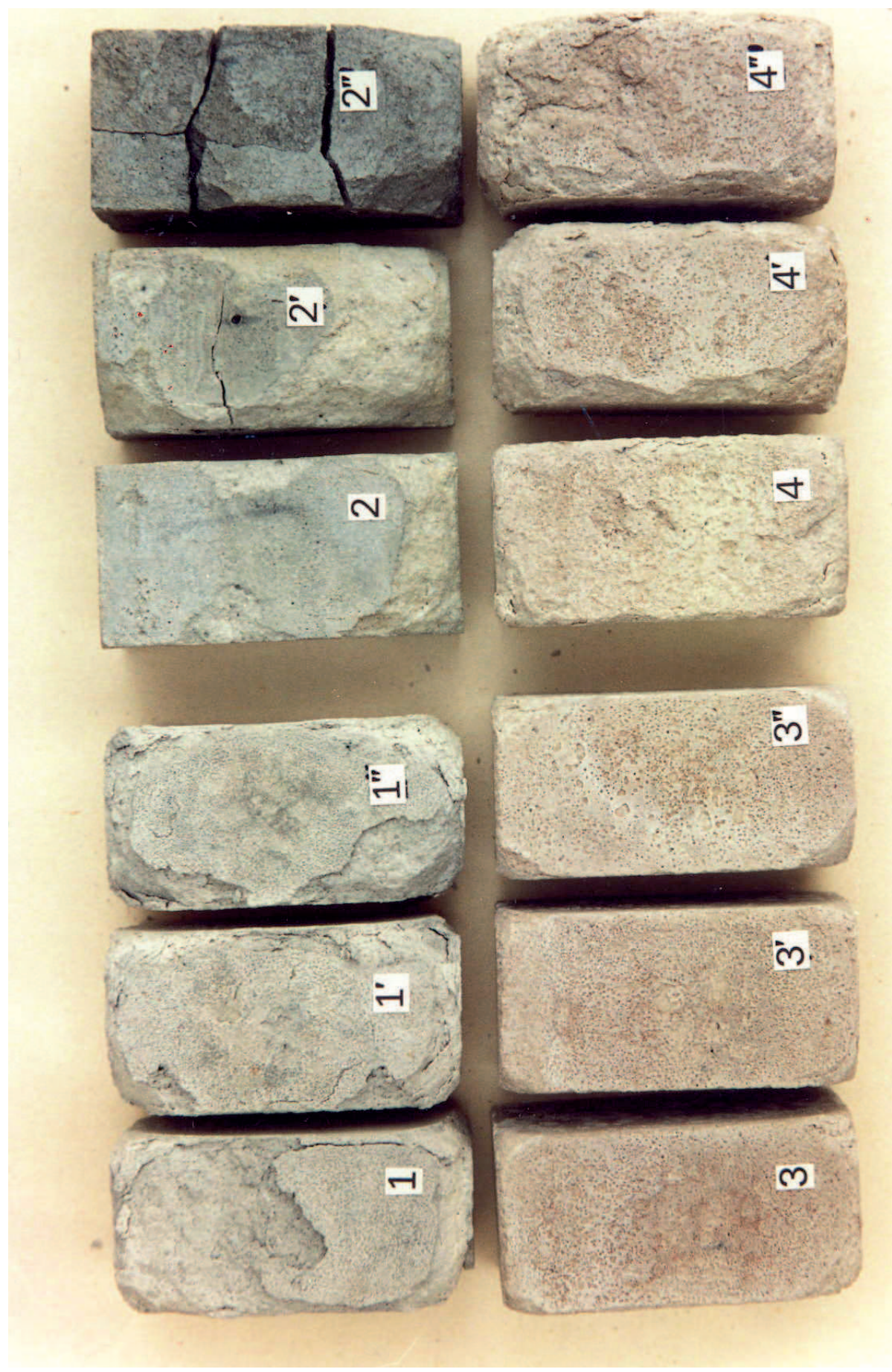

Il. 1. Test solny. Zaprawy cementowe imitujące piaskowce po 5 cyklach (autor wszystkich fot. M. Głowacki):

1 - Gotland 1

2 - Gotland 2

3 - Obernkirchen 1

4 - Obernkirchen 2 


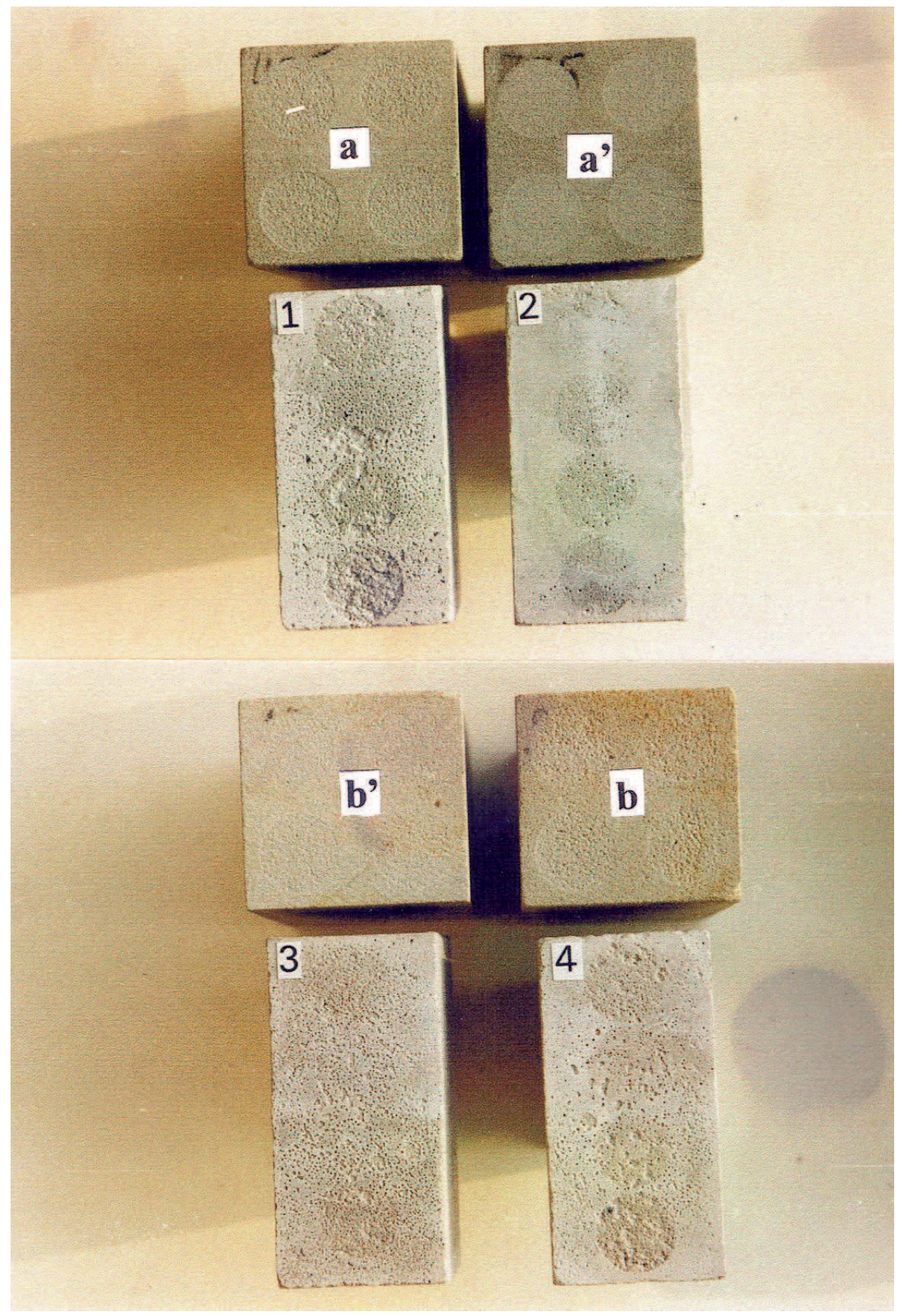

Il. 2. Odporność na ścieranie zapraw cementowych imitujących piaskowce:

1 - Gotland 1

2 - Gotland 2

3 - Obernkirchen 1

4 - Obernkirchen 2

a - piaskowiec Gotland szybko podciagający wode

a' - piaskowiec Gotland wolniej podciągający wode

b - piaskowiec Obernkirchen szybko podciągający wodę

b' - piaskowiec Obernkirchen wolniej podciagający wodę 


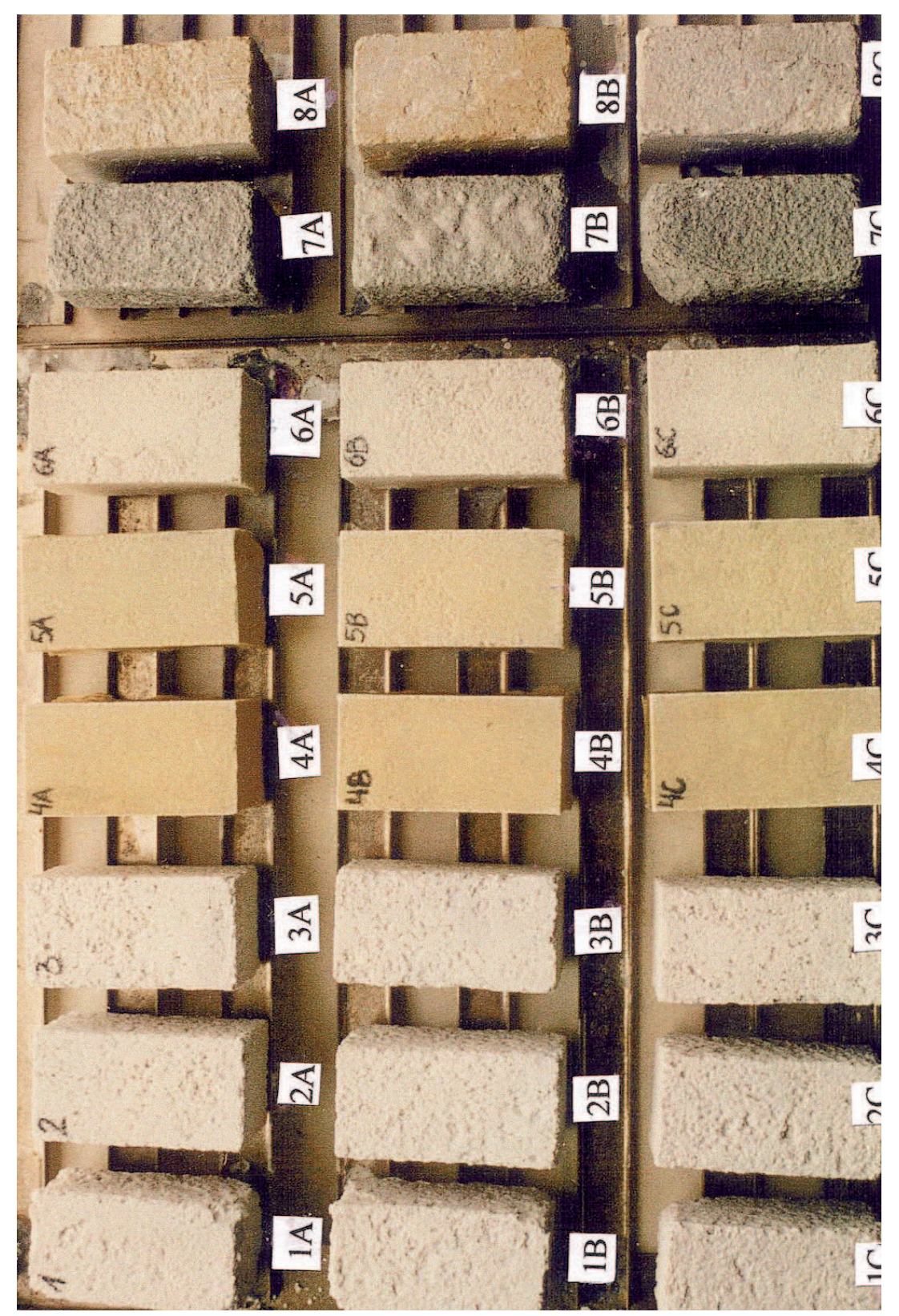

Il. 3. Test solny. Zaprawy cementowe po 4 cyklach, powierzchnie górne próbek:

1A, B, C - cem.:mączka kwarcowa:piasek $=1: 0,5: 7,5$

2A, B, C - cem.mączka kwarcowa:piasek $=1: 1,0: 7,0$

3A, B, C - cem.:mączka kwarcowa:piasek = 1:1,5:6,5

4A, B, C - żyw. epoksyd.:piasek $=1: 20$

5A, B, C - żyw. epoksyd.:piasek $=1: 30$

6A, B, C - PMM:piasek = 1:15

7A, B, C - piaskowiec Gotland

8A, B, C - piaskowiec Obernkirchen 


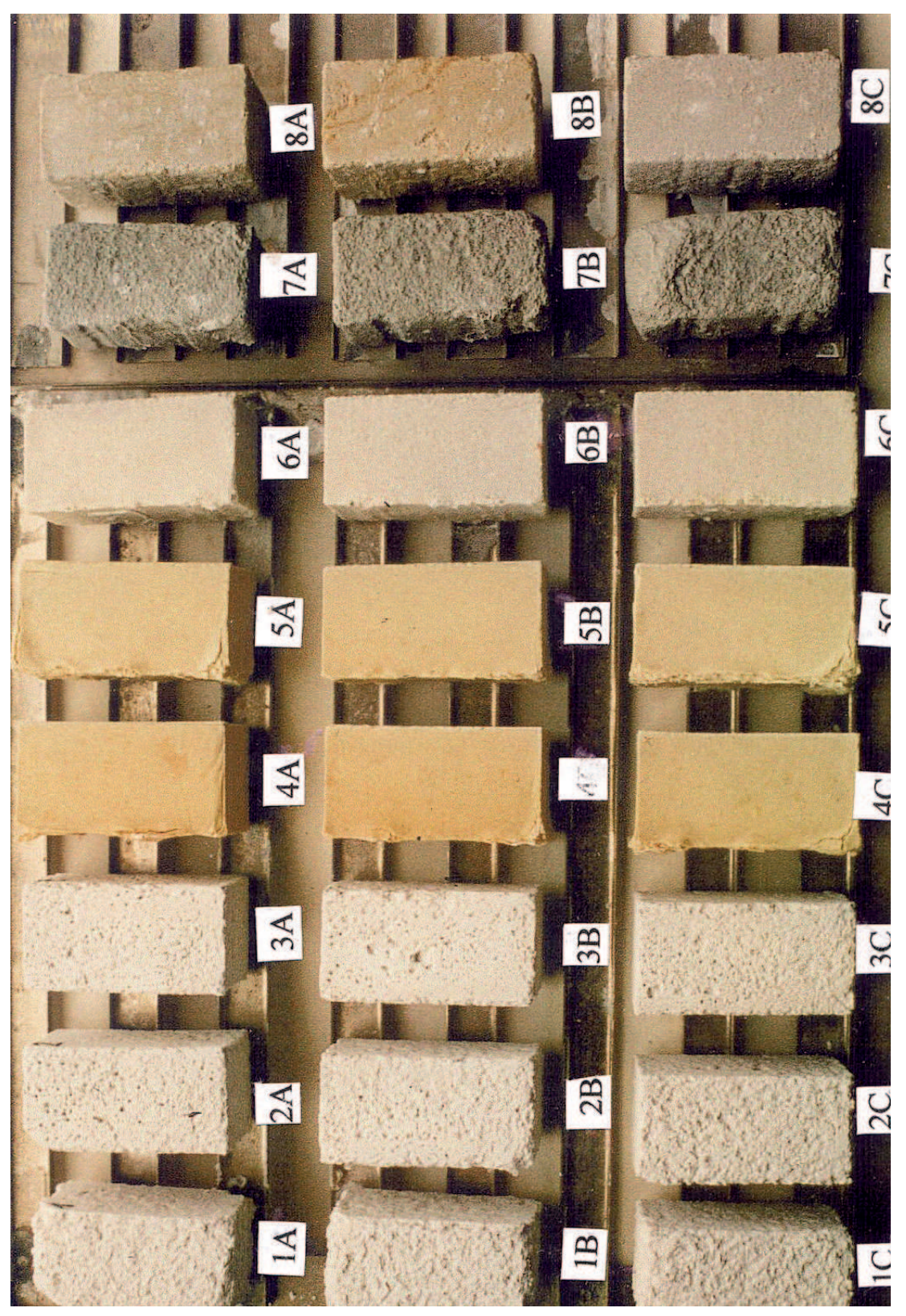

Il. 4. Test solny. Zaprawy cementowe po 4 cyklach, powierzchnie boczne próbek:

1A, B, C - cem.:mączka kwarcowa:piasek = 1:0,5:7,5

2A, B, C - cem.:mączka kwarcowa:piasek $=1: 1,0: 7,0$

3A, B, C - cem.:mączka kwarcowa:piasek $=1: 1,5: 6,5$

4A, B, C - żyw. epoksyd.:piasek $=1: 20$

5A, B, C - żyw. epoksyd.:piasek = 1:30

6A, B, C - PMM:piasek = 1:15

7A, B, C - piaskowiec Gotland

8A, B, C - piaskowiec Obernkirchen 


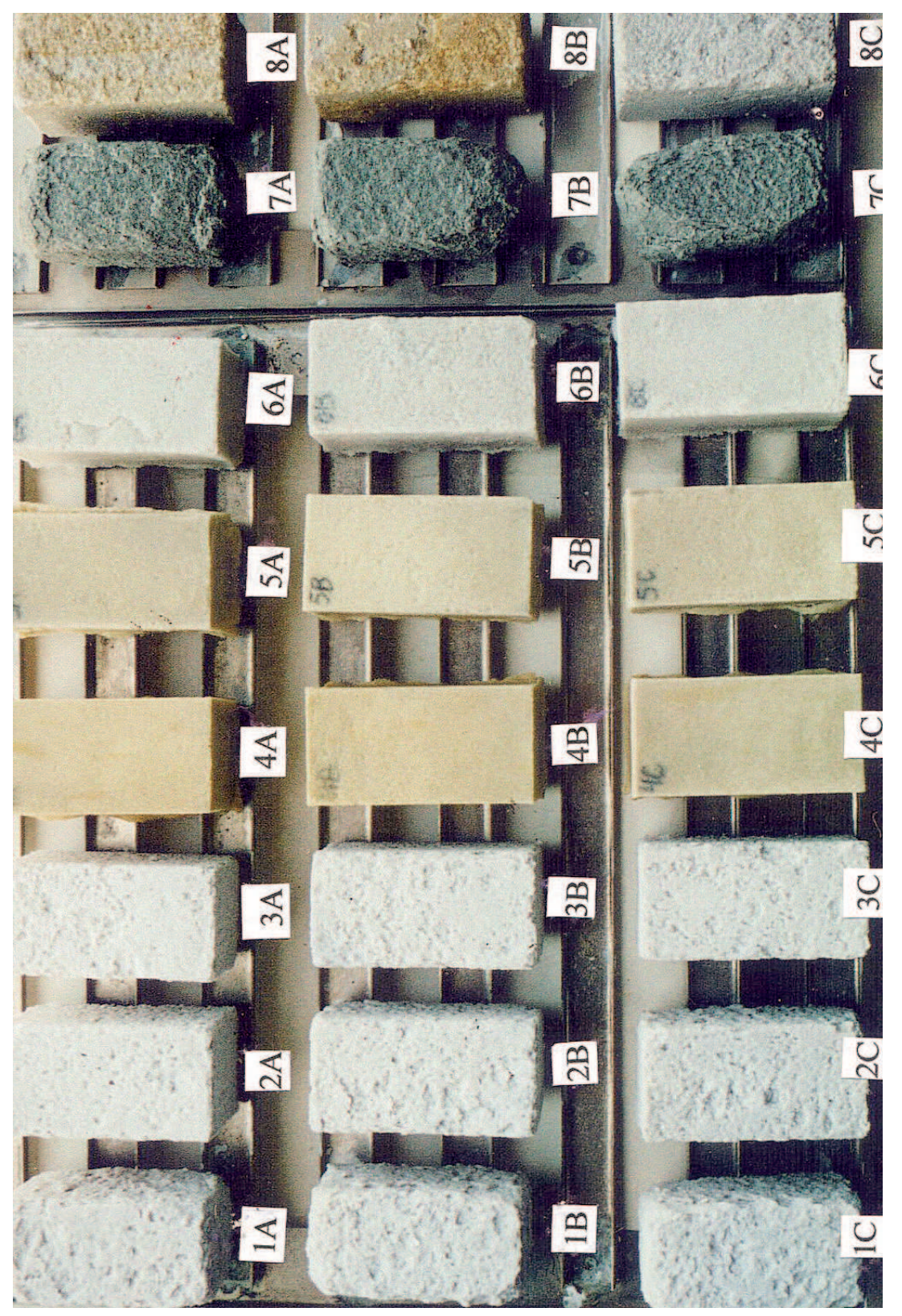

Il. 5. Test solny. Zaprawy cementowe po 5 cyklach, powierzchnie górne próbek:

1A, B, C - cem.mączka kwarcowa:piasek = 1:0,5:7,5

2A, B, C - cem.:mączka kwarcowa:piasek $=1: 1,0: 7,0$

3A, B, C - cem.:mączka kwarcowa:piasek $=1: 1,5: 6,5$

4A, B, C - żyw. epoksyd.:piasek $=1: 20$

5A, B, C - żyw. epoksyd.:piasek $=1: 30$

6A, B, C - PMM:piasek = 1:15

7A, B, C - piaskowiec Gotland

8A, B, C - piaskowiec Obernkirchen 


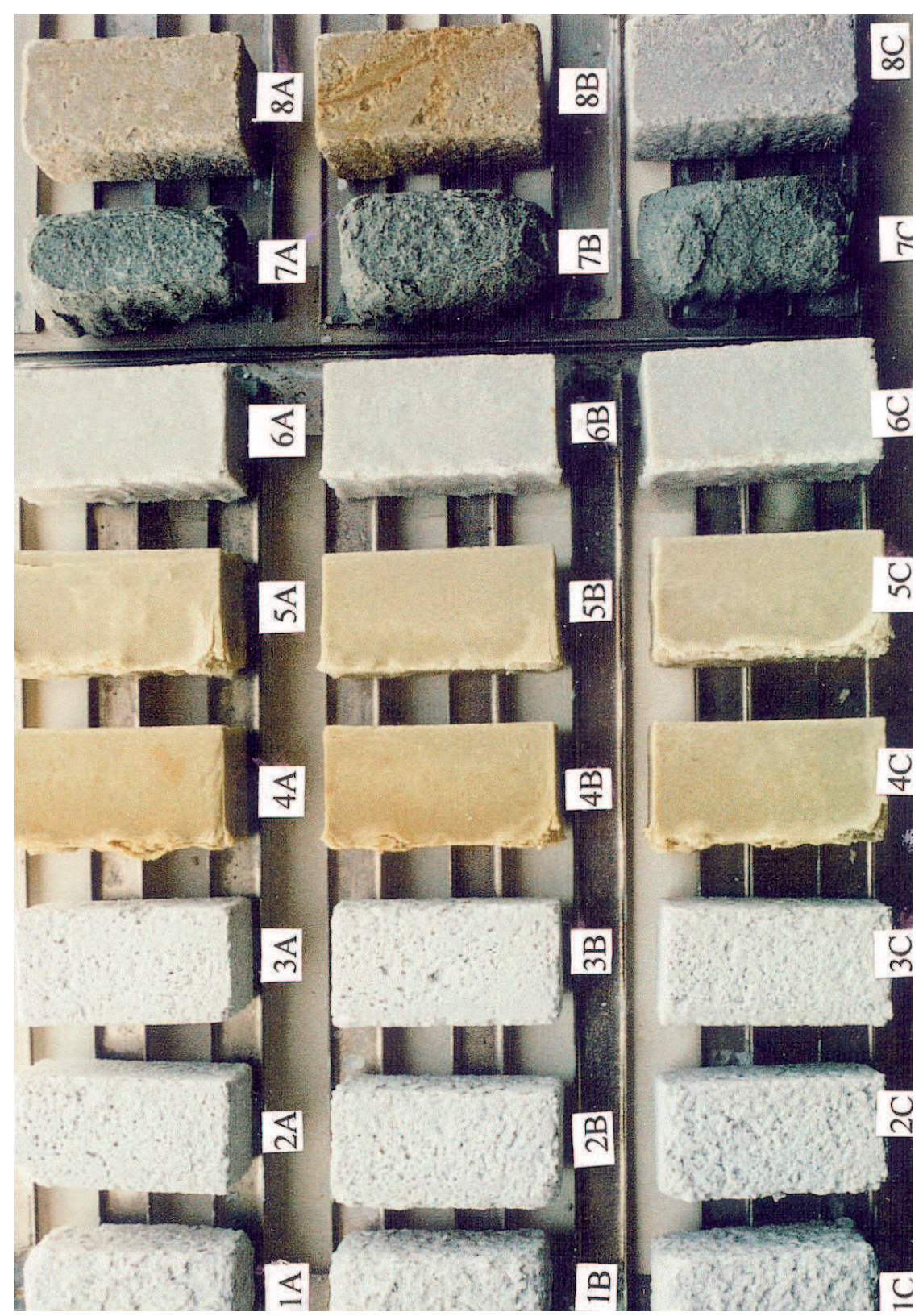

Il. 6. Test solny. Zaprawy cementowe po 5 cyklach, powierzchnie boczne próbek:

1A, B, C - cem.:mączka kwarcowa:piasek = 1:0,5:7,5

2A, B, C - cem.:mączka kwarcowa:piasek $=1: 1,0: 7,0$

3A, B, C - cem.:mączka kwarcowa:piasek $=1: 1,5: 6,5$

4A, B, C - żyw. epoksyd.:piasek $=1: 20$

5A, B, C - żyw. epoksyd.:piasek $=1: 30$

6A, B, C - PMM:piasek = 1:15

7A, B, C - piaskowiec Gotland

8A, B, C - piaskowiec Obernkirchen 


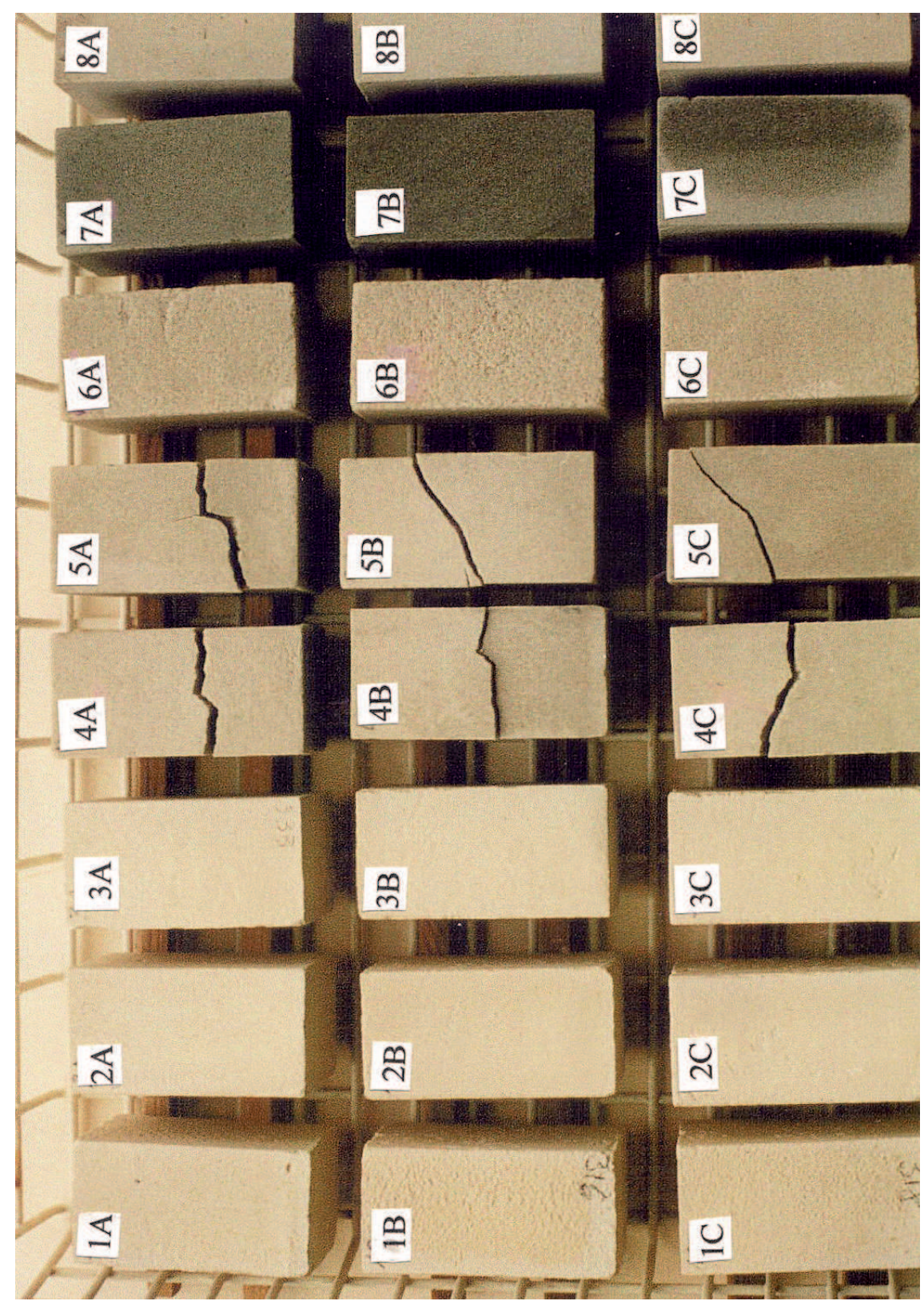

Il. 7. Odporność na zamrażanie zapraw cementowych, próbki po 20 cyklach:

1A, B, C - cem.:mączka kwarcowa:piasek = 1:0,5:7,5

2A, B, C - cem.:mączka kwarcowa:piasek $=1: 1,0: 7,0$

3A, B, C - cem.:mączka kwarcowa:piasek $=1: 1,5: 6,5$

4A, B, C - żyw. epoksyd.:piasek $=1: 20$

5A, B, C - żyw. epoksyd.:piasek = 1:30

6A, B, C - PMM:piasek = 1:15

7A, B, C - piaskowiec Gotland

8A, B, C - piaskowiec Obernkirchen 


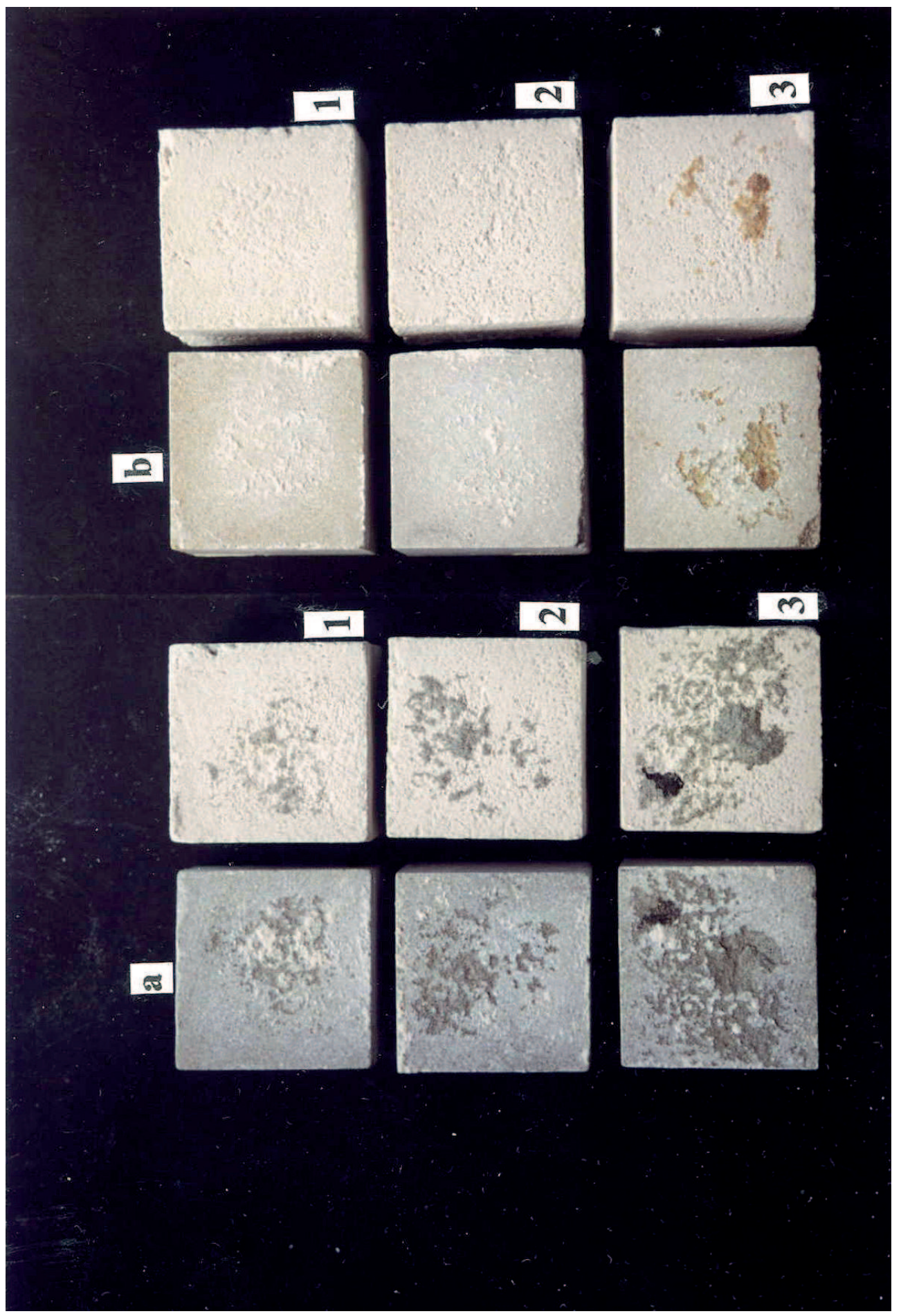

Il. 8. Przyczepność zapraw cementowych z mączką kwarcową do piaskowców Gotland (a) i Obernkirchen (b):

1 - cem.:mączka kwarcowa:piasek $=$ 1:0,5:7,5

2 - cem.:mączka kwarcowa:piasek $=1: 1,0: 7,0$

3 - cem.:mączka kwarcowa:piasek $=1: 1,5: 6,5$ 


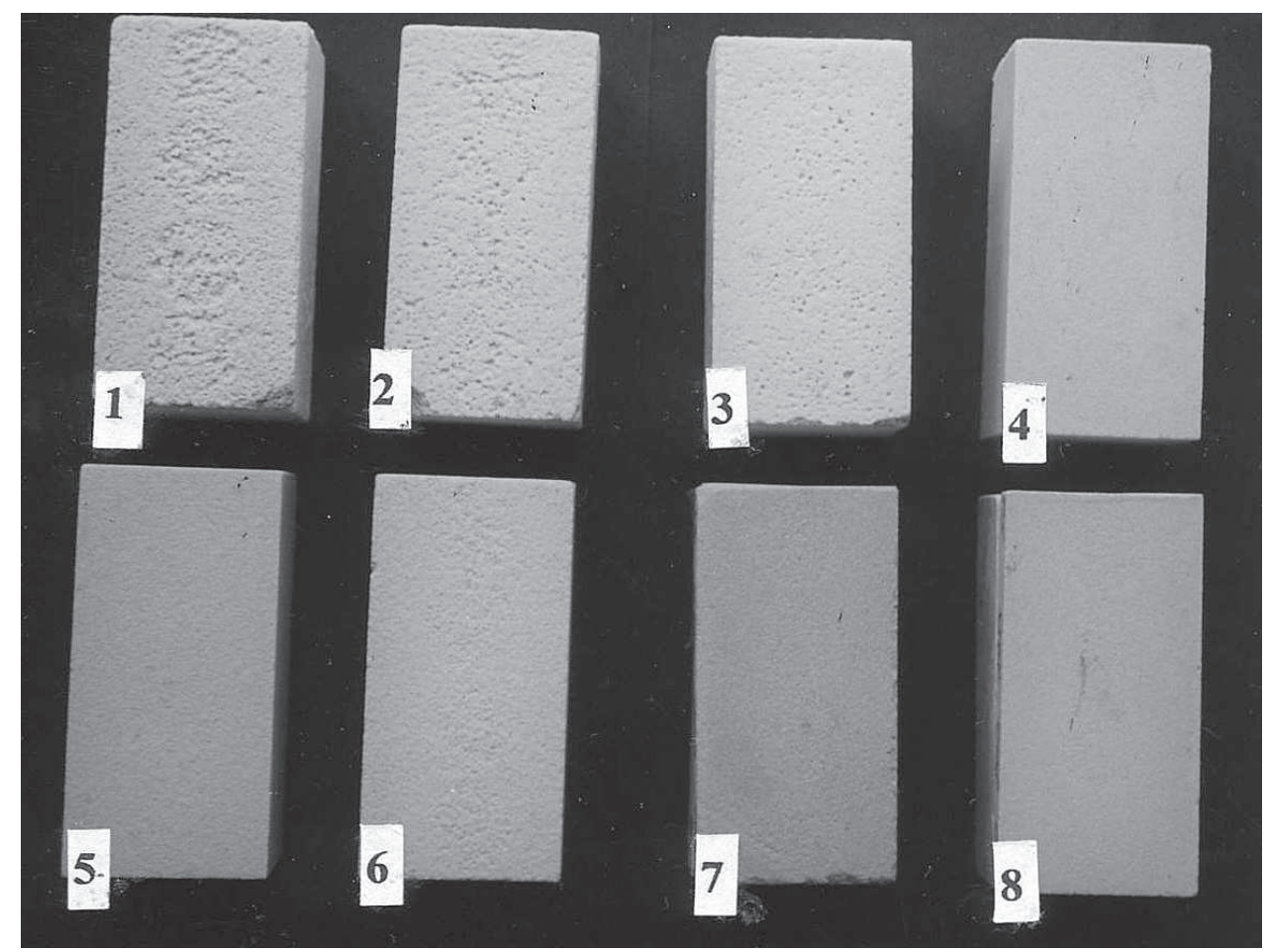

I1. 9. Odporność na ścieranie zapraw cementowych i piaskowców:

1 - cem.:mączka kwarcowa:piasek $=1: 0,5: 7,5$

2 - cem.:mączka kwarcowa:piasek $=1: 1,0: 7,0$

3 - cem.:mączka kwarcowa:piasek $=1: 1,5: 6,5$

4 - żyw. epoksyd.:piasek = 1:20

5 - żyw. epoksyd.:piasek $=1: 30$

6 - PMM:piasek = 1:15

7 - piaskowiec Gotland

8 - piaskowiec Obernkirchen 


\section{Summary}

\section{The research on technology of mortars imitation Gotland and Obernkirchen natural stones}

The Department of Conservation of Architectonic Elements and Details, Institute for the Study, Conservation and Restoration of Cultural Heritage NCU in Torun, working on commission of Deutsches Bergbau-Museum Zollern-Institut in Bochum (Germany) carried out research, that aimed for developing the technology of mortars, characterising with physical and chemical properties matching those of Gotland and Obernkirchen sandstones.

In the research mineral binders were used (Portland cements, hydratised and disperged lime) as well as organic ones (epoxy resin and polymethyl metacrylate). From among the aggregates the glass-makers' sand and ground sandstones were selected. The mortars were modified with addition of metakaolinite, colloidal silica, quartz and marble powder. Changing the proportion of the aggregates and binders and adding various amounts of modifying substances one tried to obtain mortars of the properties described above.

The criteria, that have been taken into consideration in the first place, were the capillary properties and compression resistance. If the mortars are to perform their protective function, their mechanical resistance should not exceed the resistance of sandstones, however it should guarantee their resistance to changing weather conditions (water, temperature).

From among numerous mortars with mineral binders that were tested, the postulated properties demonstrated cement mortars with sand ( $1: 4$ and $1: 5$ ), cement mortars with sand and colloidal silica (1:4:0,025), cement mortars with sand and hydratised lime ( $1: 4: 1)$, cement mortars with sand and quartz powder $40 \mu \mathrm{m}(1: 7: 1$ and $1: 6,5: 1,5)$. The last ones seem to be the most promising.

Taking into consideration the properties of mortars containing polymethyl metacrylate as a binder and sand as an aggregate one can propose their use (1:15) for filling cracks and crevices as well as for filling small, shallow injuries in the discussed sandstones. They have good adhesion and cure in layers of any thickness.

However, taking into consideration capillary properties, high porosity and absorbability of epoxy-resin mortars (resin:sand = from 1:20 to 1:30) one can 
postulate their application as desalinating plasters, particularly in cases, where the use of water-free materials is more appropriate (highly salinated artefacts, its susceptibility to water).

Both the polymethyl metacrylate and epoxy-resin mortars display - thanks to the addition of colloidal silica - very good hydrophilic properties and capillary absorb water much faster, than the examined sandstones. 